Prepared in cooperation with the Minnesota Pollution Control Agency

\title{
Potential Groundwater Recharge for the State of Minnesota Using the Soil-Water-Balance Model, 1996-2010
}

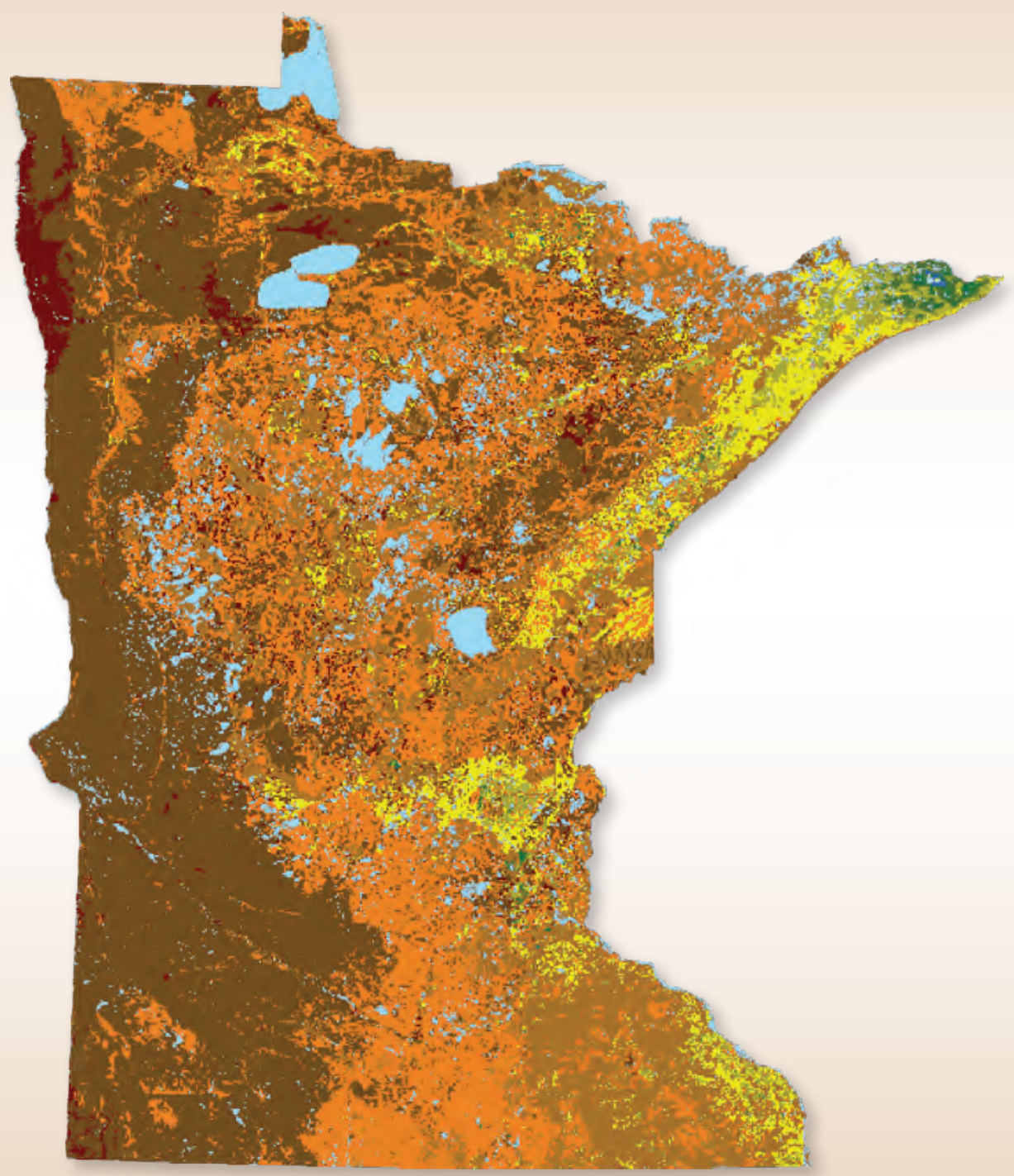

Scientific Investigations Report 2015-5038 
Cover. Map showing mean annual potential recharge rates from 1996-2010 based on results from the Soil-Water-Balance model for Minnesota. 


\section{Potential Groundwater Recharge for the State of Minnesota Using the Soil-Water- Balance Model, 1996-2010}

By Erik A. Smith and Stephen M. Westenbroek

Prepared in cooperation with the Minnesota Pollution Control Agency

Scientific Investigations Report 2015-5038 


\title{
U.S. Department of the Interior SALLY JEWELL, Secretary
}

\section{U.S. Geological Survey \\ Suzette M. Kimball, Acting Director}

\author{
U.S. Geological Survey, Reston, Virginia: 2015
}

For more information on the USGS - the Federal source for science about the Earth, its natural and living resources, natural hazards, and the environment—visit http://www.usgs.gov or call 1-888-ASK-USGS.

For an overview of USGS information products, including maps, imagery, and publications, visit http://www.usgs.gov/pubprod/.

Any use of trade, firm, or product names is for descriptive purposes only and does not imply endorsement by the U.S. Government.

Although this information product, for the most part, is in the public domain, it also may contain copyrighted materials as noted in the text. Permission to reproduce copyrighted items must be secured from the copyright owner.

Suggested citation:

Smith, E.A., and Westenbroek, S.M., 2015, Potential groundwater recharge for the State of Minnesota using the Soil-Water-Balance model, 1996-2010: U.S. Geological Survey Scientific Investigations Report 2015-5038, 85 p., http://dx.doi.org/10.3133/sir20155038.

ISSN 2328-0328 (online) 


\section{Contents}

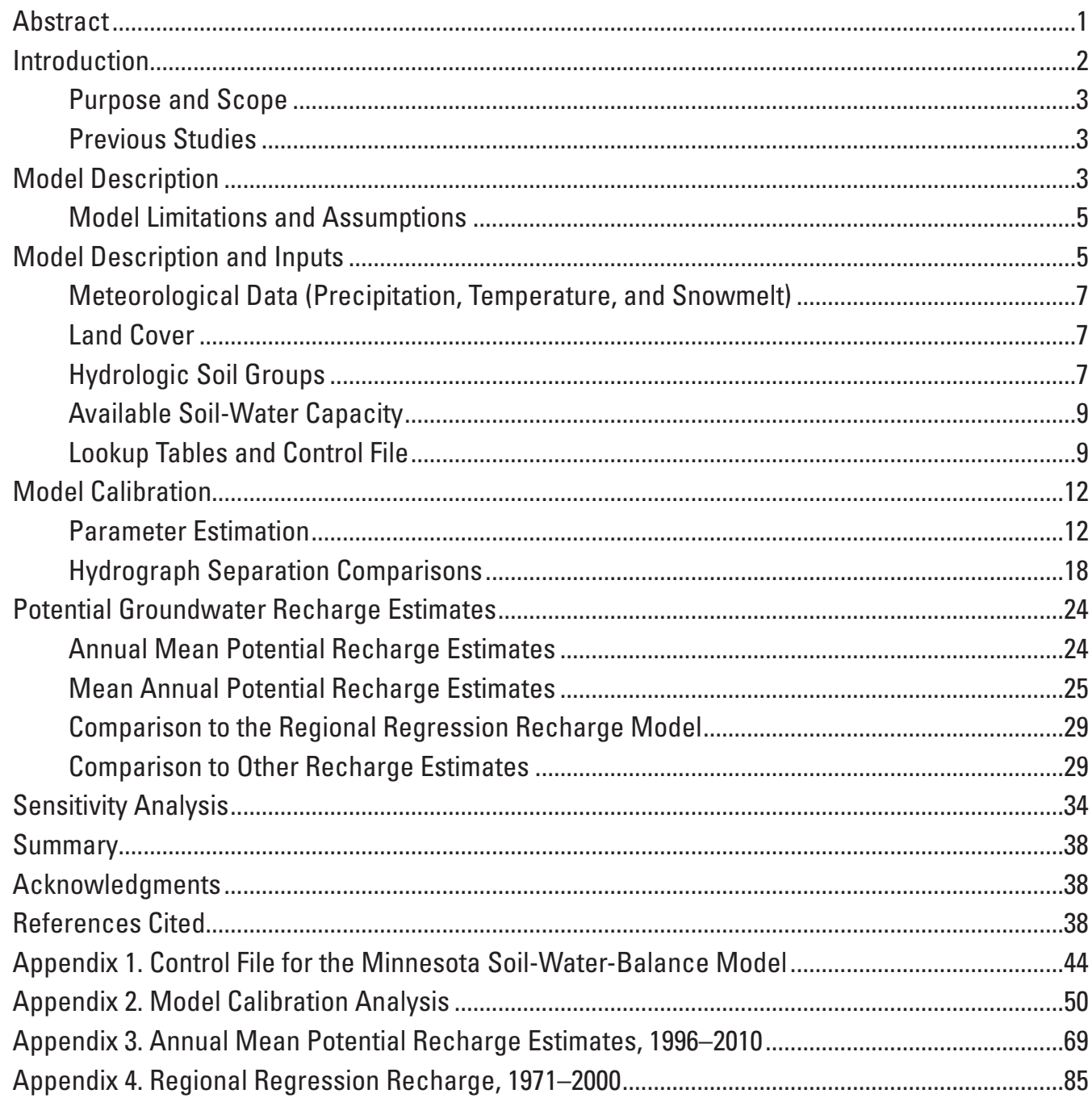

\section{Figures}

1. Diagram of the interaction between the Soil-Water-Balance model code and input

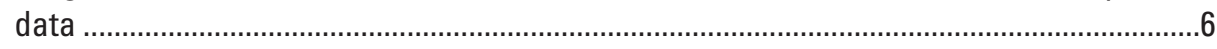

2. Map showing mean annual gross precipitation in Minnesota at a 1-kilometer

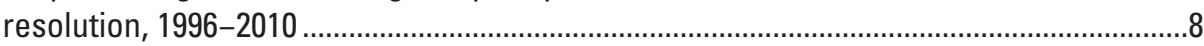

3. Map showing land cover in Minnesota at a 1-kilometer resolution, from the 2006

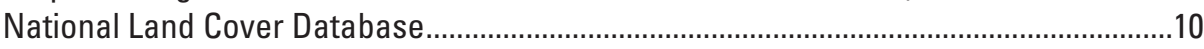

4. Map showing hydrologic soil groups in Minnesota at a 1-kilometer resolution based on the merged Soil Survey Geographic and the State Soil Geographic databases

5. Map showing available soil-water capacity in Minnesota at a 1-kilometer resolution based on the Geographic and the State Soil Geographic databases. 
6. Map showing watersheds with continuous streamflow data from 1996-2010 used for calibration of the Soil-Water-Balance model.

7. Graphs showing relation between 15 -year mean base-flow estimates from three different hydrograph separation techniques and the 15-year mean potential recharge estimates from the Soil-Water-Balance model for 35 selected watersheds, along with linear trendline...

8. Graphs showing relation between annual mean base-flow estimates from three different hydrograph separation techniques and the annual mean potential recharge estimates from the Soil-Water-Balance model for 35 selected watersheds, along with linear trendline

9. Map showing mean annual potential recharge rates from 1996-2010 based on results from the Soil-Water-Balance model for Minnesota

10. Map showing locations of point and regional recharge estimates referred to in text and table 9 .

11. Histogram of the mean annual potential recharge rates from the Soil-Water-Balance model from 1996-2010 for Minnesota...

12. Graph showing relation between mean annual gross precipitation and the mean annual potential recharge estimates from the Soil-Water-Balance model for the overall calibration period (1996-2010) for the 35 selected watersheds used for model calibration

13. Map showing mean annual potential recharge estimates from the Soil-Water-Balance model, shown as a percentage of mean annual gross precipitation from 1996-2010

14. Map showing difference between mean annual potential recharge estimates from the Soil-Water-Balance model for 1996-2010 and recharge estimates from the regional regression recharge model for 1971-2000.

3-1. Map showing annual mean potential recharge for 1996, based on results from the Minnesota Soil-Water-Balance model

3-2. Map showing annual mean potential recharge for 1997, based on results from the Minnesota Soil-Water-Balance model

3-3. Map showing annual mean potential recharge for 1998, based on results from the Minnesota Soil-Water-Balance model

3-4. Map showing annual mean potential recharge for 1999, based on results from the Minnesota Soil-Water-Balance model

3-5. Map showing annual mean potential recharge for 2000, based on results from the Minnesota Soil-Water-Balance model

3-6. Map showing annual mean potential recharge for 2001, based on results from the Minnesota Soil-Water-Balance model

3-7. Map showing annual mean potential recharge for 2002, based on results from the Minnesota Soil-Water-Balance model

3-8. Map showing annual mean potential recharge for 2003, based on results from the Minnesota Soil-Water-Balance model

3-9. Map showing annual mean potential recharge for 2004, based on results from the Minnesota Soil-Water-Balance model

3-10. Map showing annual mean potential recharge for 2005, based on results from the Minnesota Soil-Water-Balance model

3-11. Map showing annual mean potential recharge for 2006, based on results from the Minnesota Soil-Water-Balance model

3-12. Map showing annual mean potential recharge for 2007, based on results from the Minnesota Soil-Water-Balance model 
3-13. Map showing annual mean potential recharge for 2008, based on results from the Minnesota Soil-Water-Balance model

3-14. Map showing annual mean potential recharge for 2009, based on results from the Minnesota Soil-Water-Balance model

3-15. Map showing annual mean potential recharge for 2010, based on results from the Minnesota Soil-Water-Balance model

4-1. Map showing mean annual recharge rates to surficial materials in Minnesota from 1971-2000 based on the regional regression recharge model of Delin and others (2007)

\section{Tables}

1. Distribution of land cover in Minnesota based on the 2001 National Land Cover Database and the 2006 National Land Cover Database...

2. Distribution of soils in Minnesota based on the Soil Survey Geographic and the State Soil Geographic databases

3. Lookup table for the Soil-Water-Balance model, corresponding land cover to runoff curve number (by hydrologic soil group), maximum recharge rate (by hydrologic soil group), interception storage (growing season/dormant season), and root-zone depth (by hydrologic soil group).

4. Mean annual base-flow estimates from 1996-2010 using 3 hydrograph separation techniques for the watersheds of 35 streamgages used in model calibration in comparison to the estimated potential recharge rates for the same period from the Soil-Water-Balance model.

5. Distribution of land cover in Minnesota for the 35 selected watersheds and for the State, based on the 2006 National Land Cover Database...

6. Absolute mean error and root mean square error between the annual mean potential recharge estimate from the Soil-Water-Balance model and the annual mean base-flow estimates from the three hydrograph separation techniques for the overall calibration period (1996-2010) for 35 selected watersheds

7. Nash-Sutcliffe model efficiency coefficient between annual mean base-flow estimates from three different hydrograph separation techniques and the annual mean potential recharge estimate from the Soil-Water-Balance model.

8. Total area of active cells in Soil-Water-Balance model and mean annual potential recharge estimates, by land-cover class and hydrologic soil group, from 1996-2010.

9. Comparison of selected point and regional recharge estimates to potential recharge estimates from the Soil-Water-Balance model...

10. Summary of relative percent sensitivity analysis from the base value in the lookup table of the calibrated Soil-Water-Balance model. Each parameter was separately adjusted by plus or minus 20 percent to calculate the relative percent sensitivity........35

11. Summary of relative percent sensitivity analysis for precipitation, daily minimum air temperature, and daily maximum air temperature from the base value used in the control file for the Soil-Water-Balance model.

2-1. Annual mean base-flow estimates rates from 1996-2010 using three hydrograph separation techniques for the 35 streamgages used in model calibration analysis in comparison to the estimated annual potential recharge rates for the same period from the Soil-Water-Balance model. 


\section{Conversion Factors}

Inch/Pound to International System of Units (primary units used within report)

\begin{tabular}{|c|c|c|}
\hline Multiply & By & To obtain \\
\hline \multicolumn{3}{|c|}{ Length } \\
\hline inch (in.) & 2.54 & centimeter $(\mathrm{cm})$ \\
\hline inch (in.) & 25.4 & millimeter (mm) \\
\hline foot $(\mathrm{ft})$ & 0.3048 & meter $(\mathrm{m})$ \\
\hline mile (mi) & 1.609 & kilometer (km) \\
\hline \multicolumn{3}{|c|}{ Flow rate } \\
\hline inch per hour (in/h) & 0.0254 & meter per hour $(\mathrm{m} / \mathrm{h})$ \\
\hline inch per year (in/yr) & 25.4 & millimeter per year $(\mathrm{mm} / \mathrm{yr})$ \\
\hline
\end{tabular}

International System of Units to Inch/Pound (used for spatial data and some model input values)

\begin{tabular}{lll}
\hline \multicolumn{1}{c}{ Multiply } & By & \multicolumn{1}{c}{ To obtain } \\
\hline millimeter $(\mathrm{mm})$ & Length & \\
meter $(\mathrm{m})$ & 0.03937 & inch (in.) \\
meter $(\mathrm{m})$ & 3.281 & foot (ft) \\
kilometer $(\mathrm{km})$ & 39.37 & mile (mi) \\
\hline & 0.6214 & \\
\hline hectare (ha) & Area & acre \\
square kilometer $\left(\mathrm{km}^{2}\right)$ & 2.471 & square mile $\left(\mathrm{mi}^{2}\right)$ \\
\hline
\end{tabular}

\section{Supplemental Information}

Temperature in degrees Celsius $\left({ }^{\circ} \mathrm{C}\right)$ may be converted to degrees Fahrenheit $\left({ }^{\circ} \mathrm{F}\right)$ as follows:

${ }^{\circ} \mathrm{F}=\left(1.8 \times{ }^{\circ} \mathrm{C}\right)+32$

\section{Datum}

Horizontal coordinate information is referenced to the North American Datum of 1983 (NAD 83). 


\section{Abbreviations}

$>$

$<$

AME

APWL

ASCII

BFI

ET

GDD

GIS

Minn.

NCDC

NLCD

NOAA

NRCS

NSE

RMSE

RRR

SSURGO

STATSGO

SWB

TCMA

USDA

USGS greater than

less than

absolute mean error

accumulated potential water loss

American Standard Code for Information Interchange

base-flow index

evapotranspiration

growing degree days

geographic information system

Minnesota

National Climatic Data Center

National Land Cover Database

National Oceanic and Atmospheric Administration

Natural Resources Conservation Service

Nash-Sutcliffe model efficiency coefficient

root mean square error

regional regression recharge

Soil Survey Geographic [database]

State Soil Geographic [database]

Soil-Water-Balance

Twin Cities Metropolitan Area

United States Department of Agriculture

U.S. Geological Survey

\section{Variables}

$\begin{array}{ll}\Delta \text { soil moisture } & \text { change in soil moisture } \\ E T & \text { evapotranspiration } \\ n & \text { number of years } \\ \bar{O} & \text { mean of the observed data } \\ O_{i} & \text { observed value } \\ P & \text { precipitation } \\ \bar{P} & \text { mean of the predicted data } \\ P_{i} & \text { predicted (simulated) value } \\ P E & \text { potential evapotranspiration } \\ P-P E & \text { precipitation minus potential evapotranspiration } \\ R^{2} & \text { coefficient of determination }\end{array}$





\title{
Potential Groundwater Recharge for the State of Minnesota Using the Soil-Water-Balance Model, 1995-2010
}

\author{
By Erik A. Smith and Stephen M. Westenbroek
}

\section{Abstract}

Groundwater recharge is one of the most difficult components of a water budget to ascertain, yet is an important boundary condition necessary for the quantification of water resources. In Minnesota, improved estimates of recharge are necessary because approximately 75 percent of drinking water and 90 percent of agricultural irrigation water in Minnesota are supplied from groundwater. The water that is withdrawn must be supplied by some combination of (1) increased recharge, (2) decreased discharge to streams, lakes, and other surface-water bodies, and (3) removal of water that was stored in the system. Recent pressure on groundwater resources has highlighted the need to provide more accurate recharge estimates for various tools that can assess the sustainability of long-term water use. As part of this effort, the U.S. Geological Survey, in cooperation with the Minnesota Pollution Control Agency, used the Soil-Water-Balance model to calculate gridded estimates of potential groundwater recharge across Minnesota for 1996-2010 at a 1-kilometer (0.621-mile) resolution. The potential groundwater recharge estimates calculated for Minnesota from the Soil-Water Balance model included gridded values (1-kilometer resolution) of annual mean estimates (that is, the means for individual years from 1996 through 2010) and mean annual estimates (that is, the mean for the 15-year period 1996-2010).

The Soil-Water-Balance model uses a modified Thornthwaite-Mather soil-water-balance approach, with components of the soil-water balance calculated on a daily basis. A key advantage of this approach includes the use of commonly available geographic information system data layers that incorporate land cover, soil properties, and daily meteorological data to produce temporally and spatially variable gridded estimates of potential recharge. The Soil-Water-Balance model was calibrated by using a combination of parameter estimation techniques, making manual adjustments of model parameters, and using parameter values from previously published SoilWater-Balance models. Each calibration simulation compared the potential recharge estimate from the model against base-flow estimates derived from three separate hydrograph separation techniques. A total of 35 Minnesota watersheds were selected for the model calibration.

Meteorological data necessary for the model included daily precipitation, minimum daily temperature, and maximum daily temperature. All of the meteorological data were provided by the Daymet dataset, which included daily continuous surfaces of key climatological data. Land-cover data were provided by the 2001 and 2006 National Land Cover Database: the 2001 classification was used from 1994 through 2003, and the 2006 classification was used from 2004 through 2010. Soil data used in the model included hydrologic soils group and the available soil-water capacity. These soil data were obtained from the Natural Resources Conservation Service Soil Survey Geographic (SSURGO) database and the State Soil Geographic (STATSGO) database.

The statewide mean annual potential recharge rate from 1996-2010 was 4.9 inches per year. Potential recharge estimates increased from west to east across Minnesota. The mean annual potential recharge estimates across Minnesota at a 1-km resolution for the overall simulation period (1996-2010) ranged from less than 0.1 to 17.8 inches per year. Some of the lowest potential recharge rates for the simulation period were in the Red River of the North Basin of northwestern Minnesota, and generally were between 1.0 and 1.5 inches per year. The highest potential recharge rates were in northeastern Minnesota and the Anoka Sand Plain in central Minnesota. Eightyeight percent of the potential recharge rates (by grid cell) were between 2 and 8 inches per year from 1996-2010. Only about 3 percent of all the potential recharge estimates (by grid cell) were less than 2 inches per year, and 9 percent of estimates were greater than 8 inches per year.

On an annual basis, however, potential recharge rates were as high as 27.2 inches per year. The highest annual mean recharge estimate across the State was for 2010, and the lowest mean recharge estimate was for 2003. Although precipitation variability partially explained the annual differences in potential recharge estimates, precipitation alone did not account for these differences, and other factors such as antecedent moisture conditions likely were important. Also, because precipitation gradients across the State can vary from year to year, the dominant land-cover class and hydrologic soil 
group combinations for a particular region had a large effect on the resulting potential recharge value. During 1996-2010, April had the greatest monthly mean potential recharge compared to all other months, accounting for a mean of 30 percent of annual potential recharge in this single month.

\section{Introduction}

Groundwater recharge is one of the most important boundary conditions necessary for the development of water budgets. Groundwater recharge is a natural component of the hydrologic cycle and replenishes groundwater that has been withdrawn for various anthropogenic uses. Because groundwater commonly discharges to streams, lakes, and other surface-water bodies, groundwater recharge has a connection to the sustainability of water resources and their ecological health. However, recharge is difficult to estimate because recharge varies spatially and temporally in response to a variety of factors such as climate, precipitation intensity and duration, evapotranspiration, overland runoff patterns, land-cover changes, aquifer properties, soil properties, and geomorphology (Healy and Scanlon, 2010). On a spatial scale, point estimates of recharge are not appropriate for regionalscale models, and on a temporal scale, multiyear hydrologic assessments based on static recharge estimates can misrepresent the overall water budget. For groundwater modelers, a simple approach is to assume that a fixed percentage of precipitation becomes recharge, although this approach does not take antecedent moisture conditions into consideration. Yet another approach is to use recharge as a calibration parameter in a model, adjusting the recharge rates until the measured water-table values match the simulated values. However, using a physically based recharge boundary condition rather than using recharge as a calibration parameter has been shown to improve groundwater models (Jyrkama and others, 2002) and underscores the importance of determining independent recharge rates.

Numerous techniques exist to estimate variable recharge rates. Example techniques include water-table fluctuation methods (Healy and Cook, 2002; Crosbie and others, 2005), Darcian methods (Nimmo and others, 1994), groundwater age dating (McMahon and others, 2011), recession curve displacement methods such as the RORA program (Rutledge, 1998), and water budget models (Vaccaro, 2007). Overall, dozens of possible recharge estimation methods exist, so choosing an appropriate technique can be difficult (Scanlon and others, 2002). Important considerations for the appropriate recharge estimation method include the time scale, the need for static or transient estimates, spatial scale of the recharge estimates, availability of the necessary data, and the ease of use of the recharge estimation method or model. In regards to the spatial scale, a balance of the local- and regional-scale recharge estimates must be reached, because local estimates (scale from submeters to hectares; feet to acres) generally will not be appropriate for the watershed scale, whereas regional recharge estimates (scale between 10 and 1,000 square kilometers [km]; thousands of acres to hundreds of square miles) do not capture local variability (Healy and Scanlon, 2010).

In Minnesota, improved estimates of recharge rates are important because the State is dependent on groundwater resources. Approximately 75 percent of drinking water and 90 percent of agricultural irrigation water in Minnesota is supplied from groundwater (Minnesota Department of Natural Resources, 2014). The water that is withdrawn must be supplied by some combination of (1) increased recharge, (2) decreased discharge to streams, lakes, and other surfacewater bodies, and (3) removal of water that was stored in the system. With such a heavy reliance on groundwater, proper accounting of groundwater resources is critical. As part of any assessment to determine groundwater resources available for withdrawal, reliable recharge estimates are helpful in determining the sustainable pumping rate out of an aquifer (Zhou, 2009). However, as pointed out by Bredehoeft (1997), it is important to note that using groundwater recharge as approximately equal to the safe yield of sustainable groundwater developments (for example, groundwater withdrawals for consumptive uses) can be fallacious. As noted by Alley (2006), even small changes in total groundwater storage can cause streamflow depletion.

Recent pressure on groundwater resources in Minnesota has highlighted the need to provide more accurate recharge estimates for various tools that can assess the sustainability of long-term water use. As part of this effort, the U.S. Geological Survey (USGS), in cooperation with the Minnesota Pollution Control Agency, used the Soil-Water-Balance (SWB) model (Westenbroek and others, 2010) to calculate mean gridded estimates of potential groundwater recharge across Minnesota from 1996-2010 at a 1-kilometer (0.621-mile) resolution. Potential recharge is infiltrating water that may or may not reach the water table because of unsaturated-zone processes or diversion before reaching the water table (Scanlon and others, 2002). In this report, the term "recharge" in context to any estimate determined by using the SWB model is synonymous with potential recharge. The SWB model is ideal for estimating recharge because the water table is fairly shallow across most of the State, so water that infiltrates beyond the root zone will likely recharge the aquifer.

The SWB model is based on a modified ThornthwaiteMather soil-water-balance approach (Thornthwaite and Mather, 1955, 1957) that calculates water balance components at a daily time step (Westenbroek and others, 2010). This approach uses commonly available geographic information system (GIS) data layers that incorporate land cover, soil properties, and daily meteorological data to produce temporally and spatially variable gridded estimates of recharge. 


\section{Purpose and Scope}

The purpose of this report is to document the development of potential recharge estimates for Minnesota using the SWB model (Westenbroek and others, 2010) at a 1-km resolution. The statewide recharge estimates were calibrated by using a combination of parameter estimation (Doherty, 2010), manual adjustments of model parameters, and parameter values from previously published SWB recharge models (Metropolitan Council, 2013; Westenbroek and others, 2010; Stanton and others, 2011; Masterson and others, 2013). Calibration simulations were completed using assumptions of steady-state conditions, in which no pumping was considered. Each calibration simulation compared the potential recharge estimate of the model against base-flow estimates derived from three separate hydrograph separation techniques. A total of 35 Minnesota watersheds were selected for the model calibration. A sensitivity analysis also was done to better understand the response of the model to some of its most important parameters and inputs. Limitations of the model also are described. Although recharge estimates and most model inputs are in units of inch/pound, spatial data such as model grid spacing and some model inputs use the International System of Units.

\section{Previous Studies}

Delin and others (2007) estimated the mean annual recharge to surficial materials from 1971 to 2000 for the State of Minnesota. This regional regression recharge (RRR) model regionalized RORA watershed-scale recharge estimates (Rutledge, 1998) based on a regression model that incorporated soil and meteorological information. Delin and others (2007) and Lorenz and Delin (2007) provided additional details on the approach used to estimate recharge. Instead of tracking the water balance components at a daily time step, the regression included precipitation and growing degree days (GDD), a commonly used measure of heat accumulation, to estimate the net precipitation available for recharge instead of a direct measure of evapotranspiration (ET). Although the GDD are a primary factor in estimating ET, the GDD do not account for the effects of land cover and soil characteristics on ET. Delin and others (2007) compared the RRR estimates to RORA watershed-scale recharge estimates as well as to three local-scale methods (unsaturated-zone water balance, watertable fluctuations using three approaches, and age dating of groundwater).

A study by Kanivetsky (1979) used as many as three independent recharge calculation methods for each of 39 watersheds in Minnesota. The three methods used for each watershed, where data were available, were base-flow separation from streamflow, water-table fluctuations from observation wells, and 30-day low-flow characterization of streamflow. For each watershed, a synthesis of the three methods was scaled up to the watershed-scale and compared. The final recharge rates for each watershed were used to estimate available groundwater resources; however, a separate recharge map of recharge across Minnesota was not published.

Wolock (2003a) estimated the mean annual natural groundwater recharge in the conterminous United States, including all of Minnesota, as a 1-km resolution (grid) dataset. This $1-\mathrm{km}$ grid was created by multiplying a grid of base-flow index (BFI) values by a grid of mean annual runoff values derived from a mean annual runoff contour map for 1951-80. Mean annual runoff is long-term mean streamflow expressed on a per-unit-area basis. The BFI grid used to compute groundwater recharge was interpolated from BFI point values estimated for USGS streamgages (Wolock, 2003b). The BFI point values were computed by using the automated hydrograph separation computer program called BFI (Wahl and Wahl, 2014).

Other studies have produced recharge estimates for parts of Minnesota; examples include Arnold and others (2000), Ruhl and others (2002), Neff and others (2006), and Metropolitan Council (2013). Arnold and others (2000) was limited to the USGS 8-digit watershed scale for the Upper Mississippi River Basin and represented recharge for a fixed period of time. Ruhl and others (2002) estimated recharge rates across broad areas of the seven-county Twin Cities Metropolitan Area (TCMA) using three different techniques: recharge as a percentage of precipitation, recharge based on streamflowrecession displacement, and recharge as determined by a watershed characteristics method. Neff and others (2006) estimated recharge for parts of northeast Minnesota adjacent to Lake Superior by applying base-flow estimates calculated from gaged watersheds equally to the entire watershed area. The Metropolitan Council (2013) used the SWB model to generate recharge estimates for the period of 1988 to 2011 for a more expansive 11-county TCMA.

\section{Model Description}

The SWB model uses a modified Thornthwaite-Mather soil-water-balance approach (Thornthwaite and Mather, $1955,1957)$, calculated on a daily basis, to estimate potential recharge. These estimates can be imported into regional groundwater-flow models or other hydrologic assessments where accurate recharge estimates are necessary. Also, the gridded approach of the SWB model allows for potential recharge estimates to be re-scaled to match the resolution of the groundwater-flow model.

A primary feature of the SWB model is the use of the U.S. Department of Agriculture (USDA) Natural Resources Conservation Service (NRCS) curve number rainfall-runoff relation, also known as the curve number method (Cronshey and others, 1986). Beyond its simplicity and convenience, the curve number method is well established in hydrologic practice and has been used in numerous applications worldwide (Ponce and Hawkins, 1996). Only one unique parameter, the curve number (also known as the runoff curve number), is 
Potential Groundwater Recharge for the State of Minnesota Using the Soil-Water-Balance Model, 1996-2010

necessary for each combination of land-use class and soil type. Most importantly, the curve number rainfall-runoff relations have been shown to perform reasonably well for the central United States (Hjelmfelt, 1991).

The SWB model uses a soil-water accounting method to calculate potential recharge for each grid cell in the model domain separately (Westenbroek and others, 2010). Computation of water-budget components relies on relations between surface runoff, land cover, hydrologic soil group, maximum soil-water capacity, ET estimates, and temperature. Within the soil-water-balance approach, potential recharge is calculated within each grid cell of the model domain based on the difference between sources (precipitation, snowmelt, inflow), sinks (interception, outflow, ET), and change in soil moisture ( $\Delta$ soil moisture) (equation 1):

$$
\begin{gathered}
\text { potential recharge }=(\text { precipitation }+ \text { snowmelt }+ \text { inflow }) \\
-(\text { interception }+ \text { outflow }+E T)-\Delta \text { soil moisture }
\end{gathered}
$$

Each of the water-budget components in equation 1 is handled by one or more modules within the SWB model. For the potential sources, precipitation and snowmelt are described in the subsection "Meteorological Data (Precipitation, Temperature, and Snowmelt)." The inflow component (from adjacent cells) in the model was not included because surface routing was turned off based on the large grid size (1-km). Of the sinks, ET is handled by the model without user intervention, and only the Hargreaves-Samani ET method (Hargreaves and Samani, 1985) is available for simulations with spatially varying gridded data such as those used in the Minnesota SWB model. Interception is defined as the portion of precipitation intercepted by the plant canopy and lost to ET; it is controlled by user-defined values for each unique land-cover class in a lookup table. Outflow from each grid cell, also known as surface runoff, is calculated by the NRCS curve number rainfall-runoff relation (Cronshey and others, 1986). Additional theoretical and background details on outflow and the other hydrologic components are detailed in Westenbroek and others (2010).

Changes in soil moisture ( $\Delta$ soil moisture $)$ are tabulated by the soil-water-balance methods published by Thornthwaite (1948) and Thornthwaite and Mather $(1955,1957)$ by using intermediary values. These changes in soil moisture are tabulated on a daily time step. The intermediary values important to understand for the Minnesota SWB model include precipitation $(P)$ minus potential evapotranspiration $(P E)$, also known as $P-P E$, and the accumulated potential water loss (APWL). The calculation of intermediary values of $P-P E$ is the first step in calculating a new soil moisture value, where negative $P-P E$ values represent potential water deficiencies in the soil moisture and positive $P-P E$ values represent a potential water surplus in the soil moisture. The APWL is a running sum of the daily $P-P E$ values when $P-P E$ is negative, and represents the unsatisfied $P E$ to which the soil has been subjected. During the first days in which $P-P E$ is negative, soils typically yield water more easily than subsequent days. However, as the APWL continues to increase, soil moisture is less readily given up. The process of yielding water from a soil profile is a nonlinear relation between soil moisture and APWL, and was described in detail by Thornthwaite and Mather (1957) in a series of tables. These Thornthwaite-Mather soil-water retention tables are incorporated into the SWB model code.

To calculate the new soil moisture value when $P-P E$ is negative, the incorporated Thornthwaite-Mather soil-water retention table is used to match the current APWL to a soil moisture value. During days in which $P-P E$ is positive, the $P-P E$ term is added directly to the soil moisture value from the previous day. Until the soil moisture value reaches the maximum soil-water capacity, the Thornthwaite-Mather soilwater retention table is consulted to back-calculate an updated, reduced APWL value. Once the maximum soil-moisture capacity is exceeded, the soil-moisture value is capped at the maximum soil-water capacity value, the excess water beyond the capped maximum value becomes potential recharge and the APWL is reset to zero. In some cases, if the potential recharge exceeds a user-defined maximum recharge rate, any excess potential recharge beyond the maximum recharge rate is converted to "rejected recharge" and is removed from further consideration.

Precipitation within the SWB model is tracked on a daily basis, and the model determines whether it falls as rain or snow. If precipitation falls on a day when the daily mean air temperature minus one-third the difference between the daily maximum and minimum air temperature is less than or equal to the freezing point of water, the precipitation falls as snow (Dripps, 2003). Snowmelt computed by the model is based on a temperature-index method (Dripps and Bradbury, 2007) as follows: 1.5 millimeters (mm; 0.059 inch [in.]) of snow (expressed as snow water equivalent) is assumed to melt per day for every degree Celsius that the daily maximum air temperature is above the freezing point of water.

The SWB model uses soil and land-cover information to calculate a maximum soil-water capacity for each grid cell. The maximum soil-water capacity is roughly equivalent to field capacity, which is the soil water held after excess gravitational water has drained away (Veihmeyer and Hendrickson, 1931). The maximum soil-water capacity is calculated as follows:

$$
\begin{gathered}
\text { maximum soil-water capacity }= \\
\text { available soil-water capacity } \times \text { root-zone depth }
\end{gathered}
$$

where available soil-water capacity is the amount of water available for withdrawal by plants in inches of water per foot; root-zone depth has units of feet; and the final maximum soilwater capacity for each grid cell has units of inches, which is the maximum amount of soil-water storage that can take place in a grid cell.

The SWB model output is only limited by the resolution of the climatological data and available land-cover and soil-cover data layers. The model is capable of generating output at daily, monthly, or annual intervals for any of the 
subcomponents, including (1) gross precipitation, (2) temperature (minimum, maximum, mean), (3) interception, (4) surface runoff, and (5) ET (actual, reference).

\section{Model Limitations and Assumptions}

A full understanding of model limitations and assumptions is necessary to better evaluate the performance of any hydrologic model. The SWB model was originally developed to allow for recharge calculations based on readily available data and standardized parameters (Dripps, 2003). With a similar purpose, the Minnesota SWB model described in this report is intended to serve as a resource for watershed planners and groundwater modelers to obtain potential recharge estimates for an area of interest as well as the possible ranges for potential recharge estimates over time. For this purpose, the 15 -year mean annual potential recharge estimate (that is, the mean for the 15-year period 1996-2010) is the most reliable estimate, and the annual mean potential recharge estimates (that is, the means for individual years from 1996 through 2010) indicate the possible range over time.

For the SWB conceptual model used in this study, the base-flow component from the hydrograph separation technique is assumed to be correct, even though this base-flow estimate is a simulated result. For these comparisons all of the SWB potential recharge is assumed to become base flow to the respective gaged watershed. All groundwater exchange between the surficial aquifer and deep aquifers is assumed to be at steady state. Finally, it is assumed that the watershed boundaries of the gaged surface-water bodies coincide with the aquifer watersheds (that is, the areas contributing recharge to the aquifer), even though it is well understood these boundaries do not always coincide (Kanivetsky, 1979). Although these assumptions likely fail in some cases, this technique for validating recharge estimates has been used in many other recharge estimates (for example, Delin and others, 2007; Hart and others, 2008; Healy and Scanlon, 2010) and is an adequate approximation for the purposes of this modeling effort.

The SWB model is a difference model, so any errors in the various hydrologic components (for example, precipitation, snowmelt, outflow, and ET) will be superimposed on the potential recharge error. Errors from the original sources, such as precipitation or temperature (relating to snowmelt and ET), are difficult to quantify; thus, assigning reasonable uncertainty to the potential recharge estimate is challenging. Furthermore, current modeling capabilities are imprecise because recharge rates cannot be directly measured and instead multiple indirect methods need to be used to estimate recharge, all of which have associated errors (Healy and Scanlon, 2010). It is assumed that these errors are small and that these errors will not be as important once scaled up to generate annual potential recharge estimates.

In regards to the potential recharge estimates, it is assumed that the potential recharge eventually becomes actual recharge. Because the path or distance to the water table is not known, the SWB model only represents water leaving the root zone, so it does not take into account lateral movement of water that discharges to nearby surface water bodies before reaching the water table. Most of the major water-table aquifers in Minnesota are unconfined and reasonably close to land surface (for example, outwash, alluvium, and sandy lake deposits). Therefore, the issues related to actual recharge are probably not as important (Kanivetsky, 1979) as for aquifers in other parts of the country, such as the western United States, where depths to the water table can be hundreds of feet.

Lag time also is not accounted for in the SWB model. Recharge in the model is assumed to be instantaneous within the daily time step, whereas actual recharge can take months or even years. Even if the recharge reaches the water table in days to weeks, it can take a much longer period of time for the same recharge water to become base flow in the nearest stream. Because of the lag-time issue, the 15-year mean annual potential recharge estimate (that is, the mean for the 15-year period 1996-2010) is more reliable than the annual potential recharge estimates (that is, the means for individual years from 1996 through 2010), which should be used only as a guide for the range of potential recharge values.

Theoretical limitations to the SWB model relate to the aggregation of meteorological data to daily time steps. Precipitation is aggregated to the daily time step to limit the model run time, and the daily time step generally is the smallest time step available in large meteorological datasets. However, it is known that for an equal amount of precipitation, surface runoff will differ between a 30-minute storm event and a steady rainfall event lasting several hours; in this case, the SWB model cannot distinguish between the two events based on the daily time step. The accuracy of snowmelt timing also will suffer due to the same limitation, because snowmelt is triggered by air temperatures and snow will not always melt at the same rate. With the exception of groundwater-flow models for small areas, daily time steps are considered reasonable and are recommended for water-budget tabulations (Healy and Scanlon, 2010).

\section{Model Description and Inputs}

The SWB model consists of a 1-km grid spacing of 572 rows and 656 columns. The model boundaries are limited to the Minnesota State boundaries, resulting in an irregularly shaped area of approximately 219,000 cells.

This soil-water-balance application using the SWB model consists of the following gridded datasets to calculate recharge on a cell-by-cell basis, as detailed in Westenbroek and others (2010) and illustrated in figure 1: (1) meteorological data (daily precipitation in inches, daily maximum air temperature, daily minimum air temperature), (2) land-cover class, (3) hydrologic soil group, and (4) available soil-water capacity. 


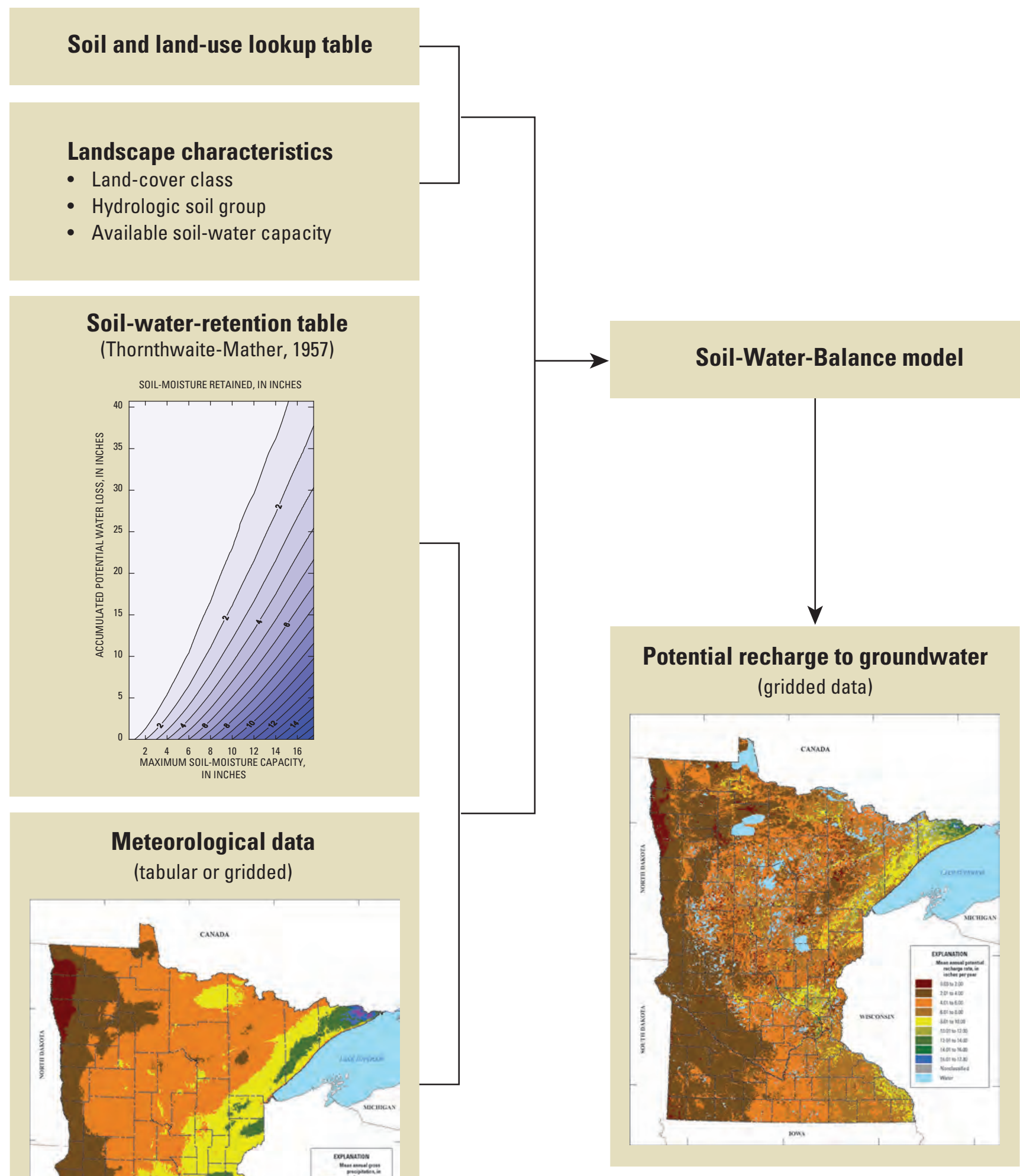

Figure 1. The interaction between the Soil-Water-Balance (SWB) model code and input data (modified from Westenbroek and others, 2010). 
An optional grid for surface-water flow direction was not included as part of the Minnesota SWB application. This grid routes overland flow between cells, which is not pertinent at a $1-\mathrm{km}$ resolution. The lookup tables for (1) soil and land cover and (2) soil-water retention lookup tables are necessary for the SWB code to run. Details of these two lookup tables are given in the "Lookup Tables and Control File" section.

\section{Meteorological Data (Precipitation, Temperature, and Snowmelt)}

All of the potential recharge estimates presented in this report were based on climatological data from the Daymet database (Thornton and others, 2012). This dataset is produced by interpolating available ground observation data with an inverse-distance weighting technique (Thornton and others, 2012). The Daymet data provided daily continuous surfaces of key climatological data, including precipitation and daily minimum/maximum air temperature, which have been broadly applied in hydrological and terrestrial vegetation growth models (Thornton and others, 1997). The Daymet data in Minnesota are based on source data from the Cooperative Summary of the Day network of weather stations, archived and distributed from the National Oceanic and Atmospheric Administration (NOAA) National Climatic Data Center (NCDC).

Mean annual gross precipitation (in inches per year) for 1996-2010 at a 1-km resolution is shown in figure 2. Generally, precipitation is lowest in the northwest and can be as much as 41 inches per year (in/yr) in the northeastern and southeastern parts of the State. The rates in northwest Minnesota are about $21 \mathrm{in} / \mathrm{yr}$, or about one-half of the highest precipitation rates.

\section{Land Cover}

Land-cover data for 1994-2003 were obtained from the 2001 National Land Cover Database (NLCD) (Homer and others, 2007), available from the Multi-Resolution Land Characteristics Consortium. Land cover data for 2004-10 were obtained from the 2006 NLCD classification (Fry and others, 2011). For the NLCD-2001 and NLCD-2006 datasets the land-cover classification consists of 16 classes at a 30 -meter (98-foot) spatial resolution. Fifteen of the 16 landcover classes are found in Minnesota (table 1). However, three classes account for 67 percent of the land cover in NLCD2006 (fig. 3): deciduous forest (15.5 percent), cultivated crops (39.0 percent), and woody wetlands ( 12.7 percent). For comparison, land-cover distributions from NLCD-2001 also are shown in table 1 with only minor differences in all of the 15 classes. For compatible usage with the SWB model, NLCD grids $(2001,2006)$ were resampled to a 1-km grid size using a majority resampling technique available in Esri ArcMap 10.1 (Esri, 2012) and processed into an American Standard Code for Information Interchange (ASCII) data grid.

\section{Hydrologic Soil Groups}

The USDA NRCS has classified more than 14,000 series of soils within the United States into one of four major hydrologic soils groups, which are assigned a letter designation (A-D) based on infiltration capacity. This classification describes soils with similar physical and runoff characteristics, focused specifically on the infiltration capacity of the soil. Soils in group A have a high infiltration capacity, and, consequently a low overland flow potential (Cronshey and others, 1986). In contrast, soils in group $D$ have a very low infiltration capacity, and, consequently a high overland flow potential. As defined by Westenbroek and others (2010), soil group A soils have infiltration rates greater than $(>) 0.30$ inch per hour (in/h), and soil group D soils have infiltration rates less than $(<) 0.05 \mathrm{in} / \mathrm{h}$. Soils in groups B and C have intermediate infiltration capacities from group A and D.

Hydrologic soil group data used in the SWB model were obtained from two separate soil geographic databases, distributed by and available for download from the USDA NRCS (Natural Resources Conservation Service, 2014): (1) the Soil Survey Geographic (SSURGO) database and (2) the State Soil Geographic (STATSGO) database. Both databases are available as georeferenced digital map data and as a relational database. The SSURGO database provides more detailed information than the STATSGO database, so the SSURGO database was used wherever data were available and STATSGO was used to fill in the missing areas. Presently (2014), the SSURGO database has been completed for most of Minnesota except for parts of northeast Minnesota (missing all or part of Cook, Lake, St. Louis, and Pine Counties) and Crow Wing County in north-central Minnesota.

In order to prepare the hydrologic soils group grid, the SSURGO georeferenced digital maps (available at the county scale) were merged with the STATSGO georeferenced digital map that covered the parts of the State not covered by the SSURGO database. This merged digital map was converted to a 1-km grid using the Esri ArcMap 10.1 polygon to raster tool (Esri, 2012), using the maximum combined area option for the cell assignment type (fig. 4). In some cases, the assigned soil group is listed as $\mathrm{A} / \mathrm{D}, \mathrm{B} / \mathrm{D}$, or $\mathrm{C} / \mathrm{D}$ in the databases; the first letter is for the drained condition and the second letter is for the natural condition (Natural Resources Conservation Service, 2005). In these cases, the soil group was truncated to the soil group $\mathrm{A}$ (for $\mathrm{A} / \mathrm{D}$ ), soil group $\mathrm{B}$ (for $\mathrm{B} / \mathrm{D}$ ), or soil group $\mathrm{C}$ (for $\mathrm{C} / \mathrm{D}$ ), given that these soils were generally classified in parts of the State with extensive artificial drainage and in most cases would fall into the drained condition. Next, the hydrologic soil groups (A through D) were converted to a numerical code (1 through 4), and exported to an ASCII file.

A special class was created for this SWB application, listed with a numerical code 5 and shown in figure 4 as group "organic," which generally denotes peat deposits. This unique class was created because of its ability to hold more water than the same volume of a mineral soil (that is, non-organic) 


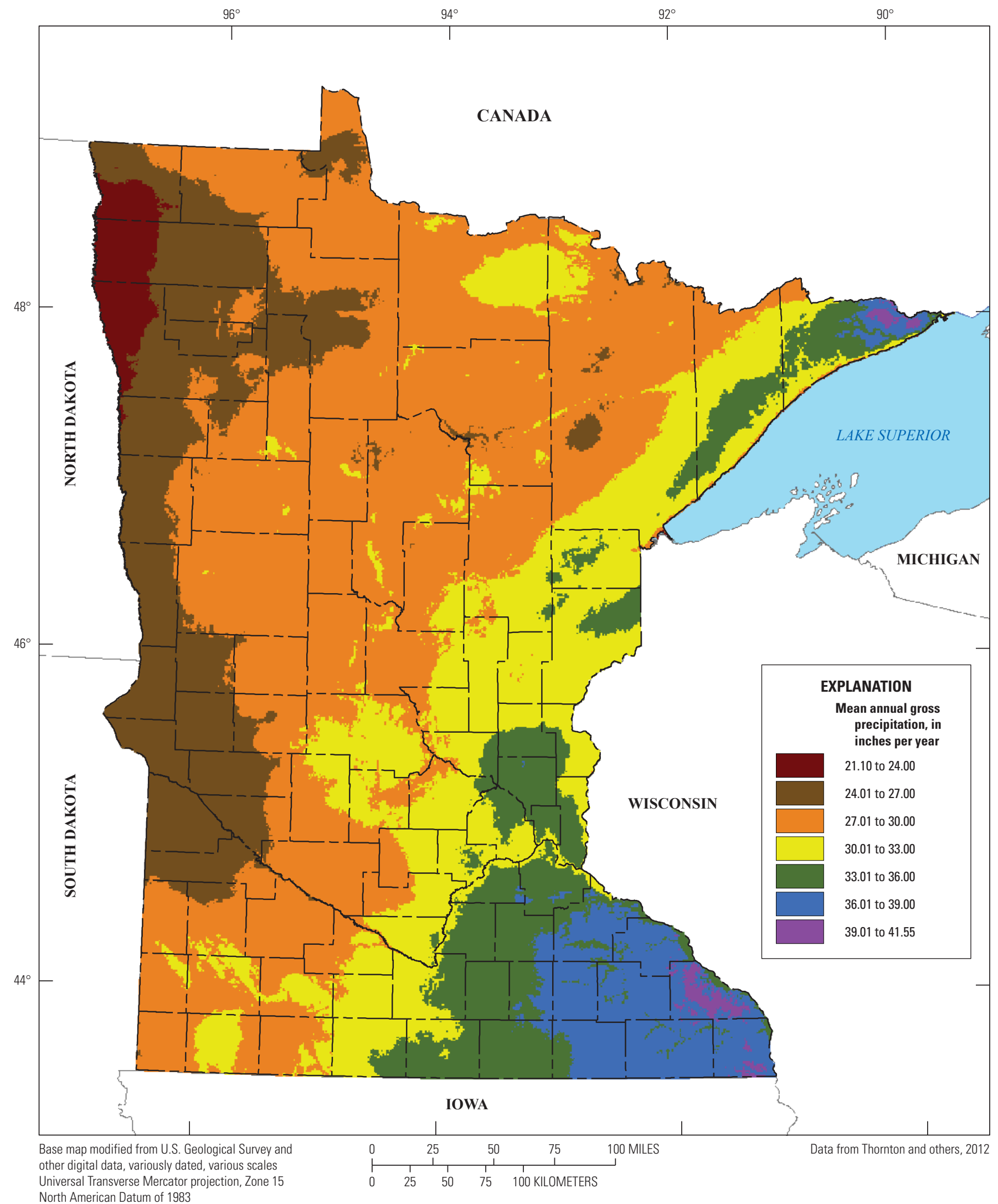

Figure 2. Mean annual gross precipitation in Minnesota at a 1-kilometer resolution, 1996-2010. (Mean gross precipitation rates were reconstructed from gridded datasets from the Soil-Water Balance model output, based on the Daymet climatological dataset [Thornton and others, 2012].) 
Table 1. Distribution of land cover in Minnesota based on the 2001 National Land Cover Database (Homer and others, 2007) and the 2006 National Land Cover Database (Fry and others, 2011).

\begin{tabular}{llcc}
\hline \multirow{2}{*}{ Land-cover class } & \multicolumn{1}{c}{ Description } & \multicolumn{2}{c}{ Land-cover distribution, in percent } \\
\cline { 3 - 4 } & & National Land Cover Dataset, 2001 & National Land Cover Dataset, 2006 \\
\hline 11 & Open water & 6.1 & 6.2 \\
21 & Developed, open space & 2.1 & 2.2 \\
22 & Developed, low intensity & 1.0 & 1.0 \\
23 & Developed, medium intensity & 0.3 & 0.4 \\
24 & Developed, high intensity & 0.1 & 0.2 \\
31 & Barren land (rock/sand/clay) & 0.1 & 0.1 \\
41 & Deciduous forest & 15.5 & 15.4 \\
42 & Evergreen forest & 3.0 & 2.9 \\
43 & Mixed forest & 2.6 & 2.6 \\
52 & Shrubland & 1.5 & 1.5 \\
71 & Grasslands & 2.0 & 2.0 \\
81 & Pasture/hay & 8.2 & 8.2 \\
82 & Cultivated crops & 39.0 & 38.9 \\
90 & Woody wetlands & 12.7 & 12.7 \\
95 & Herbaceous wetlands & 5.6 & 5.7 \\
\hline
\end{tabular}

(Natural Resources Conservation Service, 2008) that potentially would be underpredicted by the SSURGO available soil-water capacity. This special class was derived from the representative organic matter column within the horizon table, defined as the weight percentage of decomposed plant and animal residue in the $<2$-mm $(<0.079$-in. $)$ soil material fraction. Based on a definition of organic soils from Donahue and others (1983), which classified soils with greater than 20 percent organic matter and between 0 and 50 percent clay as an organic soil, soils in this threshold were aggregated with the map unit key to the statewide digital map.

Two of the five hydrologic soil group classes account for 72.1 percent of the hydrologic soil groups (table 2): soil group B (41.3 percent) and soil group C (30.8 percent). Soil group $\mathrm{B}$ is the dominant hydrologic soil group across southern and western Minnesota, with soil group $\mathrm{C}$ as a secondary hydrologic soil group in the same regions in addition to northeastern Minnesota (fig. 4). The special organic group is found primarily in northern Minnesota, in conjunction with the expansive woody and emergent herbaceous wetlands located in that part of the State.

\section{Available Soil-Water Capacity}

The SWB model uses soil information, together with land-cover information, to calculate the maximum soilwater capacity and the available soil-water capacity. Soilwater capacity data were obtained similar to the hydrologic soil group data, whereby the SSURGO database was used wherever data were available and the STATSGO database was used to fill in the missing areas. Both the available soil-water capacity and root-zone depth were extracted from the horizon table (in either the SSURGO or STATSGO database) and aggregated with the map unit key to the statewide digital map. For the available soil-water capacity, the weighted mean of the available soil-water capacity was calculated throughout the soil depth. Similar to the hydrologic soil group grid, the digital map for available soil-water capacity was converted to a $1-\mathrm{km}$ grid using the Esri ArcMap 10.1 polygon to raster tool (Esri, 2012), using the maximum combined area option for the cell assignment type (fig. 5).

\section{Lookup Tables and Control File}

The SWB model uses two lookup tables to assign model cell properties related to soils and land cover: (1) the soil and land-cover lookup table and (2) the extended ThornthwaiteMather soil-water retention table (Thornthwaite and Mather, 1957). The soil and land-cover lookup table cross-references the 15 land-cover classes in Minnesota to the 5 soil classes (4 hydrologic soil group classes plus the special organic soil class) to assign the curve number (Cronshey and others, 1986) (dimensionless number), the maximum recharge rate (inches per day), and the root-zone depth (feet). Additional information includes the interception storage values (inches), both for the growing season and the dormant season. Growing season is triggered by annual GDD exceeding 90 degrees-Fahrenheitdays when the model run is currently in the dormant season, and the dormant season is triggered by the minimum daily air temperature going below 28 degrees Fahrenheit (-2.2 degrees 


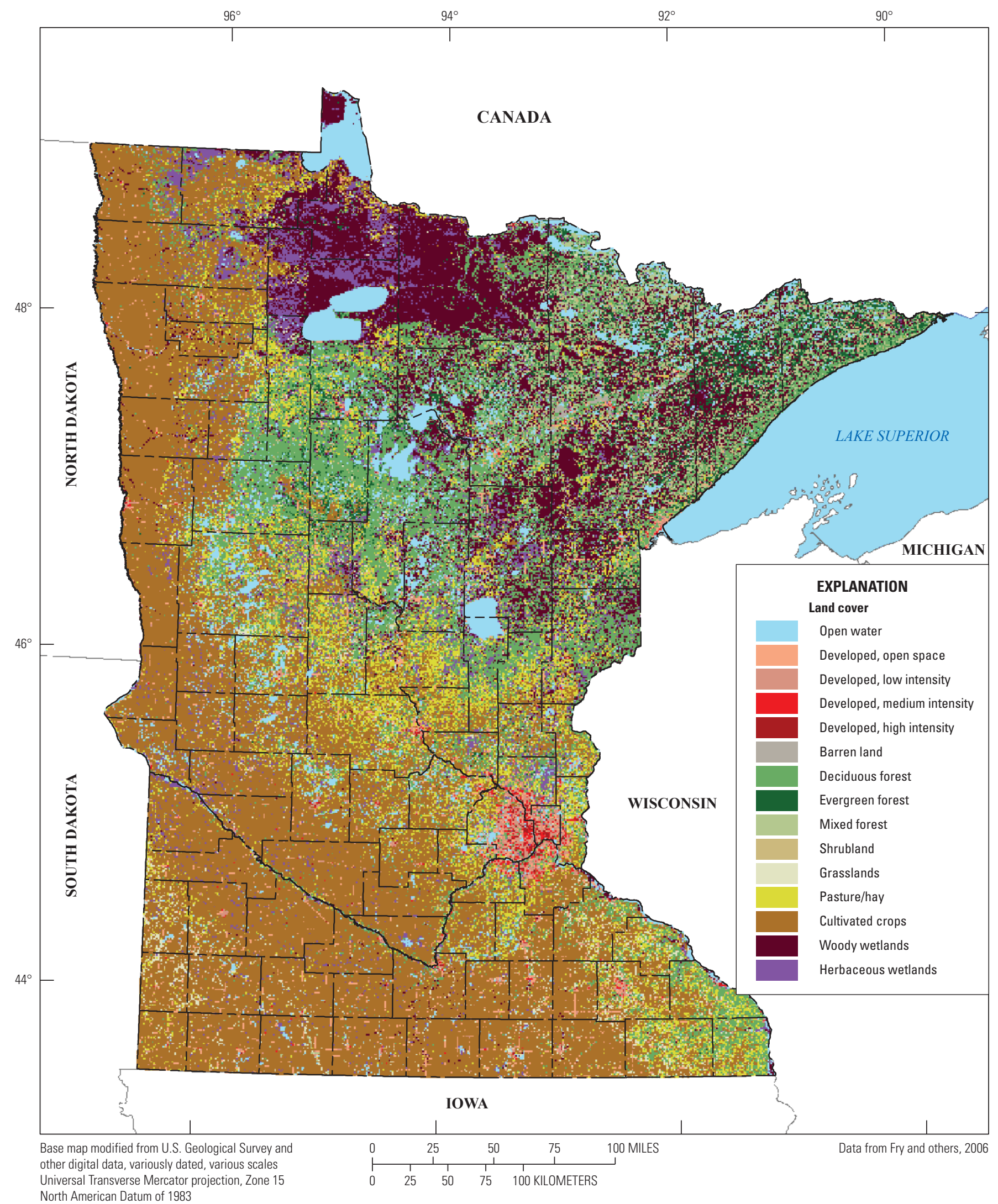

Figure 3. Land cover in Minnesota at a 1-kilometer resolution, from the 2006 National Land Cover Database (Fry and others, 2011). 


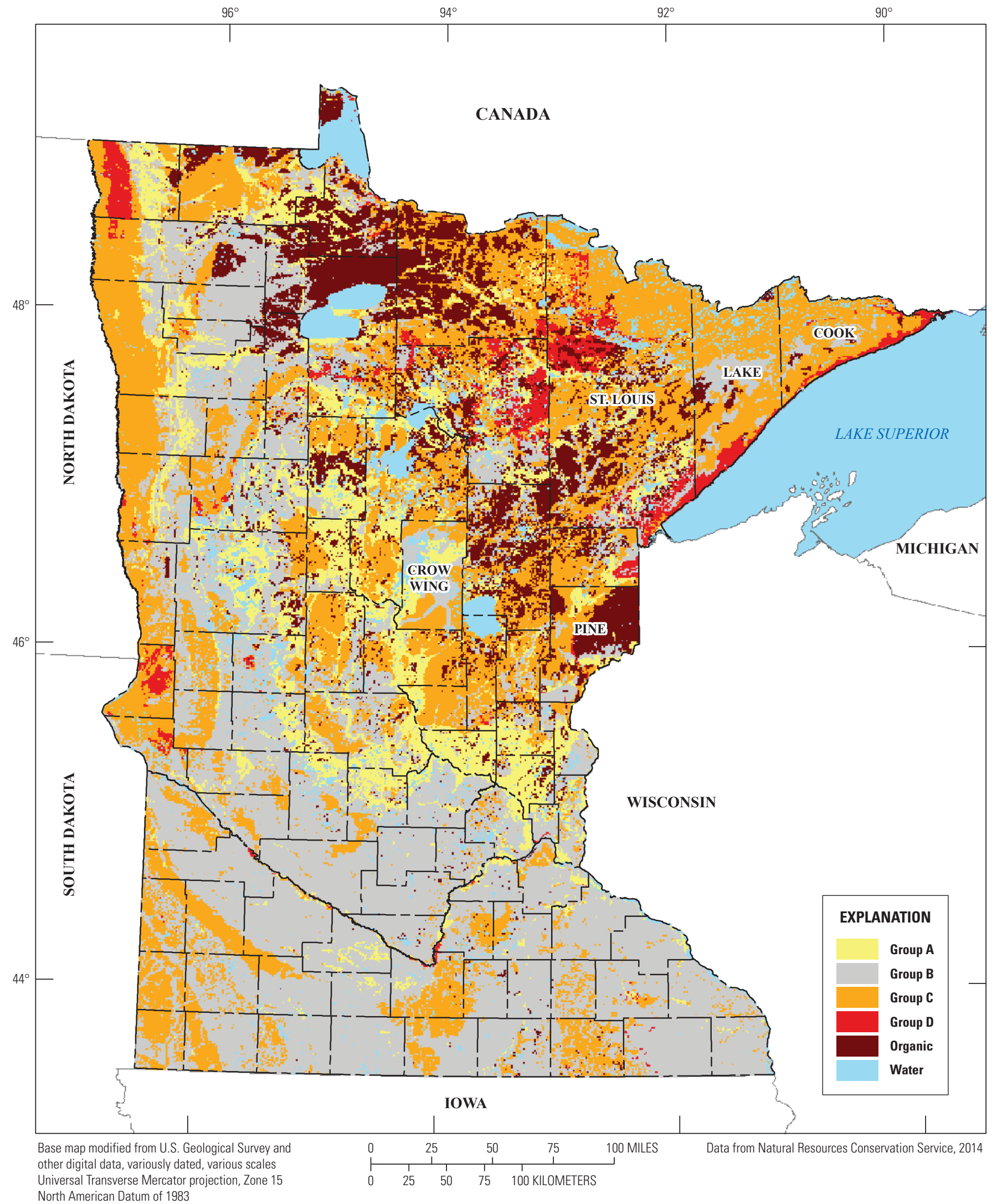

Figure 4. Hydrologic soil groups in Minnesota at a 1-kilometer resolution based on the merged Soil Survey Geographic (SSURGO) and the State Soil Geographic (STATSGO) databases (Natural Resources Conservation Service, 2014). 
Table 2. Distribution of soils in Minnesota based on the Soil Survey Geographic (SSURGO) and the State Soil Geographic (STATSGO) databases (Natural Resources Conservation Service, 2014).

[Details on the designation of the organic soil group are provided in "Hydrologic Soil Groups" section.]

\begin{tabular}{cc}
\hline Hydrologic soil group & Percentage of total Minnesota area \\
\hline A & 13.0 \\
B & 41.3 \\
C & 30.8 \\
D & 3.0 \\
Organic & 11.9 \\
\hline
\end{tabular}

Celsius) when the model run is currently in the growing season. The interception storage values only have a dependence on the NLCD land-cover class and do not have a dependence on the hydrologic soil group. The extended ThornthwaiteMather soil-water retention table describes the ability of different soils to hold water (Thornthwaite and Mather, 1957). This table assists in the calculation of soil moisture adjustments during periods of unsatisfied potential ET.

The lookup table for the SWB model is presented in table 3. The primary calibration for the SWB potential recharge model mainly included adjustments to the soil and land-cover lookup table. Details on calibrating the final recharge model are included in the "Model Calibration" section. No adjustments to the extended Thornthwaite-Mather soil-water retention table were made.

The SWB control file handles all of the user-defined options on how each SWB simulation is run, such as the growing season length, model domain grid definition, the routing method, location of input files, and control over the SWB output. The control file for the SWB model is in appendix 1.

\section{Model Calibration}

Previous SWB model usage included alterations mainly within the soil and land-cover lookup table to attain a reasonable recharge grid (Hart and others, 2009; Hart and Schoephoester, 2011; Masterson and others, 2013; Stanton and others, 2011; Westenbroek and others, 2010). In some cases, comparisons against other simulated results were completed (Hart and others, 2008; Hart and Schoephoester, 2014; Metropolitan Council, 2013). The SWB model for estimating potential recharge in Minnesota described in this report advances SWB model usage beyond previous publications by reporting how well the simulated results fit against the base-flow component derived from three separate hydrograph separation techniques during model calibration. This added complexity provides an independent measure of model performance and the potential uncertainty associated with the final reported potential recharge grid.

The first phase of the SWB model calibration was completed using the parameter estimation code PEST (Doherty, 2010), comparing the potential recharge estimates to base-flow estimates from the hydrograph separation program HYSEP using the local-minimum method (Sloto and Crouse, 1996) for 16 watersheds (table 4). Additional details of the first phase of model calibration using PEST are included in the "Parameter Estimation" subsection. After this initial parameter estimation effort, the potential recharge estimates were manually calibrated with the annual base-flow estimates for 35 watersheds (fig. 6) computed by 3 different hydrograph separation programs. Additional details of the manual calibration are included in the "Hydrograph Separation Comparisons" subsection.

\section{Parameter Estimation}

The first phase of model calibration included adjustments to the SWB model lookup table values of runoff curve number, maximum recharge rate (inches per day), and root-zone depth (feet) using the parameter estimation code PEST (Doherty, 2010). The PEST code was used to improve the match between the estimated potential recharge simulated by using the SWB model and the base-flow component of the hydrograph separation program HYSEP using the local-minimum method. Previously published SWB recharge models (Metropolitan Council, 2013; Westenbroek and others, 2010; Stanton and others, 2011; Masterson and others, 2013) were referred to for starting values for the lookup table. Additionally, table 2.2a-d from Cronshey and others (1986) was referred to throughout the calibration process for guidance on curve numbers; this table is a compilation of runoff curve numbers for different land-cover types, although not directly transferable to the NLCD classification.

The time-series process program TSPROC (Westenbroek and others, 2012) was used by the PEST code as a post-processor to generate the time series for comparison. The TSPROC program and PEST code were part of a composite model that contained multiple processing steps. The TSPROC program imported the streamflow data for a subset of the 35 USGS streamgages (U.S. Geological Survey, 2015), screened out periods with no streamflow data, separated base flow from total flow by using the HYSEP localminimum technique, and converted the base flow to acre-feet per year. The subset of streamgages included only 16 of the 35 streamgages selected as part of the manual calibration process that is described in detail in the following subsection "Hydrograph Separation Comparisons," and is identified in table 4. For the first model run, the TSPROC program created the PEST control and instruction files. Also as part of the composite model, the PAR2PAR preprocessor (part of the PEST suite of programs; Doherty, 2010) enforced relations between particular parameters to lower the overall total 


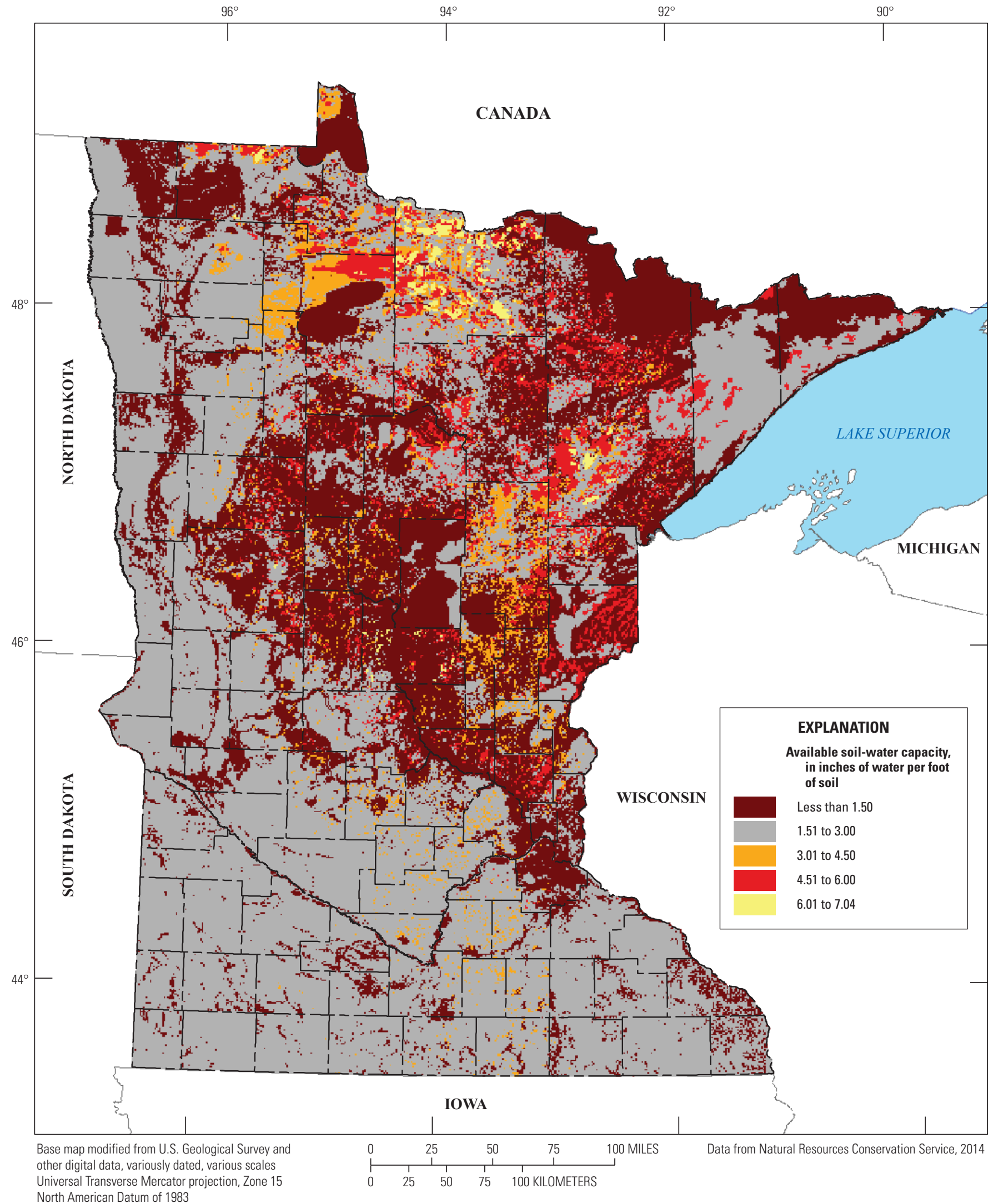

Figure 5. Available soil-water capacity in Minnesota at a 1-kilometer resolution based on the Geographic (SSURGO) and the State Soil Geographic (STATSG0) databases (Natural Resources Conservation Service Soil Survey, 2014). 
Table 3. Lookup table for the Soil-Water-Balance (SWB) model, corresponding land cover to runoff curve number (by hydrologic soil group), maximum recharge rate (by hydrologic soil group), interception storage (growing season/dormant season), and root-zone depth (by hydrologic soil group).

[NA, not applicable; \%, percent]

\begin{tabular}{|c|c|c|c|c|c|c|c|c|c|c|c|c|c|c|c|c|c|c|c|}
\hline \multirow{2}{*}{ 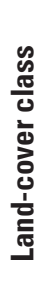 } & \multirow{2}{*}{$\begin{array}{l}\text { 을 } \\
\text { 를 } \\
\text { 口̊ }\end{array}$} & \multirow{2}{*}{ 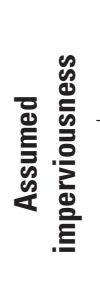 } & \multicolumn{5}{|c|}{ Runoff curve number } & \multicolumn{5}{|c|}{$\begin{array}{l}\text { Maximum recharge rate } \\
\text { (inches per day) }\end{array}$} & \multicolumn{2}{|c|}{$\begin{array}{c}\text { Interception } \\
\text { storage } \\
\text { (inches) }\end{array}$} & \multicolumn{5}{|c|}{ Root-zone depth (feet) } \\
\hline & & & 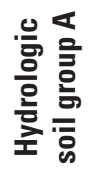 & 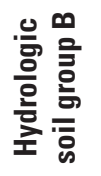 & 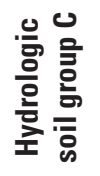 & 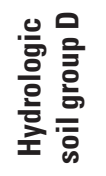 & 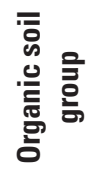 & 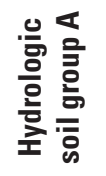 & 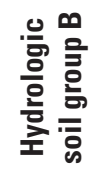 & 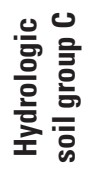 & 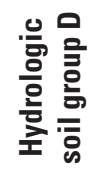 & 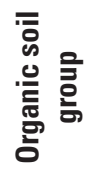 & 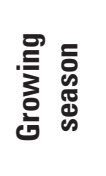 & 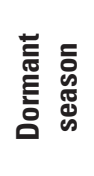 & 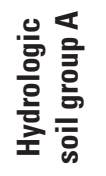 & 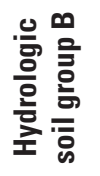 & 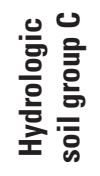 & 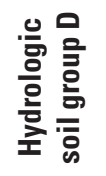 & 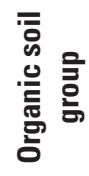 \\
\hline 11 & Open water & NA & 100 & 100 & 100 & 100 & 100 & 4.50 & 2.25 & 1.50 & 0.75 & 1.88 & 0.00 & 0.00 & 0.00 & 0.00 & 0.00 & 0.00 & 0.00 \\
\hline 21 & $\begin{array}{l}\text { Developed, } \\
\text { open space }\end{array}$ & NA & 54 & 70 & 83 & 88 & 76 & 2.50 & 1.50 & 0.83 & 0.42 & 1.04 & 0.03 & 0.00 & 2.66 & 3.32 & 2.12 & 1.33 & 2.72 \\
\hline 22 & $\begin{array}{l}\text { Developed, } \\
\text { low intensity }\end{array}$ & $30 \%$ & 70 & 80 & 87 & 92 & 84 & 2.50 & 1.50 & 0.83 & 0.42 & 1.04 & 0.04 & 0.00 & 3.08 & 3.83 & 2.45 & 1.53 & 3.14 \\
\hline 23 & $\begin{array}{l}\text { Developed, me- } \\
\text { dium intensity }\end{array}$ & $60 \%$ & 82 & 90 & 95 & 97 & 93 & 2.50 & 1.50 & 0.83 & 0.42 & 1.04 & 0.04 & 0.00 & 3.08 & 3.83 & 2.45 & 1.53 & 3.14 \\
\hline 24 & $\begin{array}{l}\text { Developed, } \\
\text { high intensity }\end{array}$ & $90 \%$ & 89 & 92 & 94 & 97 & 93 & 2.50 & 1.50 & 0.83 & 0.42 & 1.04 & 0.04 & 0.00 & 3.08 & 3.83 & 2.45 & 1.53 & 3.14 \\
\hline 31 & $\begin{array}{c}\text { Barren land } \\
\text { (rock/sand/clay) }\end{array}$ & NA & 90 & 93 & 95 & 96 & 94 & 6.00 & 3.50 & 2.75 & 2.00 & 3.13 & 0.06 & 0.00 & 1.00 & 1.00 & 1.00 & 1.00 & 1.00 \\
\hline 41 & Deciduous forest & NA & 30 & 55 & 70 & 77 & 63 & 6.00 & 3.50 & 2.75 & 2.00 & 3.13 & 0.02 & 0.00 & 2.70 & 2.31 & 1.85 & 1.62 & 2.08 \\
\hline 42 & Evergreen forest & NA & 36 & 60 & 73 & 79 & 67 & 6.00 & 3.50 & 2.75 & 2.00 & 3.13 & 0.02 & 0.02 & 3.16 & 2.65 & 2.12 & 1.85 & 2.39 \\
\hline 43 & Mixed forest & NA & 33 & 58 & 72 & 78 & 65 & 6.00 & 3.50 & 2.75 & 2.00 & 3.13 & 0.02 & 0.02 & 2.93 & 2.48 & 1.99 & 1.74 & 2.24 \\
\hline 52 & Shrubland & NA & 39 & 61 & 74 & 80 & 68 & 6.00 & 3.50 & 2.75 & 2.00 & 3.13 & 0.04 & 0.02 & 2.45 & 3.06 & 2.45 & 1.63 & 2.75 \\
\hline 71 & Grasslands & NA & 39 & 61 & 74 & 80 & 68 & 6.00 & 3.50 & 2.75 & 2.00 & 3.13 & 0.04 & 0.02 & 2.24 & 2.80 & 2.24 & 1.49 & 2.51 \\
\hline 81 & Pasture/hay & NA & 49 & 69 & 79 & 84 & 74 & 6.00 & 3.50 & 2.75 & 2.00 & 3.13 & 0.04 & 0.02 & 2.56 & 3.20 & 2.56 & 1.70 & 2.87 \\
\hline 82 & Cultivated crops & NA & 67 & 78 & 85 & 89 & 82 & 6.00 & 3.50 & 2.75 & 2.00 & 3.13 & 0.04 & 0.00 & 2.12 & 1.93 & 1.89 & 1.35 & 1.91 \\
\hline 90 & Woody wetlands & NA & 60 & 60 & 60 & 60 & 60 & 2.00 & 1.00 & 0.67 & 0.33 & 0.83 & 0.02 & 0.00 & 1.30 & 1.44 & 1.30 & 1.14 & 1.37 \\
\hline 95 & $\begin{array}{l}\text { Herbaceous } \\
\text { wetlands }\end{array}$ & NA & 60 & 60 & 60 & 60 & 60 & 2.00 & 1.00 & 0.67 & 0.33 & 0.83 & 0.02 & 0.00 & 1.58 & 1.76 & 1.58 & 1.40 & 1.67 \\
\hline
\end{tabular}


Table 4. Mean annual base-flow estimates from 1996-2010 using 3 hydrograph separation techniques for the watersheds of 35 streamgages used in model calibration in comparison to the estimated potential recharge rates for the same period from the Soil-Water-Balance (SWB) model.

[USGS, U.S. Geological Survey; mi², square miles; in/yr, inches per year; SWB, Soil-Water-Balance; Minn., Minnesota; NA, not applicable]

\begin{tabular}{|c|c|c|c|c|c|c|c|c|c|c|}
\hline \multirow[b]{2}{*}{$\begin{array}{l}\text { Map number } \\
\text { for watershed } \\
\text { associated with } \\
\text { streamgage } \\
\text { (fig. 6) }\end{array}$} & \multirow[b]{2}{*}{ USGS streamgage name or statistic } & \multirow[b]{2}{*}{$\begin{array}{c}\text { USGS } \\
\text { streamgage } \\
\text { number }\end{array}$} & \multirow[b]{2}{*}{$\begin{array}{c}\text { Drainage } \\
\text { area } \\
\left(\mathrm{mi}^{2}\right)\end{array}$} & \multirow[b]{2}{*}{$\begin{array}{c}\text { PEST }^{a} \\
\text { calibra- } \\
\text { tion }\end{array}$} & \multirow[b]{2}{*}{$\begin{array}{c}\text { Manual } \\
\text { calibration, } \\
\text { period } \\
\text { analyzed }\end{array}$} & \multicolumn{3}{|c|}{ Base-flow estimate (in/yr) } & \multirow{2}{*}{$\begin{array}{c}\text { Potential } \\
\text { recharge rate } \\
\text { from SWB } \\
\text { model } \\
\text { (in/yr) }\end{array}$} & \multirow[b]{2}{*}{$\begin{array}{l}\text { Relative } \\
\text { error }^{\mathrm{d}}\end{array}$} \\
\hline & & & & & & $\begin{array}{l}\text { PART }^{\mathrm{b}} \\
\text { (in/yr) }\end{array}$ & $\begin{array}{l}\text { HYSEP } \\
\text { fixed- } \\
\text { interval } \\
\text { method }^{\mathrm{c}}\end{array}$ & $\begin{array}{l}\text { HYSEP } \\
\text { sliding } \\
\text { methodc }^{\text {Hothed }}\end{array}$ & & \\
\hline 1 & Knife River near Two Harbors, Minn. & 04015330 & 84 & Yes & $1996-2010$ & 7.33 & 7.58 & 7.50 & 8.40 & 0.12 \\
\hline 2 & $\begin{array}{l}\text { Otter Tail River below Orwell Dam near } \\
\text { Fergus Falls, Minn. }\end{array}$ & 05046000 & 1,740 & No & $1996-2010$ & 5.00 & 4.91 & 4.90 & 4.49 & -0.09 \\
\hline 3 & Buffalo River near Dilworth, Minn. & 05062000 & 975 & No & 1996-2010 & 3.47 & 3.27 & 3.33 & 4.05 & 0.20 \\
\hline 4 & Wild River River at Twin Valley, Minn. & 05062500 & 934 & Yes & $1996-2010$ & 4.34 & 4.12 & 4.14 & 4.35 & 0.03 \\
\hline 5 & Sand Hill River at Climax, Minn. & 05069000 & 420 & Yes & $1996-2010$ & 3.11 & 3.08 & 3.03 & 3.58 & 0.17 \\
\hline 6 & Red Lake River near Red Lake, Minn. & 05074500 & 1,950 & No & $2000-2010$ & 2.92 & 3.04 & 3.03 & 3.72 & 0.24 \\
\hline 7 & Thief River near Thief River Falls, Minn. & 05076000 & 985 & No & $\begin{array}{l}1996-1999 \\
2001-05 \\
2008-10\end{array}$ & 4.61 & 4.47 & 4.47 & 3.92 & -0.13 \\
\hline 8 & Clearwater River at Plummer, Minn. & 05078000 & 555 & Yes & $1996-2010$ & 4.03 & 3.73 & 3.77 & 3.62 & -0.06 \\
\hline 9 & Lost River at Oklee, Minn. & 05078230 & 254 & Yes & $1996-2010$ & 3.01 & 2.75 & 2.77 & 3.24 & 0.14 \\
\hline 10 & Middle River at Argyle, Minn. & 05087500 & 255 & Yes & $1996-2010$ & 3.09 & 2.68 & 2.76 & 3.43 & 0.21 \\
\hline 11 & $\begin{array}{l}\text { South Branch Two Rivers at Lake Bronson, } \\
\text { Minn. }\end{array}$ & 05094000 & 422 & No & $1996-2010$ & 3.59 & 3.50 & 3.48 & 3.93 & 0.12 \\
\hline 12 & Kawishiwi River near Winton, Minn. & 05127000 & 1,230 & No & 1996-2010 & 7.16 & 7.41 & 7.41 & 7.68 & 0.05 \\
\hline 13 & Little Fork River at Littlefork, Minn. & 05131500 & 1,680 & Yes & $1996-2010$ & 6.07 & 5.47 & 5.47 & 5.33 & -0.06 \\
\hline 14 & Big Fork River at Big Falls, Minn. & 05132000 & 1,480 & No & $1998-2010$ & 5.44 & 5.03 & 5.01 & 4.68 & -0.09 \\
\hline 15 & Crow Wing River at Nimrod, Minn. & 05244000 & 1,030 & Yes & $1996-2010$ & 6.20 & 5.98 & 5.97 & 5.38 & -0.11 \\
\hline 16 & Long Prairie River at Long Prairie, Minn. & 05245100 & 434 & Yes & $1996-2010$ & 5.23 & 4.99 & 4.99 & 4.22 & -0.17 \\
\hline 17 & Sauk River near St. Cloud, Minn. & 05270500 & 1,030 & No & $1996-2010$ & 4.68 & 4.44 & 4.43 & 4.85 & 0.07 \\
\hline 18 & Elk River near Big Lake, Minn. & 05275000 & 599 & No & $1996-2010$ & 5.68 & 5.44 & 5.43 & 6.22 & 0.13 \\
\hline 19 & Rum River near St. Francis, Minn. & 05286000 & 1,360 & Yes & $1996-2010$ & 5.56 & 5.31 & 5.28 & 6.16 & 0.14 \\
\hline 20 & Elk Creek near Champlin, Minn. & 05287890 & 86 & No & $1996-2010$ & 4.89 & 4.75 & 4.72 & 4.80 & 0.00 \\
\hline 21 & Pomme de Terre River at Appleton, Minn. & 05294000 & 905 & No & $\begin{array}{l}1996-98 \\
2004-10\end{array}$ & 3.36 & 3.33 & 3.31 & 3.93 & 0.18 \\
\hline 22 & Chippewa River near Milan, Minn. & 05304500 & 1,880 & Yes & $1996-2010$ & 3.54 & 3.35 & 3.32 & 3.62 & 0.06 \\
\hline 23 & $\begin{array}{l}\text { Yellow Medicine River near Granite Falls, } \\
\text { Minn. }\end{array}$ & 05313500 & 666 & Yes & $1996-2010$ & 2.97 & 2.89 & 2.81 & 3.17 & 0.10 \\
\hline
\end{tabular}


Table 4. Mean annual base-flow estimates from 1996-2010 using 3 hydrograph separation techniques for the watersheds of 35 streamgages used in model calibration in comparison to the estimated potential recharge rates for the same period from the Soil-Water-Balance (SWB) model.—Continued

[USGS, U.S. Geological Survey; mi², square miles; in/yr, inches per year; SWB, Soil-Water-Balance; Minn., Minnesota; NA, not applicable]

\begin{tabular}{|c|c|c|c|c|c|c|c|c|c|c|}
\hline \multirow[b]{2}{*}{$\begin{array}{l}\text { Map number } \\
\text { for watershed } \\
\text { associated with } \\
\text { streamgage } \\
\text { (fig. 6) }\end{array}$} & \multirow[b]{2}{*}{ USGS streamgage name or statistic } & \multirow[b]{2}{*}{$\begin{array}{c}\text { USGS } \\
\text { streamgage } \\
\text { number }\end{array}$} & \multirow[b]{2}{*}{$\begin{array}{c}\text { Drainage } \\
\text { area } \\
\left(\mathrm{mi}^{2}\right)\end{array}$} & \multirow[b]{2}{*}{$\begin{array}{c}\text { PESTa }^{\text {calibra- }} \\
\text { calion }\end{array}$} & \multirow[b]{2}{*}{$\begin{array}{c}\text { Manual } \\
\text { calibration, } \\
\text { period } \\
\text { analyzed }\end{array}$} & \multicolumn{3}{|c|}{ Base-flow estimate (in/yr) } & \multirow[b]{2}{*}{$\begin{array}{l}\text { Potential } \\
\text { recharge rate } \\
\text { from SWB } \\
\text { model } \\
\text { (in/yr) }\end{array}$} & \multirow[b]{2}{*}{$\begin{array}{l}\text { Relative } \\
\text { error }^{\mathrm{d}}\end{array}$} \\
\hline & & & & & & $\begin{array}{l}\text { PART } \\
\text { (in/yr) }\end{array}$ & $\begin{array}{l}\text { HYSEP } \\
\text { fixed- } \\
\text { interval } \\
\text { method }^{c}\end{array}$ & $\begin{array}{l}\text { HYSEP } \\
\text { sliding } \\
\text { method }^{c}\end{array}$ & & \\
\hline 24 & Redwood River near Marshall, Minn. & 05315000 & 259 & Yes & $1996-2010$ & 3.94 & 3.49 & 3.51 & 3.67 & 0.01 \\
\hline 25 & Cottonwood River near New Ulm, Minn. & 05317000 & 1,300 & No & 1996-2010 & 4.02 & 3.52 & 3.60 & 3.68 & -0.01 \\
\hline 26 & $\begin{array}{l}\text { Little Cottonwood River near Courtland, } \\
\text { Minn. }\end{array}$ & 05317200 & 170 & No & $1996-2009$ & 4.40 & 4.35 & 4.38 & 3.58 & -0.18 \\
\hline 27 & Watonwan River near Garden City, Minn. & 05319500 & 851 & No & 1996-2010 & 4.92 & 4.76 & 4.70 & 4.00 & -0.16 \\
\hline 28 & Le Sueur River near Rapidan, Minn. & 05320500 & 1,110 & Yes & 1996-2010 & 6.04 & 5.26 & 5.32 & 4.99 & -0.10 \\
\hline 29 & High Island Creek near Henderson, Minn. & 05327000 & 238 & No & $1996-2010$ & 4.41 & 4.44 & 4.42 & 3.98 & -0.10 \\
\hline 30 & Kettle River below Sandstone, Minn. & 05336700 & 868 & Yes & $1996-2010$ & 7.48 & 6.82 & 6.91 & 6.92 & -0.02 \\
\hline 31 & Snake River near Pine City, Minn. & 05338500 & 974 & Yes & $1996-2010$ & 6.64 & 6.47 & 6.49 & 5.44 & -0.17 \\
\hline 32 & Vermillion River near Empire, Minn. & 05345000 & 129 & No & $1996-2010$ & 7.15 & 6.90 & 6.93 & 7.04 & 0.01 \\
\hline 33 & Cannon River at Welch, Minn. & 05355200 & 1,340 & No & $1996-2010$ & 7.01 & 6.31 & 6.38 & 6.05 & -0.08 \\
\hline 34 & $\begin{array}{l}\text { South Fork Zumbro River at Rochester, } \\
\text { Minn. }\end{array}$ & 05372995 & 303 & No & $1996-2010$ & 7.17 & 6.63 & 6.57 & 6.57 & -0.03 \\
\hline 35 & Cedar River near Austin, Minn. & 05457000 & 399 & No & $1996-2010$ & 7.28 & 6.83 & 6.82 & 6.14 & -0.12 \\
\hline NA & Minimum & NA & 84 & NA & NA & 2.92 & 2.68 & 2.76 & 3.17 & -0.18 \\
\hline NA & Maximum & NA & 1,950 & NA & NA & 7.48 & 7.58 & 7.50 & 8.40 & 0.24 \\
\hline \multicolumn{11}{|l|}{ aDoherty (2010). } \\
\hline \multicolumn{11}{|c|}{ 'Rutledge (1998). } \\
\hline \multicolumn{11}{|c|}{ 'sloto and Crouse (1996). } \\
\hline
\end{tabular}




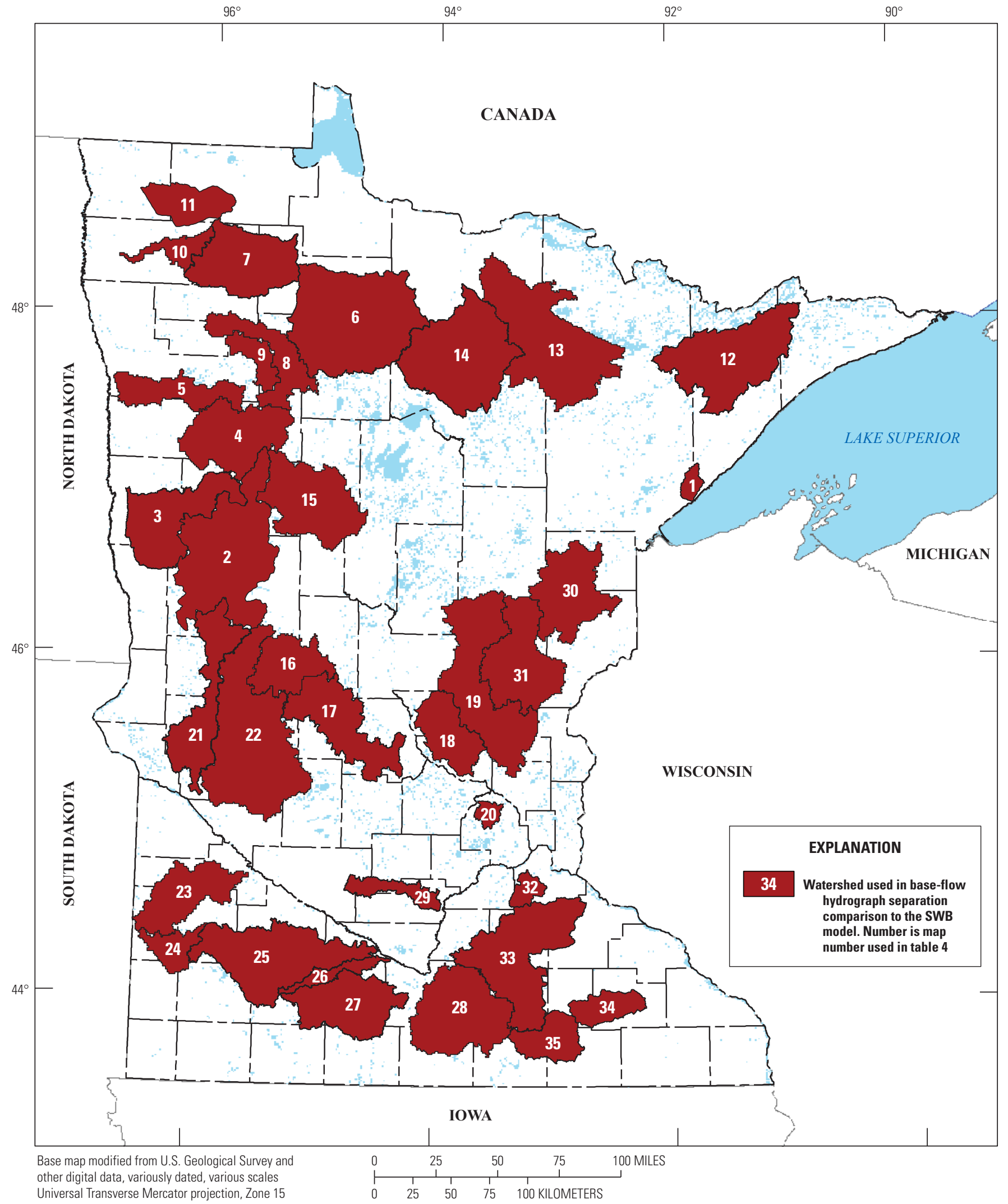

tor projection, Zone 15

Figure 6. Watersheds with continuous streamflow data from 1996-2010 used for calibration of the Soil-Water-Balance (SWB) model. 
of estimated parameters. For example, because runoff curve numbers increase from soil group A to soil group $\mathrm{D}$, a relation calculated the runoff curve number for soil group $\mathrm{C}$ based on the estimated runoff curve number for soil group B. Likewise, similar relations were enforced by relating all other soil groups to soil group B, thereby reducing the number of parameters to be estimated from five to one. Because Minnesota has 15 different land-cover classes, a total of 75 combinations exist between land-cover classes and the 5 soil groups. By enforcing these relations, only 15 parameters needed to be estimated. Likewise, similar relations were enforced for root-zone depth and for particular land-cover types such as the four different types of urban land cover, further reducing the number of parameters to be estimated.

The PEST code was used to carry out parameter estimation by modifying the model parameters incrementally. For an individual iteration, a single model parameter was altered by an automatically adjusted percentage to determine if the new parameter value improved the difference between the simulated and measured (observed) values. An individual iteration consisted of running the SWB model for each of the 16 watersheds separately from 2000 to 2007 . The new parameter value was retained if the overall objective function was reduced; for the SWB model, the objective function was the sum of squared deviations (also known as discrepancies) between the simulated values (the annual SWB potential recharge estimates in acre-feet per year) and the measured values (the base-flow estimated from the HYSEP local-minimum method in acrefeet per year) for all 16 watersheds. As part of the process, the various discrepancies can be weighted in different amounts to favor certain measured (observed) values, such as those with a smaller standard deviation. After completion of the individual SWB model runs for each watershed, the TSPROC program was called to generate the output files for comparison, a new objective function was calculated, and a new model parameter was adjusted. This parameter estimation cycle continued until PEST failed to lower the objective function over four iterations.

Overall, the parameter estimation process did not result in the final calibrated parameter values for the SWB model lookup table. Part of the challenge of the parameter estimation process was correctly assigning the weighting factors for the measured (observed) data. Also, because of the many parameters for estimation and the fact that different combinations of curve numbers and root-zone depths for the same land cover can yield the same results, leading to a non-unique solution, additional simulations using the SWB model were carried out through manual parameter adjustments.

\section{Hydrograph Separation Comparisons}

The second phase of the model calibration consisted of manually calibrating the potential recharge estimates by using the annual base-flow estimates for 35 watersheds. The annual base-flow estimates were generated by using three different hydrograph separation techniques using USGS groundwater software (http://water.usgs.gov/software/lists/groundwater): PART (Rutledge, 1998), HYSEP fixed-interval method (Sloto and Crouse, 1996), and HYSEP sliding method (Sloto and Crouse, 1996). These three different hydrograph separation techniques were chosen to avoid a potential singular bias had only one hydrograph separation technique been used, providing a consensus approach among the three different hydrograph separation techniques for calibrating the model. All 35 watersheds selected (fig. 6) for the manual calibration process have at least 10 years of continuous streamflow data for the calibration period 1996-2010 (table 4) and combined, represent a similar distribution of land cover (table 5) as the State. The calibration watersheds range in size from 84 to $1,950 \mathrm{mi}^{2}$.

The goodness-of-fit between the 15-year mean annual potential recharge estimates from the SWB model and the 15 -year mean annual base-flow estimates from the three different hydrograph separation techniques was considered during model calibration. The five quantities used to evaluate the goodness-of-fit were (1) the absolute mean error (AME), (2) the root mean square error (RMSE), (3) the Nash-Sutcliffe model efficiency coefficient (NSE), (4) the coefficient of determination $\left(R^{2}\right)$, and (5) the relative error. The AME, computed by equation 3 for each of the 35 calibration watersheds, is a measure of the mean difference between the simulated (potential recharge estimate) and measured (hydrograph separation base-flow estimate) values:

$$
A M E=\frac{1}{n} \sum_{i=1}^{n}\left|P_{i}-O_{i}\right|
$$

where $n$ is the number of years of streamflow data at each streamgage, $P_{i}$ is the predicted (simulated) value, and $O_{i}$ is the observed value. For example, an AME of $1.0 \mathrm{in} / \mathrm{yr}$ for the SWB potential recharge estimate means that this predicted value is on average within $1.0 \mathrm{in} / \mathrm{yr}$ of the observed value. In this case, the observed estimate is the base-flow estimate from the hydrograph separation technique.

The RMSE indicates the amount of deviation between the simulated value and the measured value. The RMSE, computed by equation 4 , yields the deviation between the simulated (potential recharge estimate) and measured (hydrograph separation base-flow estimate) values approximately 67 percent of the time:

$$
R M S E=\sqrt{\frac{1}{n} \sum_{i=1}^{n}\left(P_{i}-O_{i}\right)^{2}}
$$

The AME and RMSE were evaluated at two different spatial scales for each of the three hydrograph separation techniques: (1) the State as a single metric, shown as the overall mean of the AME and RMSE values for the 35 gaged watersheds (table 6); and (2) for each of the 35 individual gaged watersheds (table 6). 
Table 5. Distribution of land cover in Minnesota for the 35 selected watersheds and for the State, based on the 2006 National Land Cover Database (Fry and others, 2011).

\begin{tabular}{clccc}
\hline \multirow{2}{*}{ Land-cover class } & \multicolumn{1}{c}{ Description } & \multicolumn{2}{c}{ Land-cover distribution, in percent } & $\begin{array}{c}\text { Percent difference between } \\
\text { selected watersheds } \\
\text { and entire State }\end{array}$ \\
\cline { 3 - 4 } & $\begin{array}{c}\text { 35 Selected watersheds } \\
\text { (table 4) }\end{array}$ & Entire State & 0.6 \\
\hline 11 & Open water & 6.8 & 6.2 & -0.2 \\
21 & Developed, open space & 2.0 & 2.2 & -0.4 \\
22 & Developed, low intensity & 0.6 & 1.0 & -0.2 \\
23 & Developed, medium intensity & 0.2 & 0.4 & -0.1 \\
24 & Developed, high intensity & 0.1 & 0.2 & 0.2 \\
31 & Barren land (rock/sand/clay) & 0.4 & 0.1 & 0.2 \\
41 & Deciduous forest & 15.7 & 15.4 & 0.1 \\
42 & Evergreen forest & 3.0 & 2.9 & -0.6 \\
43 & Mixed forest & 2.0 & 2.6 & -0.4 \\
52 & Shrubland & 1.1 & 1.5 & 0.0 \\
71 & Grasslands & 2.0 & 2.0 & 1.3 \\
81 & Pasture/hay & 9.5 & 8.2 & 0.6 \\
82 & Cultivated crops & 39.5 & 38.9 & -1.3 \\
90 & Woody wetlands & 11.4 & 12.7 & 0.1 \\
\hline 95 & Herbaceous wetlands & 5.7 & 5.7 & \\
\hline
\end{tabular}

The third statistical measure used for comparison, the NSE (Nash and Sutcliffe, 1970), was evaluated between the 15-year mean annual base-flow estimates from all three hydrograph separation techniques (PART, HYSEP fixed-interval method, and HYSEP sliding method) and the 15-year mean annual potential recharge estimates from the SWB model. The NSE is a commonly used estimate of the goodness-of-fit for hydrologic models (Legates and McCabe, 1999). Although commonly used for the evaluation of transient models, the NSE, in this case, can evaluate if the 15-year mean annual potential recharge estimates from the SWB model are better than the 15-year mean annual base-flow estimates for each of the three hydrograph separation techniques. The NSE was computed by equation 5 :

$$
N S E=1-\frac{\frac{1}{n} \sum_{i=1}^{n}\left(O_{i}-P_{i}\right)^{2}}{\frac{1}{n} \sum_{i=1}^{n}\left(O_{i}-\bar{O}\right)^{2}}
$$

where $\bar{O}$ is the mean of the observed data. For the NSE, a value of 1 is considered a perfect match between the model simulations and observations, a value of 0 denotes that the observed mean is as good as a predictor as the model simulations, and negative values for NSE indicate that the observed mean is a better predictor than the model. Although there was not an official threshold of acceptability for the SWB model, an NSE value $>0.80$ was assumed to be a good model fit.

The fourth statistical measure used was the coefficient of determination $\left(R^{2}\right)$. Linear models were constructed comparing the 15-year mean annual base-flow estimate to the 15 -year mean annual potential recharge estimate for each of the 35 watersheds. A linear model was constructed for each of the hydrograph separation base-flow estimates, with the goodnessof-fit evaluated by the coefficient of determination $\left(R^{2}\right)$. The $R^{2}$ value was calculated with equation 6 :

$$
R^{2}=\left\{\frac{\sum_{i=1}^{n}\left(O_{i}-\bar{O}\right)\left(P_{i}-\bar{P}\right)}{\left[\sum_{i=1}^{n}\left(O_{i}-\bar{O}\right)^{2}\right]^{0.5}\left[\sum_{i=1}^{n}\left(P_{i}-\bar{P}\right)^{2}\right]^{0.5}}\right\}^{2}
$$

where $\bar{P}$ is the mean of the predicted data. As with the NSE, an $R^{2}$ value of $>0.80$ for each linear model was assumed to be a good model fit. 
Table 6. Absolute mean error (AME) and root mean square error (RMSE) between the annual mean potential recharge estimate from the Soil-Water-Balance (SWB) model and the annual mean base-flow estimates from the three hydrograph separation techniques for the overall calibration period (1996-2010) for 35 selected watersheds.

[USGS, U.S. Geological Survey; in/yr, inches per year; Minn., Minnesota; NA, not applicable]

\begin{tabular}{|c|c|c|c|c|c|c|c|c|}
\hline \multirow{2}{*}{$\begin{array}{l}\text { Map number } \\
\text { for watershed } \\
\text { associated with } \\
\text { streamgage } \\
\text { (fig. 6) }\end{array}$} & \multirow[b]{2}{*}{ USGS streamgage name or statistic } & \multirow[b]{2}{*}{$\begin{array}{c}\text { USGS } \\
\text { streamgage } \\
\text { number }\end{array}$} & \multicolumn{3}{|c|}{ AME (in/yr) } & \multicolumn{3}{|c|}{ RMSE (in/yr) } \\
\hline & & & $\begin{array}{l}\text { PART'a } \\
\text { (in/yr) }\end{array}$ & $\begin{array}{c}\text { HYSEP } \\
\text { fixed-interval } \\
\text { method }^{\mathrm{b}}\end{array}$ & $\begin{array}{l}\text { HYSEP } \\
\text { sliding } \\
\text { methodb }\end{array}$ & $\begin{array}{l}\text { PART }^{a} \\
\text { (in/yr) }\end{array}$ & $\begin{array}{c}\text { HYSEP } \\
\text { fixed-interval } \\
\text { method }^{b}\end{array}$ & $\begin{array}{l}\text { HYSEP } \\
\text { sliding } \\
\text { method }^{\text {b }}\end{array}$ \\
\hline 1 & Knife River near Two Harbors, Minn. & 04015330 & 1.66 & 1.73 & 1.61 & 2.27 & 2.25 & 2.16 \\
\hline 2 & Otter Tail River below Orwell Dam near Fergus Falls, Minn. & 05046000 & 1.48 & 1.43 & 1.43 & 1.67 & 1.63 & 1.62 \\
\hline 3 & Buffalo River near Dilworth, Minn. & 05062000 & 1.14 & 1.31 & 1.24 & 1.41 & 1.62 & 1.56 \\
\hline 4 & Wild River River at Twin Valley, Minn. & 05062500 & 1.63 & 1.71 & 1.70 & 1.80 & 1.93 & 1.90 \\
\hline 5 & Sand Hill River at Climax, Minn. & 05069000 & 1.18 & 1.32 & 1.31 & 1.47 & 1.52 & 1.55 \\
\hline 6 & Red Lake River near Red Lake, Minn. & 05074500 & 1.65 & 1.68 & 1.67 & 1.98 & 1.99 & 1.98 \\
\hline 7 & Thief River near Thief River Falls, Minn. & 05076000 & 1.63 & 1.47 & 1.49 & 2.05 & 1.95 & 1.97 \\
\hline 8 & Clearwater River at Plummer, Minn. & 05078000 & 1.21 & 1.21 & 1.17 & 1.43 & 1.47 & 1.46 \\
\hline 9 & Lost River at Oklee, Minn. & 05078230 & 1.16 & 1.31 & 1.23 & 1.42 & 1.60 & 1.48 \\
\hline 10 & Middle River at Argyle, Minn. & 05087500 & 1.39 & 1.74 & 1.59 & 1.88 & 2.21 & 2.11 \\
\hline 11 & South Branch Two Rivers at Lake Bronson, Minn. & 05094000 & 1.85 & 1.77 & 1.76 & 2.29 & 2.15 & 2.18 \\
\hline 12 & Kawishiwi River near Winton, Minn. & 05127000 & 1.90 & 1.93 & 1.97 & 2.23 & 2.36 & 2.36 \\
\hline 13 & Little Fork River at Littlefork, Minn. & 05131500 & 1.34 & 1.20 & 1.16 & 1.77 & 1.54 & 1.52 \\
\hline 14 & Big Fork River at Big Falls, Minn. & 05132000 & 1.39 & 1.15 & 1.16 & 1.54 & 1.35 & 1.34 \\
\hline 15 & Crow Wing River at Nimrod, Minn. & 05244000 & 1.64 & 1.54 & 1.55 & 1.91 & 1.80 & 1.81 \\
\hline 16 & Long Prairie River at Long Prairie, Minn. & 05245100 & 1.77 & 1.68 & 1.66 & 2.11 & 1.99 & 1.98 \\
\hline 17 & Sauk River near St. Cloud, Minn. & 05270500 & 1.50 & 1.58 & 1.59 & 1.78 & 1.89 & 1.90 \\
\hline 18 & Elk River near Big Lake, Minn. & 05275000 & 1.96 & 2.10 & 2.08 & 2.29 & 2.43 & 2.41 \\
\hline 19 & Rum River near St. Francis, Minn. & 05286000 & 1.97 & 2.05 & 2.08 & 2.44 & 2.57 & 2.57 \\
\hline 20 & Elk Creek near Champlin, Minn. & 05287890 & 1.76 & 1.88 & 1.83 & 2.11 & 2.16 & 2.13 \\
\hline 21 & Pomme de Terre River at Appleton, Minn. & 05294000 & 1.09 & 1.07 & 1.08 & 1.32 & 1.33 & 1.33 \\
\hline 22 & Chippewa River near Milan, Minn. & 05304500 & 1.39 & 1.41 & 1.39 & 1.75 & 1.83 & 1.82 \\
\hline 23 & Yellow Medicine River near Granite Falls, Minn. & 05313500 & 1.34 & 1.23 & 1.22 & 1.62 & 1.52 & 1.51 \\
\hline 24 & Redwood River near Marshall, Minn. & 05315000 & 1.39 & 1.30 & 1.32 & 1.57 & 1.51 & 1.53 \\
\hline 25 & Cottonwood River near New Ulm, Minn. & 05317000 & 1.65 & 1.63 & 1.65 & 1.78 & 1.77 & 1.77 \\
\hline 26 & Little Cottonwood River near Courtland, Minn. & 05317200 & 1.97 & 1.96 & 1.98 & 2.12 & 2.14 & 2.13 \\
\hline 27 & Watonwan River near Garden City, Minn. & 05319500 & 1.82 & 1.73 & 1.73 & 2.14 & 2.09 & 2.08 \\
\hline 28 & Le Sueur River near Rapidan, Minn. & 05320500 & 1.61 & 1.25 & 1.20 & 1.71 & 1.49 & 1.39 \\
\hline
\end{tabular}


Table 6. Absolute mean error (AME) and root mean square error (RMSE) between the annual mean potential recharge estimate from the Soil-Water-Balance (SWB) model and the annual mean base-flow estimates from the three hydrograph separation techniques for the overall calibration period (1996-2010) for 35 selected watersheds.-Continued

[USGS, U.S. Geological Survey; in/yr, inches per year; Minn., Minnesota; NA, not applicable]

\begin{tabular}{|c|c|c|c|c|c|c|c|c|}
\hline \multirow{2}{*}{$\begin{array}{l}\text { Map number } \\
\text { for watershed } \\
\text { associated with } \\
\text { streamgage } \\
\text { (fig. 6) }\end{array}$} & \multirow[b]{2}{*}{ USGS streamgage name or statistic } & \multirow[b]{2}{*}{$\begin{array}{c}\text { USGS } \\
\text { streamgage } \\
\text { number }\end{array}$} & \multicolumn{3}{|c|}{ AME (in/yr) } & \multicolumn{3}{|c|}{ RMSE (in/yr) } \\
\hline & & & $\begin{array}{l}\text { PARTa }^{a} \\
\text { (in/yr) }\end{array}$ & $\begin{array}{c}\text { HYSEP } \\
\text { fixed-interval } \\
\text { methodb }^{b}\end{array}$ & $\begin{array}{c}\text { HYSEP } \\
\text { sliding } \\
\text { methodb }\end{array}$ & $\begin{array}{l}\text { PARTa } \\
\text { (in/yr) }\end{array}$ & $\begin{array}{c}\text { HYSEP } \\
\text { fixed-interval } \\
\text { method }^{\mathrm{b}}\end{array}$ & $\begin{array}{l}\text { HYSEP } \\
\text { sliding } \\
\text { method }^{b}\end{array}$ \\
\hline 29 & High Island Creek near Henderson, Minn. & 05327000 & 1.69 & 1.57 & 1.57 & 1.94 & 1.87 & 1.86 \\
\hline 30 & Kettle River below Sandstone, Minn. & 05336700 & 2.09 & 1.86 & 1.93 & 2.35 & 2.17 & 2.24 \\
\hline 31 & Snake River near Pine City, Minn. & 05338500 & 1.79 & 1.67 & 1.74 & 2.20 & 2.10 & 2.14 \\
\hline 32 & Vermillion River near Empire, Minn. & 05345000 & 1.62 & 1.68 & 1.63 & 2.02 & 2.03 & 1.99 \\
\hline 33 & Cannon River at Welch, Minn. & 05355200 & 1.51 & 1.25 & 1.27 & 1.77 & 1.60 & 1.63 \\
\hline 34 & South Fork Zumbro River at Rochester, Minn. & 05372995 & 1.44 & 1.30 & 1.40 & 1.98 & 1.93 & 1.97 \\
\hline 35 & Cedar River near Austin, Minn. & 05457000 & 1.49 & 1.39 & 1.35 & 1.79 & 1.63 & 1.61 \\
\hline NA & Overall mean & NA & 1.57 & 1.54 & 1.54 & 1.88 & 1.87 & 1.86 \\
\hline NA & Minimum & NA & 1.09 & 1.07 & 1.08 & 1.32 & 1.33 & 1.33 \\
\hline NA & Maximum & NA & 2.09 & 2.10 & 2.08 & 2.44 & 2.57 & 2.57 \\
\hline
\end{tabular}

autledge (1998).

bSloto and Crouse (1996) 
In order to begin the second phase of the calibration process, the final lookup table values from the PEST-derived simulations were used as initial values for the manual calibration process. For an individual iteration, model parameters were altered to determine if the new set of parameter values improved the difference between the model simulations and observations. An individual iteration consisted of running the SWB model for each of the 35 watersheds separately from 1996-2010. After each iteration, the mean annual base-flow estimate (1996-2010) for each of the three hydrograph separation techniques and the mean annual potential recharge estimate (1996-2010) were calculated for all 35 watersheds. These means were used as inputs into the statistical measures for AME, RMSE, NSE, and $R^{2}$. For the NSE and $R^{2}$ measures, the observed mean $(\bar{O})$ was the mean of all 35 mean annual base-flow estimates (1996-2010) and the predicted mean $(\bar{P})$ was the mean of all 35 mean annual potential recharge estimates (1996-2010).

This process was not as straightforward as reducing the objective function during the first phase. Instead, the following conditions were considered to determine if the new parameter set was retained: (1) decreased the differences between the SWB potential recharge and the base-flow estimates for the individual watersheds, as measured by AME and RMSE (table 6); (2) improved NSE values; and (3) improved $R^{2}$ values. With improvements in the fit, such as lower AME and RMSE values and higher NSE and $R^{2}$ values, these new parameter values were retained for succeeding calibration runs. These newly retained parameter values, particular in the case of curve numbers, were compared against previous curve number method applications, including those from other published SWB models, to determine if the values seemed reasonable (Westenbroek and others, 2010; Wehmeyer and others, 2011; Metropolitan Council, 2013). Considering the vast number of combinations possible in the lookup table, the same relations set earlier by using the PAR2PAR program (Doherty, 2010) and described previously in section "Parameter Estimation" were retained. To proceed in the calibration effort, individual watersheds with high AME/RMSE values were identified and evaluated for the largest overall land cover. Generally, a critical adjustment for a few selected lookup table parameters would improve the AME and RMSE values for these selected watersheds. Obviously, this approach would potentially cause other calibrated watersheds to become less calibrated; hence, this effort required many iterations to develop the final calibrated lookup table.

The final mean potential recharge rates for the model calibration in table 4 include all the 35 individual watersheds in addition to base-flow estimates calculated by using the hydrograph separation techniques of PART, HYSEP fixed-interval method, and HYSEP sliding method. Only slight differences in the overall range of mean annual base-flow values for the 15-year period exist among the three different hydrograph separation techniques, but some larger differences did exist for individual watersheds. Mean annual base-flow values from 1996-2010 ranged from 2.92 to $7.48 \mathrm{in} / \mathrm{yr}$ as calculated by PART, 2.68 to $7.58 \mathrm{in} / \mathrm{yr}$ as calculated by the HYSEP fixed-interval method, and 2.76 to $7.50 \mathrm{in} / \mathrm{yr}$ as calculated by the HYSEP sliding method (table 4). Annual mean base-flow values for individual years for the 35 selected watersheds from 1996-2010 ranged from 0.30 to $12.45 \mathrm{in} / \mathrm{yr}$ as calculated by PART, from 0.32 to $13.13 \mathrm{in} / \mathrm{yr}$ as calculated by the HYSEP fixed-interval method, and from 0.30 to $12.80 \mathrm{in} / \mathrm{yr}$ as calculated by the HYSEP sliding method (appendix 2, table 2-1). For the calibration procedure, it was assumed that the base flow estimated by the hydrograph separation techniques reflects long-term groundwater discharge attributable to recharge.

The relative error (dimensionless) of the potential recharge estimate from the SWB model for each watershed in table 4 was calculated by using equation 7 :

$$
\text { relative error }=\frac{\text { potential recharge }-(\text { mean }, \text { threebase-flowestimates })}{\text { mean }, \text { threebase-flowestimates }}
$$

where potential recharge is the from the SWB model, in inches per year, and mean, three baseflow estimates is the mean of the three base-flow estimates determined by using hydrograph separation techniques, in inches per year. The relative errors for all 35 watersheds ranged from -0.18 to 0.24 (table 4), demonstrating a robust calibration given the number of watersheds, various watershed sizes, and the spatial extent across the State (fig. 6). Only 9 of the 35 watersheds had a relative error more than \pm 0.15 . 
The final AME and RMSE values for the calibration period (1996-2010) are summarized in table 6. This table lists the AME and RMSE values for each of the 35 individual watersheds for the three hydrograph separation techniques compared to the SWB potential recharge estimate, and also lists the overall mean AME and RMSE values. The range of values across the individual watersheds ranged from 1.07 to $2.10 \mathrm{in} / \mathrm{yr}$ for the AME and from 1.32 to $2.57 \mathrm{in} / \mathrm{yr}$ for the RMSE. The overall mean of the AME values was about $1.60 \mathrm{in} / \mathrm{yr}$, and the overall mean of the RMSE values was about $1.90 \mathrm{in} / \mathrm{yr}$ for all three hydrograph separation base-flow estimates compared to the SWB potential recharge estimates. Although the AME and RMSE values do not have as much usefulness as a relative error, $R^{2}$, or NSE for quickly evaluating the goodness-of-fit, the AME and RMSE values were a useful metric. For example, the AME and RMSE can give at least an indication of the uncertainty for the potential recharge estimates. Also, for different parts of Minnesota, the AME and RMSE values for the individual watersheds can provide additional guidance on the uncertainty of the potential recharge estimate.

The NSE between the 15-year mean annual base-flow estimates and the 15-year mean annual potential recharge estimate from the SWB model was greater than or equal to 0.80 for all three comparisons, which is greater than or equal to the threshold of acceptability for the model calibration (table 7). Another metric, the $R^{2}$, was at least 0.80 for all three comparisons (fig. 7). The linear model slope also was $>0.80$ for all three comparisons with an intercept of approximately 0.60 .

Table 7. Nash-Sutcliffe model efficiency coefficient (NSE) between annual mean base-flow estimates from three different hydrograph separation techniques and the annual mean potential recharge estimate from the Soil-Water-Balance (SWB) model.

\begin{tabular}{ll}
\hline \multicolumn{1}{c}{ Hydrograph separation technique } & NSE \\
\hline PART $^{\mathrm{a}}$ & 0.80 \\
HYSEP fixed-interval method $^{\mathrm{b}}$ & 0.86 \\
HYSEP sliding method $^{\mathrm{b}}$ & 0.86 \\
\hline
\end{tabular}

${ }^{a}$ Rutledge (1998).

bSloto and Crouse (1996).
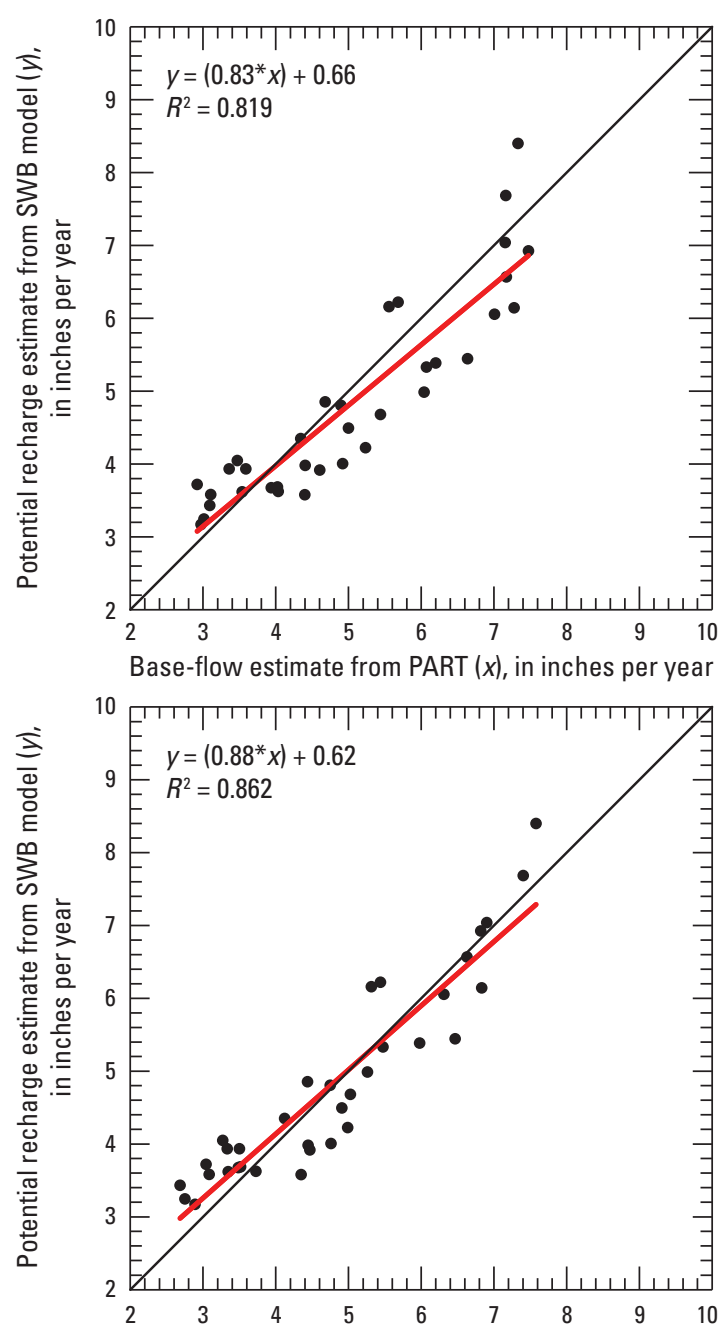

Base-flow estimate from HYSEP fixed-interval $(x)$, in inches per year

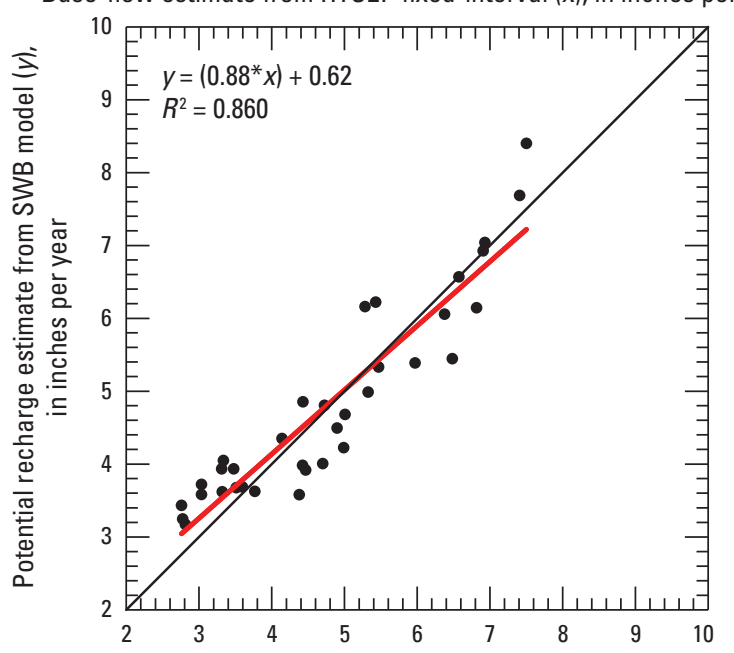

Base-flow estimate from HYSEP sliding method $(x)$, in inches per year

Figure 7. Relation between 15-year mean base-flow estimates from three different hydrograph separation techniques and the 15-year mean potential recharge estimates from the Soil-WaterBalance (SWB) model for 35 selected watersheds, along with linear trendline (in red), 1:1 line, linear model equation, and the coefficient of determination $\left(R^{2}\right)$. 


\section{Potential Groundwater Recharge Estimates}

Following calibration, the SWB model was run for the years 1996 through 2010 to simulate potential groundwater recharge rates for Minnesota, with the years 1994 to 1995 used to initialize soil-moisture values. Annual mean potential recharge estimates (that is, the means for individual years from 1996 through 2010) and 15-year mean annual potential recharge estimates (that is, the mean for the 15-year period 1996-2010) were determined for Minnesota based on the SWB model results.

\section{Annual Mean Potential Recharge Estimates}

As mentioned previously in the section "Model Limitations and Assumptions," lag time was not accounted for in the SWB model; recharge was assumed as instantaneous within the daily time step. Also, as mentioned previously in that section, the 15-year mean annual potential recharge estimate (1996-2010) is the most reliable estimate (described in the next section, "Mean Annual Potential Recharge Estimates") because of the lag-time issue with the annual potential recharge estimates. To further illustrate that the annual mean recharge estimates (that is, the means for individual years from 1996 through 2010) were not as suitable for usage as the 15-year mean annual potential recharge estimates for the overall period (fig. 7), the annual mean base-flow estimates from the three different hydrograph separation techniques (PART, HYSEP fixed-interval method, and HYSEP sliding method) were compared to the annual mean potential recharge estimates from the SWB model (fig. 8) for the 35 selected watersheds. Although the relation for the three comparisons was nearly linear, the $R^{2}$ values were between 0.526 and 0.533 . Although the relations for the annual mean potential recharge estimates are not as strong as the relation for the overall period, the annual mean potential recharge maps are useful for comparing years with high recharge rates with years with low recharge rates. The recharge maps are presented as figures 3-1 (1996) through 3-15 (2010) in appendix 3.

Annual mean potential recharge rates had a much wider range, with maximum rates as high as $27.2 \mathrm{in} / \mathrm{yr}$ (appendix 3), in comparison to the maximum mean annual recharge rate of $17.8 \mathrm{in} / \mathrm{yr}$ for the overall period mean described in the next section, "Mean Annual Potential Recharge Estimates." The highest annual mean recharge across the State was in 2010 (fig. 3-15), and the lowest mean recharge was in 2003 (fig. 3-8). Although precipitation variability partially explained the annual differences in potential recharge estimates, precipitation alone did not account for these differences, and other factors such as antecedent moisture conditions likely were important. Also, because differences in precipitation gradients across the State can vary from year to year, the dominant land cover and hydrologic soil group

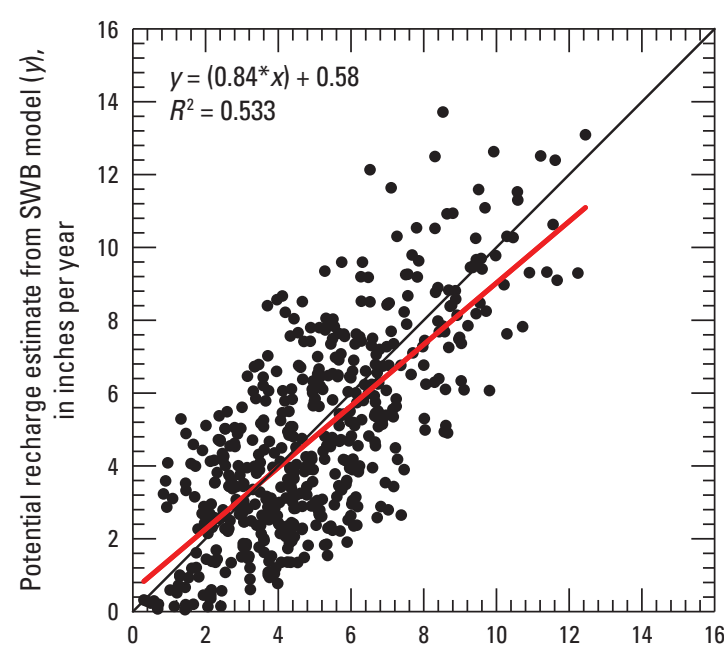

Base-flow estimate from PART $(x)$, in inches per year

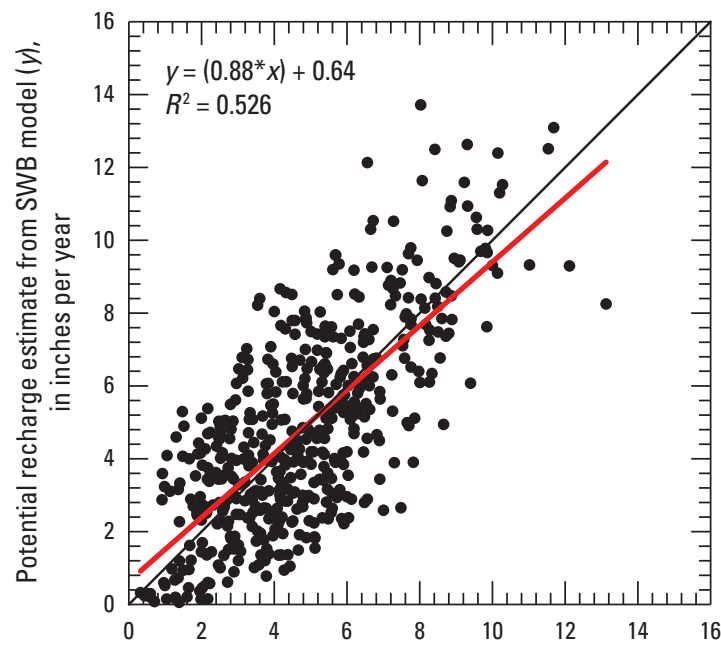

Base-flow estimate from HYSEP fixed-interval $(x)$, in inches per year

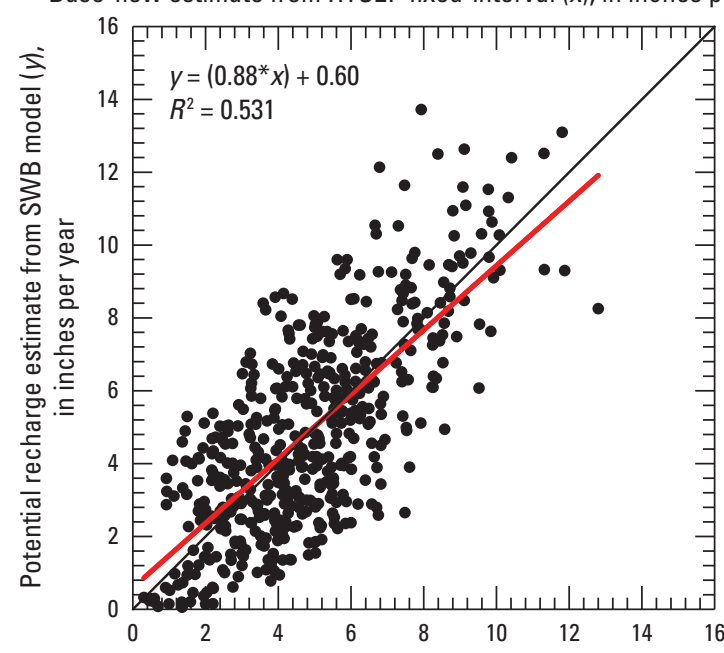

Base-flow estimate from HYSEP sliding method $(x)$, in inches per year

Figure 8. Relation between annual mean base-flow estimates from three different hydrograph separation techniques and the annual mean potential recharge estimates from the Soil-WaterBalance (SWB) model for 35 selected watersheds, along with linear trendline (in red), 1:1 line, linear model equation, and the coefficient of determination $\left(R^{2}\right)$. 
combinations for a particular region had a large effect on the resulting potential recharge value. During 1996-2010, April had the greatest mean monthly potential recharge compared to all other months, accounting for a mean of 30 percent of annual potential recharge in this single month.

\section{Mean Annual Potential Recharge Estimates}

The statewide 15-year mean annual potential recharge rate from 1996-2010 was $4.9 \mathrm{in} / \mathrm{yr}$. The mean annual potential recharge estimates across Minnesota at a 1-km resolution for the simulation period ranged from $<0.1$ to $17.8 \mathrm{in} / \mathrm{yr}$ (fig. 9). Some of the lowest potential recharge rates for the simulation period (generally between 1.0 and $1.5 \mathrm{in} / \mathrm{yr}$ ) were in the Red River of the North Basin of northwestern Minnesota (figs. 9 and 10). Not only is this the driest part of the State based on mean annual gross precipitation (fig. 2), but this area also has thick, clayey soils that are restrictive to infiltration as indicated by the high concentration of hydrologic soil groups $\mathrm{C}$ and $\mathrm{D}$ (fig. 4). The highest potential recharge rates were estimated in northeastern Minnesota and the Anoka Sand Plain (figs. 9 and 10). These were likely controlled by the high precipitation rates (fig. 2) and the low available soil-water capacity (fig. 5). Eighty-eight percent of the mean annual potential recharge rates (by grid cell) were between 2 and $8 \mathrm{in} / \mathrm{yr}$ from 1996-2010 (fig. 11). Only about 3 percent of all the potential recharge estimates (by grid cell) were less than $2 \mathrm{in} / \mathrm{yr}$, and 9 percent were greater than $8 \mathrm{in} / \mathrm{yr}$ (fig. 11).

Overall, potential recharge rates increased from west to east across Minnesota, which was partially a reflection of the precipitation gradient (fig. 2). The mean annual potential recharge estimate from the SWB model was approximately 30 percent of the mean annual gross precipitation. The correlation is moderate between mean annual gross precipitation and the potential recharge estimates from the SWB model for the entire period for the 35 selected watersheds used for calibration, with an $R^{2}$ value of 0.512 (fig. 12). However, this $R^{2}$ value is weaker than those in the previous comparisons between the base-flow estimates from the hydrograph separation techniques and the potential recharge estimates from the SWB model (fig. 7), which were equal to or greater than an $R^{2}$ of 0.8 . This indicates that other inputs to the SWB model, not just precipitation, were important in explaining potential recharge estimate variations across the State. For example, potential recharge rates for most of the State were between 10 to 25 percent of the gross precipitation, with some areas with rates outside this range (fig. 13). The Anoka Sand Plain (fig. 10) and a large part of northeastern Minnesota had potential recharge rates that ranged from 25 to 40 percent of gross precipitation (fig. 13). The Anoka Sand Plain consists of porous sandy soils and most of the area was in hydrologic soil group A, which has a high infiltration capacity (Minnesota Department of Natural Resources, 1993). In northeastern Minnesota, land cover included a substantial amount of deciduous and mixed forests (fig. 3), in addition to having low available soil-water capacity (fig. 5). Conversely, northwestern Minnesota has recharge rates as low as 5 percent of gross precipitation. For the TCMA (fig. 10), potential recharge rates were more complex, ranging from $<2.0 \mathrm{in} / \mathrm{yr}$ to greater than $15.0 \mathrm{in} / \mathrm{yr}$. This wide variability reflects the various land-cover types in the TCMA, from developed, high-intensity land use to regional parks with expansive deciduous forest, open park space, and golf courses.

The total area of active cells in the Minnesota SWB model and the mean potential recharge estimates from 1996-2010 are shown in table 8 by land-cover class and hydrologic soil group. No potential recharge rate is given for the open water category, as recharge for open water cells was not considered by the SWB code. It was assumed that open water drains through surface-water features rather than recharging the underlying aquifers. The statewide areaweighted mean potential recharge ranged from $4.16 \mathrm{in} / \mathrm{yr}$ for cultivated crops to $6.93 \mathrm{in} / \mathrm{yr}$ for evergreen forests. Among urban category land-cover classes 21 through 24, land-cover class 23 (developed, medium intensity) had the highest potential recharge rate of $6.10 \mathrm{in} / \mathrm{yr}$ although less than 0.4 percent $\left(784 \mathrm{~km}^{2}\right.$ of total $201,265 \mathrm{~km}^{2}$ ) of active cells were this land-cover class. The highest potential recharge estimates of all groups, where broken out by the different hydrologic soil groups, were urban land classes of 22 and 24 underlain by hydrologic soil group A; however, these groups had small land-cover areas. Pasture/hay (5.02 in/yr), woody wetlands (5.07 in/yr), and herbaceous wetlands (4.20 in/yr), along with cultivated crops, had some of the lowest potential recharge estimates compared to most of the other groups. Considering that these four land-cover classes dominated over the State (approximately 70 percent of the active model cells), the overall statewide mean annual recharge rate of $4.9 \mathrm{in} / \mathrm{yr}$ was not unexpected. 


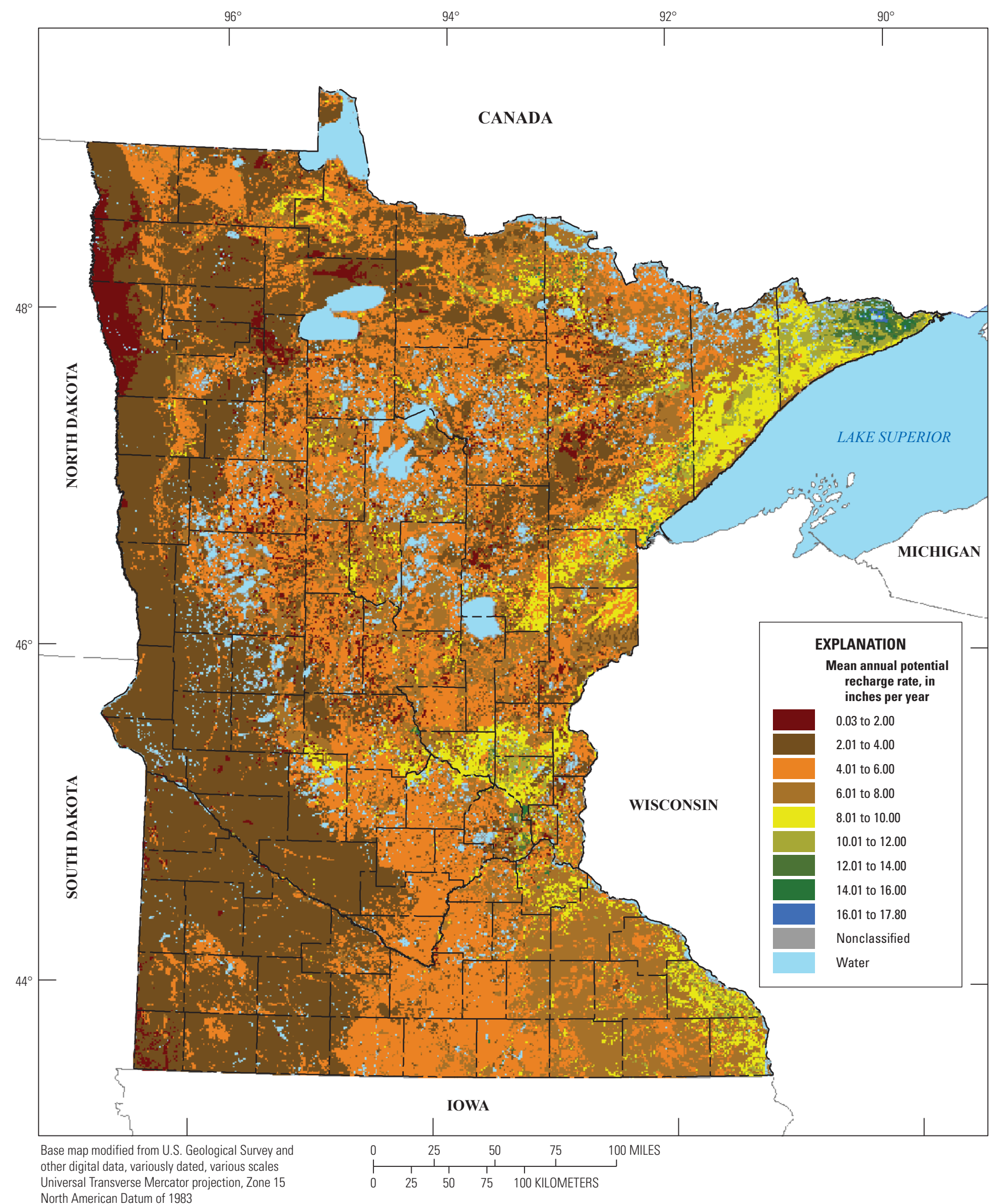

Figure 9. Mean annual potential recharge rates from 1996-2010 based on results from the Soil-Water-Balance (SWB) model for Minnesota. 


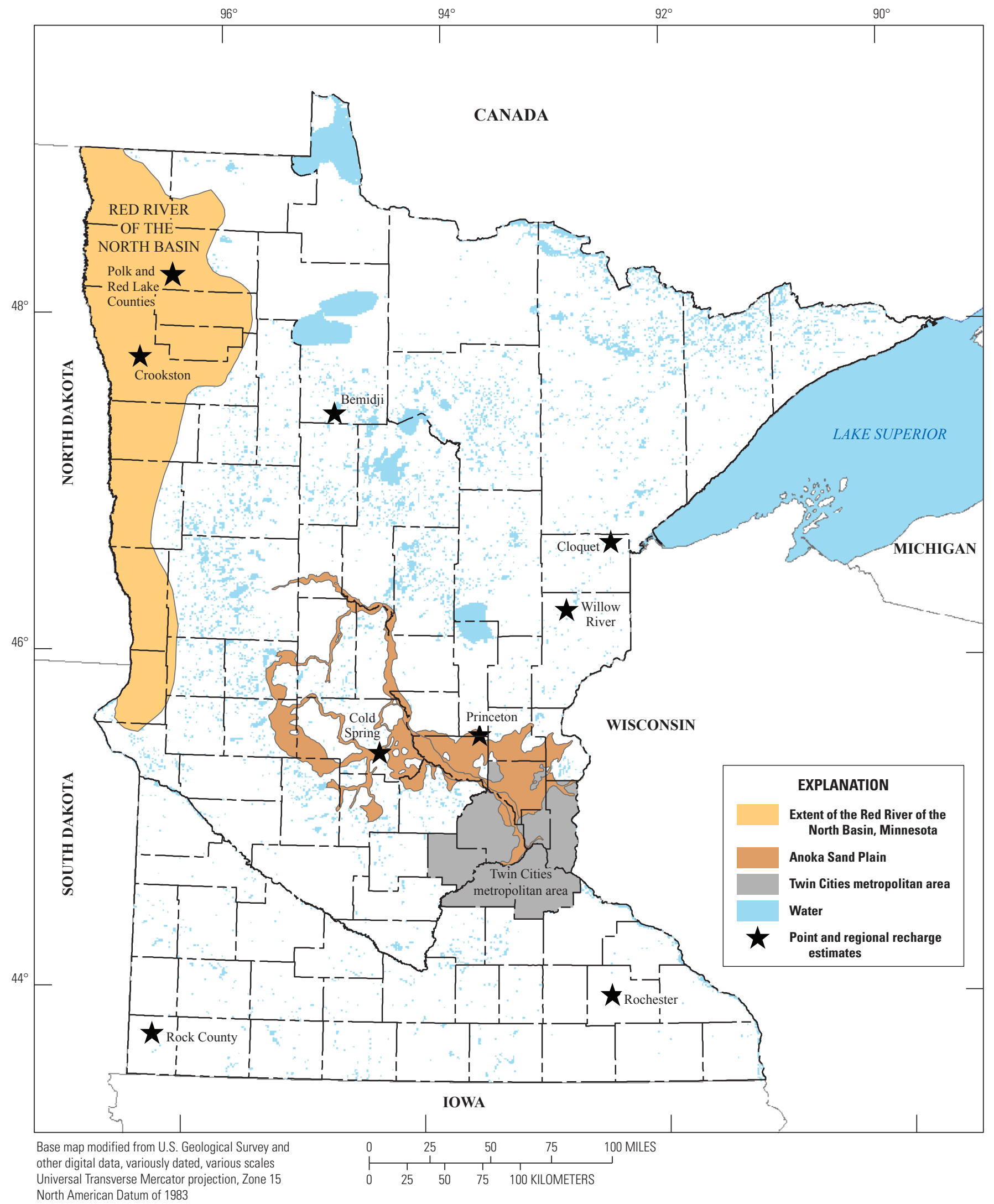

Figure 10. Locations of point and regional recharge estimates referred to in text and table 9 . 
Mean potential recharge rates by hydrologic soil group were a little more surprising. For example, the statewide area-weighted mean potential recharge rate for hydrologic soil group D, typically known for very slow infiltration rates (Cronshey and others, 1986), was greater than rates for hydrologic soil groups B and C. However, this result was not unreasonable given that the root-zone depths were shallower in this group and that much of the geographical extent of hydrologic soil group D was in northeastern Minnesota, where precipitation rates were the highest. Also, the predominant land-cover class in northeastern Minnesota was one of the three forest classes, all of which had high mean potential recharge rates.
The similarity in potential recharge rates between hydrologic soil groups $\mathrm{B}$ and $\mathrm{C}$ can be explained by the countering effects of the runoff curve number and the root-zone depths; the greater curve runoff numbers for soil group $\mathrm{C}$ soils were counterbalanced by the shallower root-zone depths (Thornthwaite and Mather, 1957) for soil group C soils. On the two ends of the spectrum, hydrologic soil group A had the highest overall potential recharge rate of $6.48 \mathrm{in} / \mathrm{yr}$, and the organic hydrologic soil group had the lowest overall potential recharge rate of $3.57 \mathrm{in} / \mathrm{yr}$. This low potential recharge rate for organic soils is likely due to the greater soil-water capacity of organic soils compared to non-organic soils.

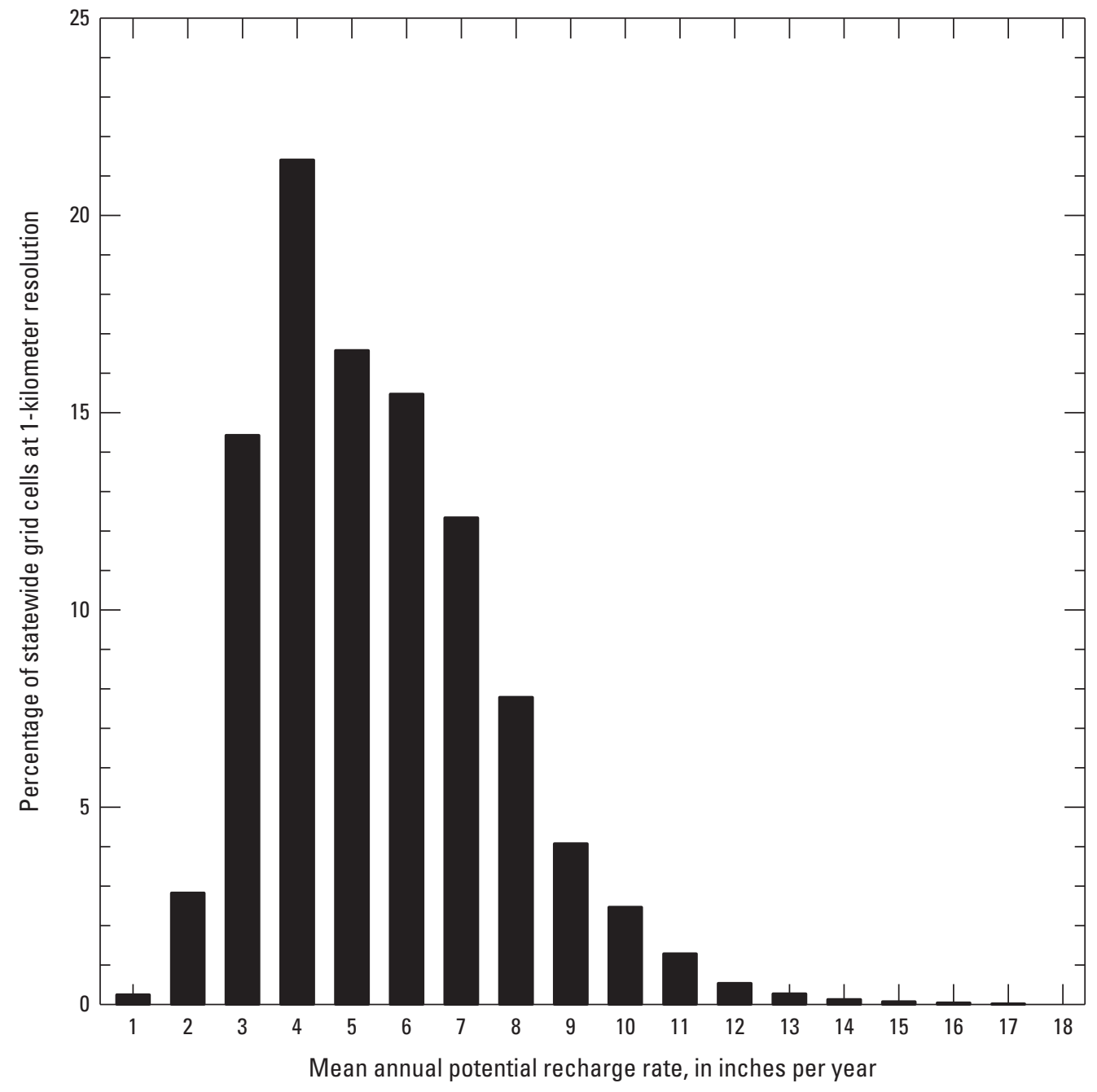

Figure 11. Histogram (by percent) of the mean annual potential recharge rates from the Soil-WaterBalance model from 1996-2010 for Minnesota. 


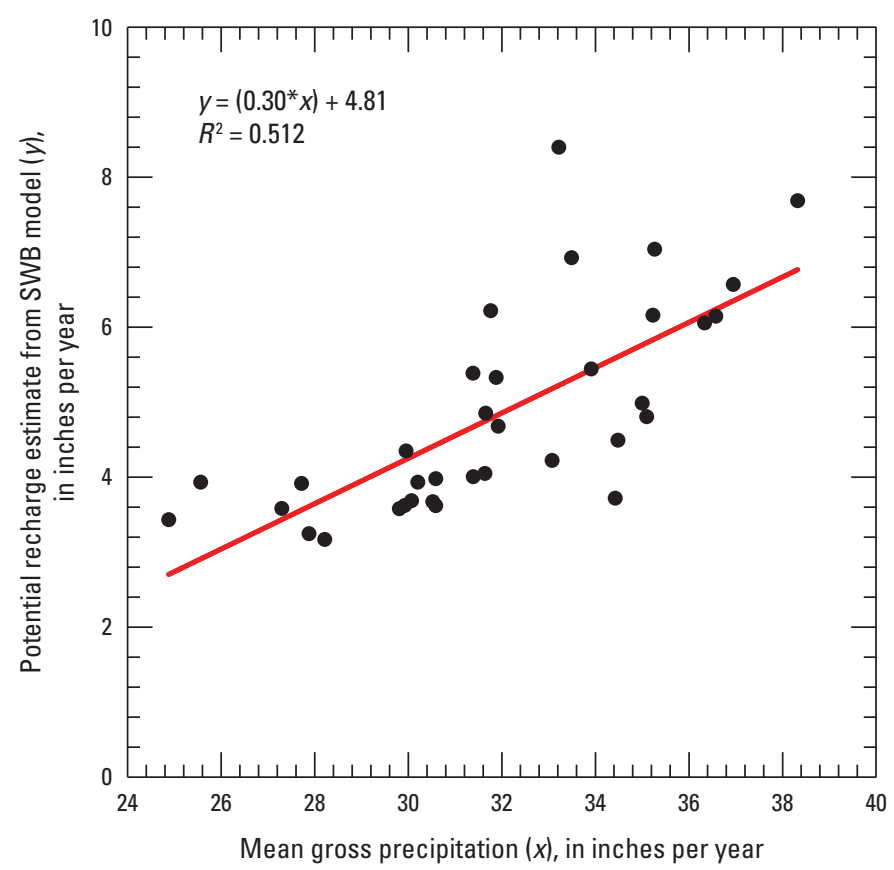

Figure 12. Relation between mean annual gross precipitation and the mean annual potential recharge estimates from the Soil-Water-Balance (SWB) model for the overall calibration period (1996-2010) for the 35 selected watersheds used for model calibration.

\section{Comparison to the Regional Regression Recharge Model}

As mentioned previously in the section "Previous Studies," Delin and others (2007) produced mean recharge rates to surficial materials, from 1971 through 2000, for the State of Minnesota. Delin and others (2007) and Lorenz and Delin (2007) regionalized RORA watershed-scale recharge estimates (Rutledge, 1998) based on a regression model that incorporated soil and meteorological information in addition to mean annual precipitation. Soil information was incorporated in a specific yield estimate; specific yield can be related to soil texture and is a corollary to the usage of the hydrologic soil groups in the SWB model. Meteorological data were growing degree days (GDD) in lieu of an explicit calculation of ET. A statewide recharge map, similar to the map of potential recharge estimates from the SWB model shown in figure 9, was generated by applying the regression model, known as the regional regression recharge (RRR) model, to the State (appendix 4).

The RRR and SWB models only partially overlap temporally, as the RRR model was based on mean precipitation and GDD from 1971 through 2000. The best comparison would be to run both models for the same time period, but would require redefining the RRR model for the same time period as the SWB model (or vice versa). However, a comparison between the two models is warranted given the substantial usage of the recharge estimates from the RRR model. To make this comparison, the polygon map of recharge estimates from the RRR model available from the Minnesota Department of Natural Resources (Minnesota Department of Natural Resources, 2007) was converted to a 1-km grid. A difference map was computed by subtracting the recharge estimates for the RRR model from the potential recharge estimates for the SWB model (fig. 14). This difference map shows that the recharge estimates generally were within $3 \mathrm{in} / \mathrm{yr}$ between the RRR model and SWB model. Few parts of the State had differences between the SWB model and RRR model that were $>3.0 \mathrm{in} / \mathrm{yr}$ (that is, higher recharge rates from the SWB model than from the RRR model), with the exception of northeastern Minnesota. In contrast, approximately 59 percent of the total area, particularly in north-central and parts of northeastern Minnesota, had negative differences indicating that the RRR model estimated more recharge than did the SWB model for these areas. Of the total area with negative differences, 13 percent had a difference greater than $3 \mathrm{in} / \mathrm{yr}$ estimated for the RRR model compared to the SWB model. One potential explanation for some of the negative difference areas was that the available soil-water capacity for these areas commonly is higher (fig. 5), a factor not accounted for in the RRR model. This explanation is supported because much of the area with higher SWB recharge estimates in comparison to the RRR model had low available soil-water capacity. Another potential explanation was that although the GDD do account for a primary component of ET, the GDD are not as robust as the daily calculation of water-balance components (including potential and actual ET) in the SWB model. Finally, the land-cover class for much of the area where the estimated recharge was higher for the RRR model than the SWB model was one of the two wetland groups, both of which generally had lower mean potential recharge than other land-cover classes.

\section{Comparison to Other Recharge Estimates}

Potential recharge estimates from the SWB model also were compared to other point and regional recharge estimates (table 9). Several studies scattered across Minnesota that used either water-table fluctuation methods or a groundwater-flow model to estimate recharge rates are shown in table 9. In most cases, the potential recharge estimate from the SWB model was in the same range as the other recharge estimates. For example, Delin (1991) determined estimated recharge rates of 3.0 to $6.0 \mathrm{in} / \mathrm{yr}$ to the uppermost unit of the Prairie du Chien Group based on calibrated results of a three-dimensional groundwater-flow model. Recharge estimates reported for the same areal extent in the SWB model, covering an area north/northeast of Rochester, Minnesota, ranged from 1.7 to $7.4 \mathrm{in} / \mathrm{yr}$. Other SWB potential recharge estimates generally were within the same range as previous recharge estimates 


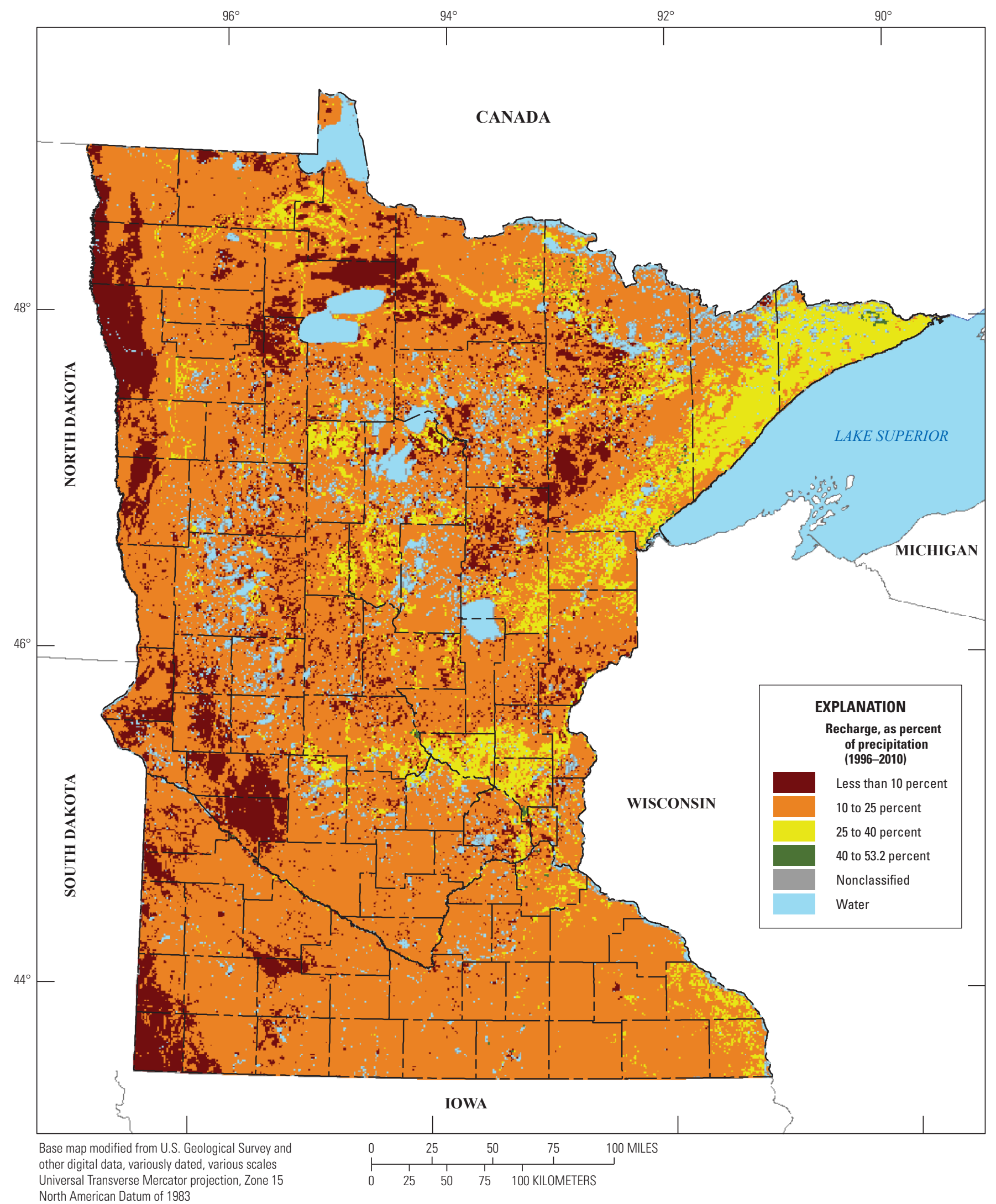

Figure 13. Mean annual potential recharge estimates from the Soil-Water-Balance (SWB) model, shown as a percentage of mean annual gross precipitation from 1996-2010. 
Table 8. Total area of active cells in Soil-Water-Balance (SWB) model and mean annual potential recharge estimates, by land-cover class and hydrologic soil group, from 1996-2010.

[The statewide mean by land cover and hydrologic soil group, in italics, is an area-weighted mean potential recharge estimate for the entire State for active cells. NA, not applicable]

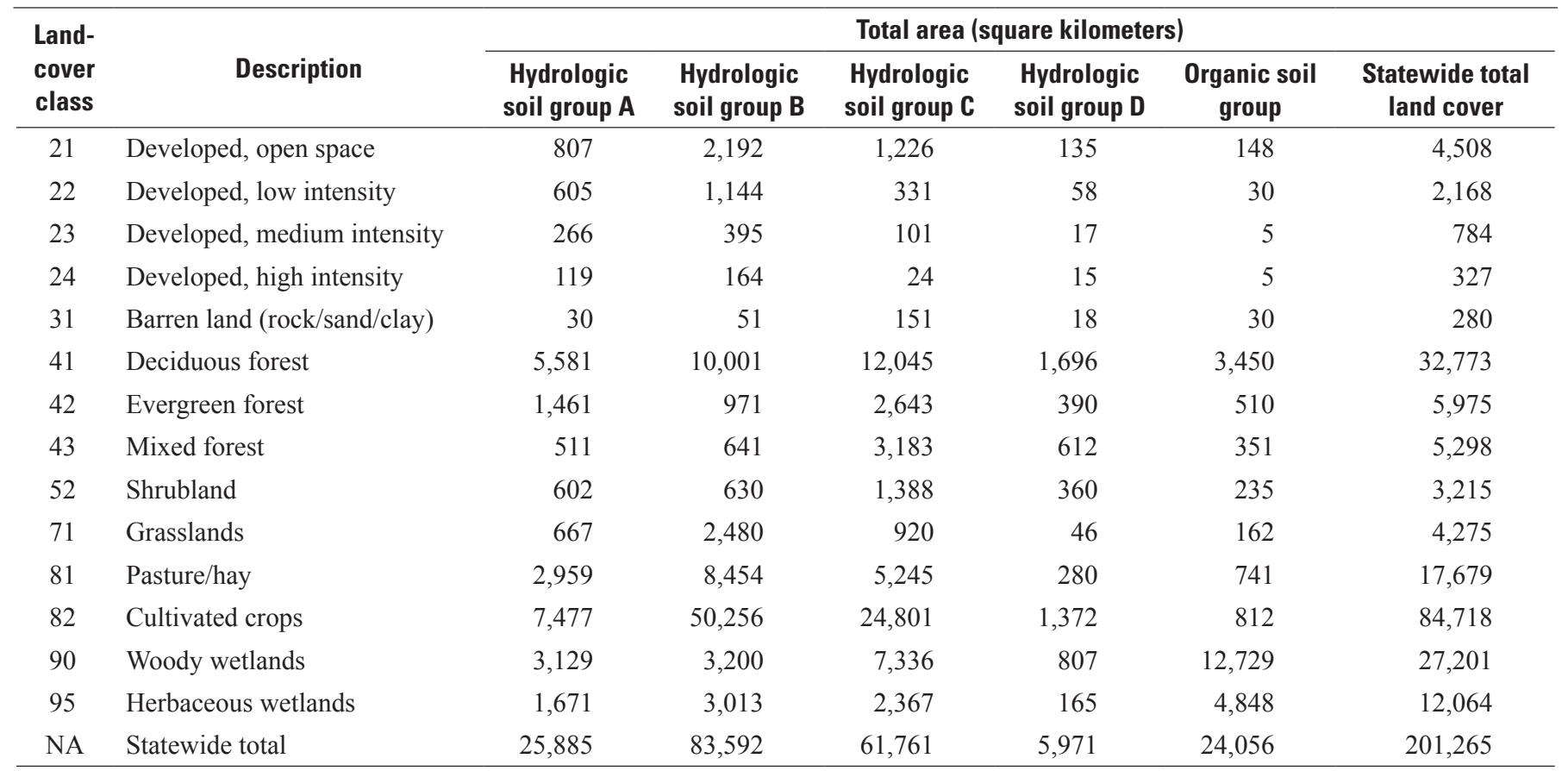

\begin{tabular}{|c|c|c|c|c|c|c|c|}
\hline \multirow[b]{2}{*}{$\begin{array}{l}\text { Land- } \\
\text { cover } \\
\text { class }\end{array}$} & \multirow[b]{2}{*}{ Description } & \multicolumn{6}{|c|}{ Mean annual potential recharge (inches per year) } \\
\hline & & $\begin{array}{l}\text { Hydrologic } \\
\text { soil group A }\end{array}$ & $\begin{array}{l}\text { Hydrologic } \\
\text { soil group B }\end{array}$ & $\begin{array}{l}\text { Hydrologic } \\
\text { soil group C }\end{array}$ & $\begin{array}{l}\text { Hydrologic } \\
\text { soil group D }\end{array}$ & $\begin{array}{l}\text { Organic soil } \\
\text { group }\end{array}$ & $\begin{array}{l}\text { Statewide area- } \\
\text { weighted mean, by } \\
\text { land-cover class }\end{array}$ \\
\hline 21 & Developed, open space & 6.72 & 4.78 & 4.42 & 5.29 & 3.89 & 5.02 \\
\hline 22 & Developed, low intensity & 7.84 & 5.41 & 4.91 & 5.54 & 3.62 & 5.99 \\
\hline 23 & Developed, medium intensity & 7.70 & 5.39 & 4.86 & 5.47 & 4.79 & 6.10 \\
\hline 24 & Developed, high intensity & 7.88 & 4.40 & 4.63 & 4.08 & 6.04 & 5.69 \\
\hline 31 & Barren land (rock/sand/clay) & 6.63 & 4.70 & 5.47 & 3.76 & 2.03 & 4.98 \\
\hline 41 & Deciduous forest & 6.48 & 5.85 & 6.27 & 6.94 & 4.43 & 6.02 \\
\hline 42 & Evergreen forest & 6.55 & 6.82 & 7.62 & 7.73 & 4.07 & 6.93 \\
\hline 43 & Mixed forest & 6.71 & 6.88 & 6.96 & 6.89 & 3.99 & 6.72 \\
\hline 52 & Shrubland & 6.70 & 6.21 & 6.88 & 7.09 & 4.26 & 6.55 \\
\hline 71 & Grasslands & 6.69 & 5.36 & 4.69 & 7.09 & 3.25 & 5.36 \\
\hline 81 & Pasture/hay & 6.33 & 4.90 & 4.73 & 5.19 & 3.14 & 5.02 \\
\hline 82 & Cultivated crops & 6.06 & 4.32 & 3.38 & 3.13 & 3.19 & 4.16 \\
\hline 90 & Woody wetlands & 7.00 & 5.88 & 6.50 & 6.00 & 3.52 & 5.07 \\
\hline 95 & Herbaceous wetlands & 6.42 & 4.09 & 4.92 & 5.33 & 3.12 & 4.20 \\
\hline NA & $\begin{array}{l}\text { Statewide area-weighted mean, } \\
\text { by hydrologic soil group }\end{array}$ & 6.48 & 4.74 & 4.99 & 5.80 & 3.57 & 4.93 \\
\hline
\end{tabular}




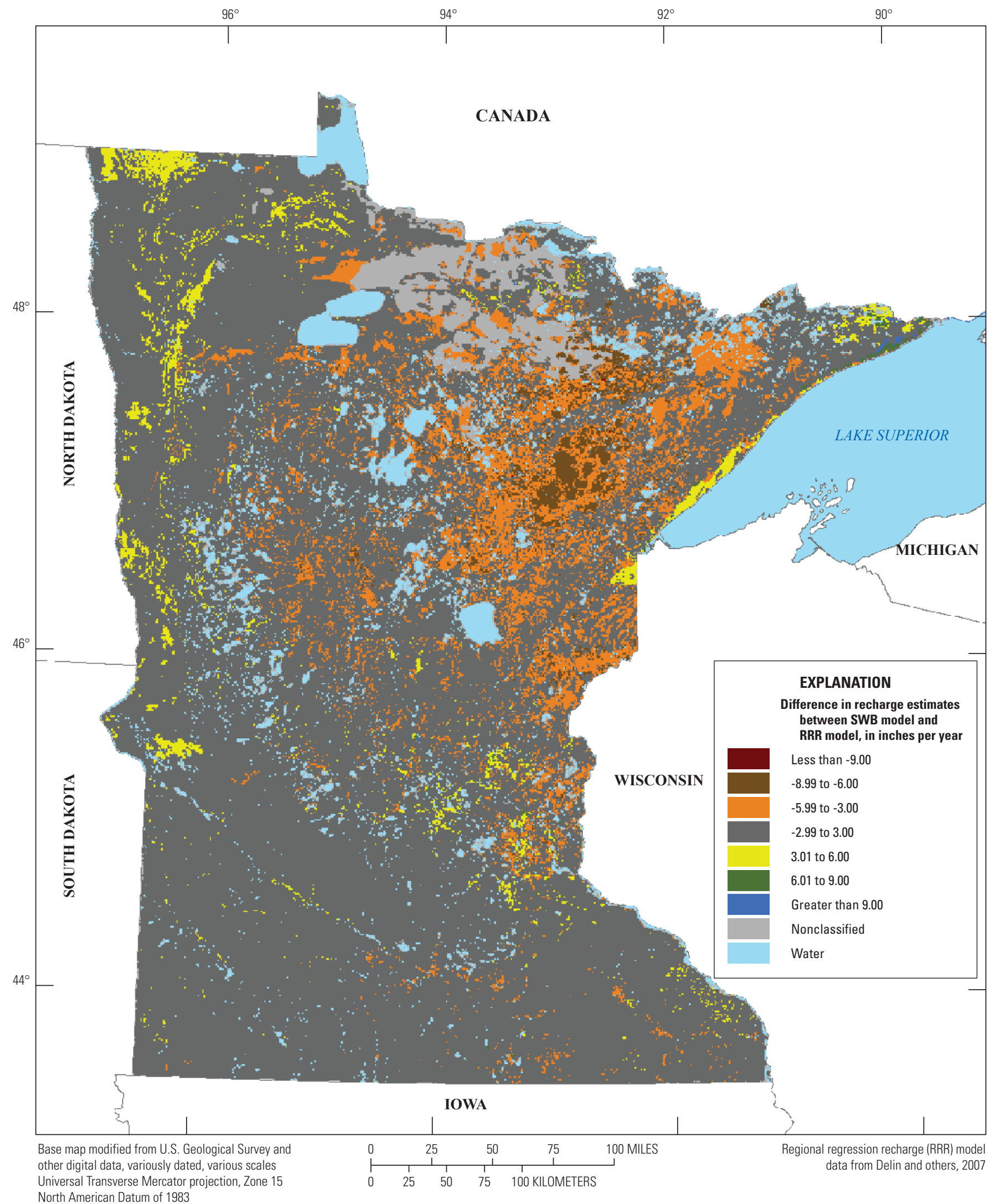

Figure 14. Difference between mean annual potential recharge estimates from the Soil-Water-Balance (SWB) model for 1996-2010 and recharge estimates from the regional regression recharge (RRR) model for 1971-2000 (Delin and others, 2007). [A negative value indicates that the RRR model recharge rate was greater than the SWB model recharge rate.] 
Table 9. Comparison of selected point and regional recharge estimates to potential recharge estimates from the Soil-Water-Balance (SWB) model.

[Minn., Minnesota; WTF, water-table fluctuation; GWM, groundwater-flow model; T/H, tritium-helium; UZWB, unsaturated zone water balance; ,-- not available]

\begin{tabular}{|c|c|c|c|c|c|}
\hline \multirow[t]{2}{*}{ Reference } & \multirow[t]{2}{*}{$\begin{array}{l}\text { Areal extent of recharge estimate } \\
\text { (nature of aquifer materials) }\end{array}$} & \multirow{2}{*}{$\begin{array}{l}\text { Recharge } \\
\text { estimatation } \\
\text { method }\end{array}$} & \multirow[t]{2}{*}{$\begin{array}{l}\text { Years of } \\
\text { measurement } \\
\text { (if available) }\end{array}$} & $\begin{array}{l}\text { Point and regional } \\
\text { recharge estimate }\end{array}$ & $\begin{array}{l}\text { Potential recharge } \\
\text { estimate from } \\
\text { SWB model }\end{array}$ \\
\hline & & & & \multicolumn{2}{|c|}{ (inches per year) } \\
\hline $\begin{array}{l}\text { Cowdery and } \\
\text { others (2007) }\end{array}$ & $\begin{array}{l}\text { East of Crookston, Minn., Glacial Ridge } \\
\quad \text { (glacial drift aquifer) }\end{array}$ & WTF & $2003-05$ & $11.0-25.1$ & $0.0-22.8$ \\
\hline $\begin{array}{l}\text { Delin and others } \\
\text { (2000) }\end{array}$ & $\begin{array}{l}\text { South of Princeton, Minn. } \\
\text { (glacial drift aquifer, lowland site) }\end{array}$ & WTF & $1992-95$ & $4.3-10.2$ & $8.7-9.3$ \\
\hline $\begin{array}{l}\text { Essaid and others } \\
\qquad(2003)\end{array}$ & $\begin{array}{l}\text { Bemidji, Minn., crude-oil spill site } \\
\quad \text { (glacial drift aquifer) }\end{array}$ & $\begin{array}{l}\text { WTF, T/H, } \\
\text { UZWB }\end{array}$ & -- & $2.8-11.8$ & 5.9 \\
\hline Lindgren (2001) & $\begin{array}{l}\text { Cold Spring, Minn., also surrounding } \\
\text { area (glacial till and outwash } \\
\text { sand/gravels) }\end{array}$ & WTF & 1999 & $5.3-8.6$ & $4.4-9.0$ \\
\hline $\begin{array}{l}\text { Lindgren and } \\
\quad \text { Landon (2000) }\end{array}$ & $\begin{array}{l}\text { Rock County, Minn., Rock River Valley } \\
\quad \text { (glacial outwash sand/gravels) }\end{array}$ & WTF & 1995 & $2.9-8.1$ & $1.8-2.4$ \\
\hline Lindholm (1980) & $\begin{array}{l}\text { Benton and Sherburne Counties, Anoka } \\
\text { Sand Plain } \\
\text { (glacial outwash sand/gravels) }\end{array}$ & WTF & $1970-78$ & $\begin{array}{c}8.0 \\
\text { (average) }\end{array}$ & $\begin{array}{c}7.12 \\
\text { (average) }\end{array}$ \\
\hline Myette (1986) & $\begin{array}{l}\text { Willow River, Minn. } \\
\text { (glacial outwash sand/gravels) }\end{array}$ & WTF & -- & 4.5 & 7.3 \\
\hline $\begin{array}{l}\text { Soukup and others } \\
\text { (1984) }\end{array}$ & $\begin{array}{l}\text { Red River Valley, Wilkins County } \\
\quad \text { (glacial drift aquifers) }\end{array}$ & WTF & $1973-80$ & $3.4-8.5$ & $1.0-4.8$ \\
\hline $\begin{array}{l}\text { Stark and others } \\
\text { (1991) }\end{array}$ & $\begin{array}{l}\text { Bemidji, Minn., crude-oil spill site } \\
\quad \text { (glacial drift aquifer) }\end{array}$ & GWM & $1986-87$ & $4.0-8.0$ & 5.9 \\
\hline
\end{tabular}


based on the water-table fluctuation method, such as Delin and others (2000), Lindgren (2001), Lindholm (1980), Ruhl and others (2002), Schoenberg (1998), and Stark and others (1991). Recharge estimates from Lindgren (1996) using the water-table fluctuation method had a greater range than the estimates from the SWB model. Recharge estimates from Cowdery and others (2007) for 2003-05 had a greater range, 11.0 to $25.1 \mathrm{in} / \mathrm{yr}$, than estimates from the SWB model. In this particular case, year to year comparisons were made because the years fell into the period of record for the SWB model. For the SWB model, the recharge estimates ranged from 0.0 to $5.3 \mathrm{in} / \mathrm{yr}$ for 2003 , from 1.3 to $13.1 \mathrm{in} / \mathrm{yr}$ for 2004 , and from 0.0 to $22.8 \mathrm{in} / \mathrm{yr}$ for 2005. Another notable deviation from previous results was for central Rock County located in southwestern Minnesota, where the estimated potential recharge estimate from the SWB model ranged from 1.8 to $2.4 \mathrm{in} / \mathrm{yr}$, and the recharge estimate from Lindgren and Landon (2000) ranged from 2.9 to $8.1 \mathrm{in} / \mathrm{yr}$.

Two other regional simulations, Neff and others (2006) and Arnold and others (2002), were compared to the SWB model. Recharge estimates from the SWB compared favorably to Neff and others (2006), who provided recharge estimates for parts of northeastern Minnesota along Lake Superior. The recharge estimates by Neff and others (2006) ranged from 4.0 to $11.9 \mathrm{in} / \mathrm{yr}$, and the potential recharge estimates from the SWB model for the same area ranged from 2.0 to $12.0 \mathrm{in} / \mathrm{yr}$, with a few small pockets with estimates $>12.0 \mathrm{in} / \mathrm{yr}$ in the $\mathrm{SWB}$ model near the Minnesota-Canada border. Arnold and others (2000) reported recharge estimates from two different methods, one method from the water balance component of the soil and water assessment (SWAT) model and a second method derived from a hybrid hydrograph separation technique. Both estimates from Arnold and others (2000) were $<6.0 \mathrm{in} / \mathrm{yr}$ for the southeastern region of Minnesota, which are less than the upper range of estimates from the SWB model of 2.0 to $>12.0 \mathrm{in} / \mathrm{yr}$.

\section{Sensitivity Analysis}

A sensitivity analysis was completed on the final calibrated SWB model to understand the effects of controlled departures in the calibrated lookup table and control file on the model results. Only a subset of the lookup table parameters was examined in the sensitivity analysis. Any land-cover class that had less than or equal to 2 percent of the total land cover, excluding open water, across Minnesota (table 1) was ruled out as part of the sensitivity analysis, narrowing down the list to eight land-cover classes. Maximum recharge rates and interception storage were not included as part of the sensitivity analysis because a previous SWB study (Aurand, 2013) determined that SWB was not very sensitive to changes in the maximum recharge rates, and interception storage rates were shown to be insensitive in figure 22 of Westenbroek and others (2010). For the remaining two lookup table groups, runoff curve numbers and the rootzone depth, the calibrated SWB model was run for each unique combination of land-cover class and hydrologic soil group. Each lookup parameter was increased by 20 percent and decreased by 20 percent, and then compared to the calibrated SWB model.

Results are presented in table 10 as the relative percent sensitivity from the calibrated value. The calibrated value was the mean annual potential recharge estimate for the overall domain (Minnesota). Each table cell in the upper part of table 10 contains three values: the calibrated curve number (from table 3), the adjusted curve number, and relative percent sensitivity. Each cell in the lower part of table 10 contains three values: the calibrated root-zone depth (from table 3), the adjusted root-zone depth, and relative percent sensitivity. The relative percent sensitivity, as computed by equation 8 (Aurand, 2013), can be used to evaluate the percent change in the model results to overall percent change in the parameter:

$$
\text { Relative percent sensitivity }=\frac{\text { Percent change in model results }}{\text { Percent change } \text { in parameter }} \times 100
$$

In some cases, an increase or decrease by 20 percent in the curve number would put the curve number outside the bounds of 30 to 100 , which are the practical limits validated by other curve 
Table 10. Summary of relative percent sensitivity analysis from the base value in the lookup table of the calibrated Soil-Water-Balance (SWB) model. Each parameter was separately adjusted by plus or minus 20 percent to calculate the relative percent sensitivity.

[Bold text indcates lookup table parameters with greater than 2 percent relative percent sensitivity from the calibrated lookup table parameter]

\begin{tabular}{|c|c|c|c|c|c|c|c|}
\hline $\begin{array}{l}\text { Land-cover } \\
\quad \text { class }\end{array}$ & Description & $\begin{array}{l}\text { Input, in percent change } \\
\text { from calibrated value }\end{array}$ & $\begin{array}{l}\text { Hydrologic } \\
\text { soil group A }\end{array}$ & $\begin{array}{l}\text { Hydrologic } \\
\text { soil group B }\end{array}$ & $\begin{array}{l}\text { Hydrologic } \\
\text { soil group C }\end{array}$ & $\begin{array}{l}\text { Hydrologic } \\
\text { soil group D }\end{array}$ & $\begin{array}{l}\text { Organic } \\
\text { soil group }\end{array}$ \\
\hline \multicolumn{8}{|c|}{ Curve number (calibrated) / curve number (adjusted) / relative percent sensitivity } \\
\hline 21 & Developed, open space & +20 & $54 / 64.8 / 0.00$ & $70 / 84 /-0.20$ & $83 / 99.6 /-0.60$ & $83 / 99.6 /-0.10^{\mathrm{a}}$ & $76 / 91.2 /-0.10$ \\
\hline 21 & Developed, open space & -20 & $54 / 43.2 / 0.00$ & $70 / 56 / 0.00$ & $83 / 66.4 / 0.00$ & $83 / 66.4 / 0.00^{\mathrm{a}}$ & $76 / 60.8 / 0.00$ \\
\hline 41 & Deciduous forest & +20 & $38 / 45.6 / 0.00^{\mathrm{b}}$ & $55 / 66 /-0.30$ & $70 / 84 /-5.12$ & 77 / 92.4 / -2.71 & $63 / 75.6 /-0.40$ \\
\hline 41 & Deciduous forest & -20 & $38 / 30.4 / 0.00^{b}$ & $55 / 44 / 0.00$ & $70 / 56 / 1.00$ & 77 / 61.6 / 0.30 & $63 / 50.4 / 0.00$ \\
\hline 42 & Evergreen forest & +20 & $38 / 45.6 / 0.00^{b}$ & $60 / 72 /-0.10$ & $73 / 87.6 /-1.81$ & $79 / 94.8 /-0.60$ & $67 / 80.4 /-0.10$ \\
\hline 42 & Evergreen forest & -20 & $38 / 30.4 / 0.00^{b}$ & $60 / 48 / 0.00$ & $73 / 58.4 / 0.30$ & $79 / 63.2 / 0.00$ & $67 / 53.6 / 0.00$ \\
\hline 43 & Mixed forest & +20 & $38 / 45.6 / 0.00^{b}$ & $58 / 69.6 /-0.10$ & $72 / 86.4 /-1.71$ & $78 / 93.6 /-0.60$ & $65 / 78 /-0.10$ \\
\hline 43 & Mixed forest & -20 & $38 / 30.4 / 0.00^{b}$ & $58 / 46.4 / 0.00$ & $72 / 57.6 / 0.30$ & $78 / 62.4 / 0.00$ & $65 / 52 / 0.00$ \\
\hline 81 & Pasture/hay & +20 & $49 / 58.8 /-0.10$ & 69 / 82.8 / -1.91 & $79 / 94.8 /-6.53$ & $83 / 99.6 /-0.10^{\mathrm{a}}$ & $74 / 88.8 /-0.20$ \\
\hline 81 & Pasture/hay & -20 & 49 / 39.2 / 0.00 & 69 / 55.2 / 0.20 & $79 / 63.2 / 0.60$ & $83 / 66.4 / 0.00^{\mathrm{a}}$ & $74 / 59.2 / 0.00$ \\
\hline 82 & Cultivated crops & +20 & $67 / 80.4 /-1.81$ & 78 / $93.6 /-98.53$ & $83 / 99.6 /-49.34^{a}$ & $83 / 99.6 /-2.51^{a}$ & $82 / 98.4 /-0.70$ \\
\hline 82 & Cultivated crops & -20 & $67 / 53.6 / 0.20$ & 78 / 62.4 / 11.25 & 83 / 66.4 / 10.85 & $83 / 66.4 / 0.80^{\mathrm{a}}$ & $82 / 65.6 / 0.10$ \\
\hline 90 & Woody wetlands & +20 & $60 / 72 /-0.30$ & $60 / 72 /-0.30$ & $60 / 72 /-0.40$ & $60 / 72 /-0.10$ & $60 / 72 /-0.70$ \\
\hline 90 & Woody wetlands & -20 & $60 / 48 / 0.00$ & $60 / 48 / 0.00$ & $60 / 48 / 0.00$ & $60 / 48 / 0.00$ & $60 / 48 / 0.00$ \\
\hline 95 & Herbaceous wetlands & +20 & $60 / 72 /-0.10$ & $60 / 72 /-0.10$ & $60 / 72 /-0.10$ & $60 / 72 / 0.00$ & $60 / 72 /-0.20$ \\
\hline 95 & Herbaceous wetlands & -20 & $60 / 48 / 0.00$ & $60 / 48 / 0.00$ & $60 / 48 / 0.00$ & $60 / 48 / 0.00$ & $60 / 48 / 0.00$ \\
\hline
\end{tabular}


Table 10. Summary of relative percent sensitivity analysis from the base value in the lookup table of the calibrated Soil-Water-Balance (SWB) model. Each parameter was separately adjusted by plus or minus 20 percent to calculate the relative percent sensitivity.-Continued

[Bold text indcates lookup table parameters with greater than 2 percent relative percent sensitivity from the calibrated lookup table parameter]

\begin{tabular}{|c|c|c|c|c|c|c|c|}
\hline $\begin{array}{l}\text { Land-cover } \\
\text { class }\end{array}$ & Description & $\begin{array}{l}\text { Input, in percent change } \\
\text { from calibrated value }\end{array}$ & $\begin{array}{l}\text { Hydrologic } \\
\text { soil group A }\end{array}$ & $\begin{array}{l}\text { Hydrologic } \\
\text { soil group B }\end{array}$ & $\begin{array}{l}\text { Hydrologic } \\
\text { soil group C }\end{array}$ & $\begin{array}{l}\text { Hydrologic } \\
\text { soil group D }\end{array}$ & $\begin{array}{l}\text { Organic } \\
\text { soil group }\end{array}$ \\
\hline \multicolumn{8}{|c|}{ Root-zone, in feet (calibrated) / root-zone, in feet (adjusted) / relative percent sensitivity } \\
\hline 21 & Developed, open space & +20 & $2.66 / 3.192 /-0.10$ & $3.32 / 3.984 /-0.10$ & $2.12 / 2.544 /-0.10$ & $1.33 / 1.596 /-0.10$ & $2.72 / 3.264 /-0.10$ \\
\hline 21 & Developed, open space & -20 & $2.66 / 2.128 / 0.10$ & $3.32 / 2.656 / 0.10$ & $2.12 / 1.696 / 0.00$ & $1.33 / 1.064 / 0.00$ & $2.72 / 2.176 / 0.00$ \\
\hline 41 & Deciduous forest & +20 & $2.77 / 3.324 /-1.91$ & $2.31 / 2.772 /-2.61$ & $1.85 / 2.22 /-3.42$ & $1.62 / 1.944 /-0.50$ & $2.08 / 2.496 /-0.80$ \\
\hline 41 & Deciduous forest & -20 & $2.77 / 2.216 / 1.71$ & $2.31 / 1.848 / 3.11$ & 1.85 / 1.48 / 4.02 & $1.62 / 1.296 / 0.60$ & $2.08 / 1.664 / 1.00$ \\
\hline 42 & Evergreen forest & +20 & $3.16 / 3.792 /-0.30$ & $2.65 / 3.18 /-0.20$ & $2.12 / 2.544 /-0.60$ & $1.85 / 2.22 /-0.10$ & $2.39 / 2.868 /-0.10$ \\
\hline 42 & Evergreen forest & -20 & $3.16 / 2.528 / 0.20$ & $2.65 / 2.12 / 0.20$ & $2.12 / 1.696 / 0.60$ & $1.85 / 1.48 / 0.00$ & $2.39 / 1.912 / 0.00$ \\
\hline 43 & Mixed forest & +20 & $2.97 / 3.564 /-0.10$ & $2.48 / 2.976 /-0.10$ & $1.99 / 2.388 /-0.70$ & $1.74 / 2.088 /-0.10$ & $2.24 / 2.688 /-0.10$ \\
\hline 43 & Mixed forest & -20 & $2.97 / 2.376 / 0.00$ & $2.48 / 1.984 / 0.00$ & 1.99 / 1.592 / 0.80 & $1.74 / 1.392 / 0.10$ & $2.24 / 1.792 / 0.00$ \\
\hline 81 & Pasture/hay & +20 & $2.56 / 3.072 /-0.60$ & $3.2 / 3.84$ / - 1.51 & $2.56 / 3.072 /-1.21$ & $1.70 / 2.04 /-0.10$ & $2.87 / 3.444 /-0.10$ \\
\hline 81 & Pasture/hay & -20 & $2.56 / 2.048 / 0.60$ & $3.2 / 2.56 / 1.71$ & $2.56 / 2.048 / 1.41$ & $1.70 / 1.36 / 0.00$ & $2.87 / 2.296 / 0.10$ \\
\hline 82 & Cultivated crops & +20 & $2.12 / 2.544 /-2.61$ & $1.93 / 2.316 /-16.77$ & $1.89 / 2.268 /-6.63$ & $1.35 / 1.62 /-0.40$ & $1.91 / 2.292 /-0.10$ \\
\hline 82 & Cultivated crops & -20 & 2.12 / 1.696 / 3.21 & 1.93 / 1.544 / 20.99 & 1.89 / 1.512 / 8.74 & $1.35 / 1.08 / 0.40$ & $1.91 / 1.528 / 0.10$ \\
\hline 90 & Woody wetlands & +20 & $1.30 / 1.56 /-0.90$ & $1.44 / 1.728 /-0.70$ & $1.30 / 1.56 /-1.81$ & $1.14 / 1.368 /-0.20$ & $1.37 / 1.644 /-2.81$ \\
\hline 90 & Woody wetlands & -20 & $1.30 / 1.04 / 1.10$ & $1.44 / 1.152$ / 0.80 & $1.30 / 1.04 / 2.21$ & $1.14 / 0.912 / 0.10$ & 1.37 / $1.096 / 3.62$ \\
\hline 95 & Herbaceous wetlands & +20 & $1.58 / 1.896 /-0.40$ & $1.76 / 2.112 /-0.30$ & $1.58 / 1.896 /-0.30$ & $1.4 / 1.68 /-0.10$ & $1.67 / 2.004 /-0.70$ \\
\hline 95 & Herbaceous wetlands & -20 & $1.58 / 1.264$ / 0.40 & $1.76 / 1.408 / 0.30$ & $1.58 / 1.264$ / 0.20 & $1.4 / 1.12 / 0.00$ & $1.67 / 1.336 / 0.80$ \\
\hline
\end{tabular}

aBase value adjusted from calibrated value in table 3 to avoid an unrealistic curve number greater than 100 .

bBase value adjusted from calibrated value in table 3 to avoid an unrealistic curve number less than 30 . 
number models (Van Mullem, 1989). In these cases, the calibrated model was first re-run with a slightly different lookup parameter that would allow for the 20 percent increase and decrease in the curve number to fall within the practical range of 30 to 100 .

Only 21 combinations had a relative percent sensitivity that was $>2$ percent. Within this subset, the cultivated crops (land-cover class of 82) had the most sensitivity. In particular, changing the curve number for hydrologic soil groups B and $\mathrm{C}$ had the greatest effect on the overall potential recharge estimate from the SWB; increases in the curve number led to a recharge reduction, whereas a decrease in the curve number led to more infiltration and therefore more recharge. This is not unexpected given the geographical extent of the combination of land-cover class 82 with soil groups B and C, which together comprise 37.2 percent of the State. Increasing the runoff curve number from 78 to 93.6 for land-cover class 82 with soil group B caused nearly a 100 percent decrease in the overall potential recharge estimate. The only other major land cover with an appreciable number of relative percent sensitivities $>2$ percent was the deciduous forest group (land-cover class 41 ).

A sensitivity analysis also was completed by adjusting the meteorological parameters of precipitation, daily minimum air temperature, and daily maximum air temperature. This sensitivity analysis illustrates the effects of potential uncertainties in the input data on model results. Using the same methodology with relative percent sensitivity, table 11 shows the relative percent sensitivity with adjustments to meteorological parameters by 5,10 , and 20 percent.

Unlike lookup table adjustments, even 5-percent adjustments in the metrological parameters had a substantial effect on the final potential recharge estimate. Adjustments in the minimum temperature had the smallest effects, yet even a 5 -percent adjustment had a relative percent sensitivity of -25.61 percent. Increasing the minimum temperature by 20 percent had a relative percent sensitivity of 237.3 percent. Decreasing and increasing the maximum temperature had even greater effects on the relative percent sensitivity. In the cases of the minimum and maximum temperature, the high sensitivity is related to the effects on the ET, which will affect how much water moves to the root zone. To a smaller degree, changes in temperature would have an effect on whether precipitation fell as rain or snow. Precipitation also had substantial relative percent sensitivities, as precipitation shifts affect the overall amount of water available.

Overall, an evaluation of the relative percent sensitivity highlights the importance of using reliable climatological data. Small perturbations in these parameters had substantial effects on the final potential recharge estimates. For the lookup table, relative percent sensitivities generally were related to the overall geographical extent of the different land cover and hydrologic soil group combinations.
Table 11. Summary of relative percent sensitivity analysis for precipitation, daily minimum air temperature, and daily maximum air temperature from the base value used in the control file for the Soil-Water-Balance (SWB) model. Each parameter was adjusted by plus or minus 5,10 , and 20 percent, individually.

\begin{tabular}{ccc}
\hline $\begin{array}{c}\text { Control file } \\
\text { parameter }\end{array}$ & $\begin{array}{c}\text { Input, } \\
\text { in percent change } \\
\text { from calibrated value }\end{array}$ & $\begin{array}{c}\text { Relative percent } \\
\text { sensitivity }\end{array}$ \\
\hline Precipitation & +20 & 355.3 \\
& -20 & -278.4 \\
+10 & 170.9 \\
& -10 & -151.6 \\
& +5 & 83.37 \\
Minimum & -5 & -78.65 \\
temperature & +20 & 237.3 \\
& -20 & -61.97 \\
& +10 & 80.86 \\
& -10 & -43.19 \\
& +5 & 34.65 \\
& -5 & -25.61 \\
& +20 & -231.0 \\
& -20 & 702.8 \\
Maximum & +10 & -142.4 \\
& -10 & 247.9 \\
& +5 & -80.96 \\
& & 107.6 \\
\hline
\end{tabular}




\section{Summary}

Groundwater recharge is one of the most difficult components of a water budget to ascertain, yet is an important boundary condition necessary for the quantification of water resources. In Minnesota, improved estimates of recharge are necessary because approximately 75 percent of drinking water in Minnesota and 90 percent of agricultural irrigation water are supplied from groundwater. The water that is withdrawn must be supplied by some combination of (1) increased recharge, (2) decreased discharge to streams, lakes, and other surfacewater bodies, and (3) removal of water that was stored in the system. Recent pressure on groundwater resources has highlighted the need to provide more accurate recharge estimates for various tools that can assess the sustainability of long-term water use. As part of this effort, the U.S. Geological Survey, in cooperation with the Minnesota Pollution Control Agency, used the Soil-Water-Balance model to calculate mean gridded potential groundwater recharge estimates across Minnesota from 1996-2010 at a 1-kilometer (0.621-mile) resolution. The potential groundwater recharge estimates calculated for Minnesota from the Soil-Water Balance model included gridded values (1-kilometer resolution) of annual mean estimates (that is, the means for individual years from 1996 through 2010) and mean annual estimates (that is, the mean for the 15-year period 1996-2010).

The Soil-Water-Balance model uses a modified Thornthwaite-Mather soil-water-balance approach, with components of the soil-water balance calculated on a daily basis. A key advantage of this approach includes the use of commonly available geographic information system data layers that incorporate land cover, soil properties, and daily meteorological data to produce temporally and spatially variable gridded estimates of potential groundwater recharge. The Soil-WaterBalance model was calibrated by using a combination of parameter estimation techniques, making manual adjustments of model parameters, and using parameter values from previously published Soil-Water-Balance models. Each calibration simulation compared the potential recharge estimate from the model against base-flow estimates derived from three separate hydrograph separation techniques. A total of 35 Minnesota watersheds were selected for the model calibration.

Meteorological data necessary for the model included daily precipitation, minimum daily temperature, and maximum daily temperature. All of the meteorological data were provided by the Daymet dataset, which included daily continuous surfaces of key climatological data. Land-cover data were provided by the 2001 and 2006 National Land Cover Database: the 2001 classification was used from 1994 through 2003, and the 2006 classification was used from 2004 through 2010. Soil data used in the model included hydrologic soils group and the available soil-water capacity. These soil data were obtained from the Natural Resources Conservation Service Soil Survey Geographic (SSURGO) database and the State Soil Geographic (STATSGO) database.
The statewide mean annual potential recharge rate from 1996-2010 was 4.9 inches per year. Potential recharge estimates increased from west to east across Minnesota. The mean annual potential recharge estimates across Minnesota at a 1-kilometer resolution for the overall simulation period (1996-2010) ranged from less than 0.1 to 17.8 inches per year. Some of the lowest potential recharge rates for the simulation period were in the Red River of the North Basin of northwestern Minnesota, and generally were between 1.0 to 1.5 inches per year. The highest potential recharge rates were in northeastern Minnesota and the Anoka Sand Plain in central Minnesota. Eighty-eight percent of the potential recharge rates (by grid cell) were between 2 and 8 inches per year from 1996-2010. Only about 3 percent of all the potential recharge estimates (by grid cell) were less than 2 inches per year, and 9 percent of estimates were greater than 8 inches per year.

On an annual basis, however, potential recharge rates were as high as 27.2 inches per year. The highest annual mean recharge estimate across the State was for 2010, and the lowest mean recharge estimate was for 2003. Although precipitation variability partially explained the annual differences in potential recharge estimates, precipitation alone did not account for these differences, and other factors such as antecedent moisture conditions likely were important. Also, because differences in precipitation gradients across the State can vary from year to year, the dominant land-cover class and hydrologic soil group combinations had a strong effect on the resulting potential recharge value. During 1996-2010, April had the greatest monthly mean potential recharge compared to all other months, accounting for a mean of 30 percent of annual potential recharge in this single month.

\section{Acknowledgments}

The authors would like to thank David Lorenz of the U.S. Geological Survey with assistance for the Regional Regression Recharge model comparison. Geoff Delin and Jared Trost of the U.S. Geological Survey are acknowledged for their technical reviews of the report.

\section{References Cited}

Alley, W.M., 2006, Tracking U.S groundwater-Reserves for the future?: Environment: Science and Policy for Sustainable Development, v. 48, no. 6, p. 10-25. [Also available at http://dx.doi.org/10.3200/ENVT.48.3.10-25.]

Arnold, J.G., Muttiah, R.S., Srinivasan, R., and Allen, P.M., 2000, Regional estimation of baseflow and groundwater recharge in the Upper Mississippi river basin: Journal of Hydrology, v. 227, p. 21-40. [Also available at http://dx.doi. org/10.1016/S0022-1694(99)00139-0.] 
Aurand, K.A., 2013, Groundwater recharge estimates for the lower Tertiary and Upper Cretaceous aquifers in the Williston and Power River structural basins: Rapid City, South Dakota, South Dakota School of Mines and Technology, M.S. thesis, 107 p. [Also available at http://sd.water.usgs. gov/pubs/theses/Aurand_Thesis.pdf.]

Bredehoeft, John, 1997, Safe yield and the water budget myth: Ground Water, v. 35, no. 6, p. 929. [Also available at http:// dx.doi.org/10.1111/j.1745-6584.1997.tb00162.x.]

Cowdery, T.K., Lorenz, D.L., and Arntson, A.D., 2007, Hydrology prior to wetland and prairie restoration in and around the Glacial Ridge National Wildlife Refuge, northwestern Minnesota, 2005-5: U.S. Geological Survey Scientific Investigations Report 2007-5200, 74 p. [Also available at http://pubs.usgs.gov/sir/2007/5200/.]

Cronshey, R., McCuen, R., Miller, N., Rawls, W., Robbins, S., and Woodward, D., 1986, Urban hydrology for small watersheds-TR-55 (2nd ed.): Washington, D.C., U.S. Department of Agriculture, Soil Conservation Service, Engineering Division, Technical Release 55, 164 p. [Also available at http://www.nrcs.usda.gov/Internet/FSE_DOCUMENTS/ stelprdb1044171.pdf.]

Crosbie, R.S., Binning, Philip, and Kalma, J.D., 2005, A time series approach to inferring groundwater recharge using the water table fluctuation method: Water Resources Research, v. 41, no. 1, 9 p., W01008. [Also available at http://dx.doi. org/10.1029/2004WR003077.]

Delin, G.N., 1991, Hydrogeology and simulation of groundwater flow in the Rochester area, southeastern Minnesota, 1987-88: U.S. Geological Survey Water-Resources Investigations Report 90-4081, 108 p. [Also available at http:// pubs.er.usgs.gov/publication/wri904081.]

Delin, G.N., Healy, R.W., Landon, M.K., and Böhlke, J.K., 2000, Effects of topography and soil properties on recharge at two sites in an agricultural field: Journal of the American Water Resources Association, v. 36, no. 6, p. 1401-1416. [Also available at http://dx.doi. org/10.1111/j.1752-1688.2000.tb05735.x.]

Delin, G.N., Healy, R.W., Lorenz, D.L., and Nimmo, J.R., 2007, Comparison of local- to regional-scale estimates of ground-water recharge in Minnesota, USA: Journal of Hydrology, v. 334, no. 1-2, p. 231-249. [Also available at http://dx.doi.org/10.1016/j.jhydrol.2006.10.010.]

Doherty, John, 2010, PEST-Model-independent parameter estimation user manual (5th ed.): Brisbane, Australia, Watermark Numerical Computing, 336 p. [Also available at http://www.pesthomepage.org/getfiles.php?file=pestman. pdf.]
Donahue, R.L., Miller, R.W., and Shickluna, J.C., 1983, Soils-An introduction to soils and plant growth: Englewood Cliffs, New Jersey, Prentice Hall, p. 53.

Dripps, W.R., 2003, The spatial and temporal variability of groundwater recharge within the Trout Lake basin of northern Wisconsin: Madison, Wisconsin, University of Wisconsin, Ph.D. dissertation, $231 \mathrm{p}$.

Dripps, W.R., and Bradbury, K.R., 2007, A simple daily soilwater balance model for estimating the spatial and temporal distribution of groundwater recharge in temperate humid areas: Hydrogeology Journal, v. 15., no. 3, p. 433-444. [Also available at http://dx.doi.org/10.1007/s10040-0070160-6.]

Essaid, H.I., Cozzareilli, I.M., Eganhouse, R.P., Herkelrath, W.N., Bekins, B.A., and Delin, G.N., 2003, Inverse modeling of BTEX dissolution and biodegradation at the Bemidji, MN crude-oil spill site: Journal of Contaminant Hydrology, v. 67, no. 1-4, p. 263-299. [Also available at http://dx.doi. org/10.1016/S0169-7722(03)00034-2.]

Esri, 2012, ArcGIS 10.1 software: accessed November 14, 2014, at http://www.esri.com/.

Fry, J.A., Xian, G., Jin, S., Dewitz, J.A., Homer, C.G., Yang, L., Barnes, C.A., Herold, N.D., and Wickham, J.D., 2011, Completion of the 2006 National Land Cover Database for the Conterminous United States: Photogrammetric Engineering and Remote Sensing, v. 77, no. 9, p. 858-864. [Also available at http://www.mrlc.gov/downloadfile2. php?file=September2011PERS.pdf.]

Hargreaves, G.H., and Samani, Z.A., 1985, Reference crop evapotranspiration from temperature: Applied Engineering in Agriculture, v. 1, no. 2, p. 96-99. [Also available at http:// dx.doi.org/10.13031/2013.26773.]

Hart, D.J., Schoephoester, P.R., and Bradbury, K.R., 2008, Groundwater recharge in southeastern Wisconsin estimated by a GIS-based water-balance model: Madison, Wisconsin, University of Wisconsin-Extension, Wisconsin Geological and Natural History Survey, Technical Report 47, 31 p. [Also available at http://www.sewrpc.org/SEWRPCFiles/ Publications/TechRep/tr-047_groundwater_recharge.pdf.]

Hart, D.J., Schoephoester, P.R., and Bradbury, K.R., 2009, Groundwater recharge in Dane County, Wisconsin, estimated by a GIS-based water-balance model: Madison, Wisconsin, University of Wisconsin-Extension, Wisconsin Geological and Natural History Survey, Open-File Report 2009-01, 16 p. [Also available at http://wgnhs.uwex.edu/ pubs/000130/.] 
Hart, D.J., and Schoephoester, P.R., 2011, Groundwater recharge in Calumet, Outagamie, and Winnebago Counties, Wisconsin, estimated by a GIS-based water-balance model: Madison, Wisconsin, University of Wisconsin-Extension, Wisconsin Geological and Natural History Survey, OpenFile Report 2011-05, 26 p. [Also available at http://wgnhs. uwex.edu/pubs/wofr201105/.]

Hart, D.J., and Schoephoester, P.R., 2014, Groundwater recharge in Menominee, Shawano, Waupaca, and Waushara Counties, Wisconsin, estimated by a GIS-based waterbalance model: Madison, Wisconsin, University of Wisconsin-Extension, Wisconsin Geological and Natural History Survey, Open-File Report 2014-02, 24 p. [Also available at http://wgnhs.uwex.edu/pubs/wofr201402/.]

Healy, R.W., and Cook, P.G., 2002, Using groundwater levels to estimate recharge: Hydrogeology Journal, v. 10, p. 91-109. [Also available at http://dx.doi.org/10.1007/ s10040-001-0178-0.]

Healy, R.W., and Scanlon, B.R., 2010, Estimating groundwater recharge: New York, N.Y., Cambridge University Press, $256 \mathrm{p}$.

Hjelmfelt, A.T., Jr., 1991, Investigation of curve number procedure: Journal of Hydraulic Engineering, v. 117, no. 6, p. 725-737. [Also available at http://dx.doi.org/10.1061/ (ASCE)0733-9429(1991)117:6(725).]

Homer, C., Dewitz, J., Fry, J., Coan, M., Hossain, N., Larson, C., Herold, N., McKerrow, A., VanDriel, J.N., and Wickham, J., 2007, Completion of the 2001 National Land Cover Database for the Conterminous United States: Photogrammetric Engineering and Remote Sensing, v. 73, no. 4, p. 337-341. [Also available at http://www.asprs.org/a/publications/pers/2007journal/april/highlight.pdf.]

Jyrkama, M.I., Sykes, J.F., and Normani, S.D., 2002, Recharge estimation for transient ground water modeling: Ground Water, v. 40, no. 6, p. 237-250. [Also available at http:// dx.doi.org/10.1111/j.1745-6584.2002.tb02550.x.]

Kanivetsky, R., 1979, Regional approach to estimating the ground-water resources of Minnesota: St. Paul, Minn., University of Minnesota, Minnesota Geological Survey, Report of Investigations 22, 24 p. [Also available at http:// purl.umn.edu/60457.]

Legates, D.R., and McCabe, G.J., Jr., 1999, Evaluating the use of "goodness-of-fit" measures in hydrologic and hydroclimatic model validation: Water Resources Research, v. 35, no. 1, p. 233-241. [Also available at http://dx.doi. org/10.1029/1998WR900018.]
Lindgren, R.J., 1996, Availability and quality of water from drift aquifer in Marshall, Pennington, Polk, and Red Lake Counties, northwestern Minnesota: U.S. Geological Survey Water-Resources Investigations Report 95-4201, 154 p. [Also available at http://pubs.er.usgs.gov/publication/ wri954201.]

Lindgren, R.J., 2001, Effects of ground-water withdrawals on flow in the Sauk River Valley aquifer and on streamflow in the Cold Spring area, Minnesota: U.S. Geological Survey Water-Resources Investigations Report 01-4111, 42 p. [Also available at http://mn.water.usgs.gov/publications/ pubs/01-4111.pdf.]

Lindgren, R.J., and Landon, M.K., 2000, Effects of groundwater withdrawals on the Rock River and associated valley aquifer, eastern Rock County, Minnesota: U.S. Geological Survey Water-Resources Investigations Report 99-4157, 114 p. [Also available at http://pubs.er.usgs.gov/publication/ wri994157.]

Lindholm, G.F., 1980, Ground-water appraisal of sand plains in Benton, Sherburne, Stearns, and Wright Counties, central Minnesota: U.S. Geological Survey Water-Resources Investigations Open-File Report 80-1285, 111 p. [Also available at http://pubs.usgs.gov/of/1980/1285/report.pdf.]

Lorenz, D.L., and Delin, G.N., 2007, A regression model to estimate regional ground water recharge: Ground Water, v. 45, no. 2, p. 196-208. [Also available at http://dx.doi. org/10.1111/j.1745-6584.2006.00273.x.]

Masterson, J.P., Pope, J.P., Monti, Jack, Jr., Nardi, M.R., Finkelstein, J.S., and McCoy, K.J., 2013, Hydrogeology and hydrologic conditions of the Northern Atlantic Coastal Plain Aquifer System from Long Island, New York, to North Carolina: U.S. Geological Survey Scientific Investigations Report 2013-5133, 76 p. [Also available at http://dx.doi. org/10.3133/sir20135133.]

McMahon, P.B., Plummer, L.N., Böhlke, J.K., Shapiro, S.D., and Hinkle, S.R., 2011, A comparison of recharge rates in aquifers of the United States based on groundwater-age data: Hydrogeology Journal, v. 19, no. 4, p. 779-800. [Also available at http://dx.doi.org/10.1007/s10040-011-0722-5.]

Metropolitan Council, 2013, Using a soil water balance (SWB) model to estimate recharge for version 3 of the Twin Cities Metropolitan Area groundwater model: St. Paul, Metropolitan Council, 65 p.

Minnesota Department of Natural Resources, 1993, Regional hydrogeologic assessment-Anoka Sand Plain, Minnesota: accessed December 31, 2014, at http://www.dnr.state.mn.us/ waters/programs/gw_section/mapping/platesum/asprha. html. 
Minnesota Department of Natural Resources, 2007, Regional groundwater recharge estimates for Minnesota: accessed August 26, 2014, at http://www.dnr.state.mn.us/groundwater/groundwater_recharge_metadata.html.

Minnesota Department of Natural Resources, 2014, Groundwater information: accessed August 26, 2014, at http:// www.dnr.state.mn.us/groundwater/index.html.

Myette, C.F., 1986, Hydrogeology of sand-plain aquifers in Carlton, Kanabec, and Pine Counties, east central Minnesota: U.S. Geological Survey Water-Resources Investigations Report 85-4334, 72 p. [Also available at http://pubs. er.usgs.gov/publication/wri854334.]

Nash, J.E, and Sutcliffe, I.V., 1970, River flow forecasting through conceptual models, Part 1-A discussion of principles: Journal of Hydrology, v. 10, no. 3, p. 282-290. [Also available at http://dx.doi.org/10.1016/0022-1694(70)902556$.

Natural Resources Conservation Service, 2005, Soil survey geographic (SSURGO) data base-Data use information: Fort Worth, Texas, U.S. Department of Agriculture, Natural Resources Conservation Service, Miscellaneous Publication Number 1527,110 p.

Natural Resources Conservation Service, 2008, Available water capacity: Fort Worth, Texas, U.S. Department of Agriculture, Natural Resources Conservation Service, Soil Quality Indicators Series, 2 p. [Also available at http://www.nrcs. usda.gov/wps/PA_NRCSConsumption/download?cid=nres1 42p2_051590\&ext=pdf.]

Natural Resources Conservation Service, 2014, Web soil survey: U.S. Department of Agriculture, Natural Resources Conservation Service, accessed August 26, 2014, at http:// websoilsurvey.nrcs.usda.gov/app/WebSoilSurvey.aspx.

Neff, B.P., Piggott, A.R., and Sheets, R.,A., 2006, Estimation of shallow ground-water-recharge in the Great Lakes Basin: U.S. Geological Survey Scientific Investigations Report 2005-5284, 31 p. [Also available at http://pubs.usgs.gov/ $\operatorname{sir} / 2005 / 5284 /$.

Nimmo, J.R., Stonestrom, D.A., and Akstin, K.C., 1994, The feasibility of recharge rate measurements using the steady state centrifuge method: Soil Science Society of America Journal, v. 58, p. 49-56. [Also available at http://dx.doi. org/10.2136/sssaj1994.03615995005800010007x.]

Ponce, V.M., and Hawkins, R.H., 1996, Runoff curve numbers-Has it reached maturity?: Journal of Hydrologic Engineering, v. 1, no. 1, p. 11-19. [Also available at http:// dx.doi.org/10.1061/(ASCE)1084-0699(1996)1:1(11).]
Ruhl, J.F., Kanivetsky, R., and Shmagin, B., 2002, Estimates of recharge to unconfined aquifers and leakage to confined aquifers in the seven-county metropolitan area of Minneapolis-St. Paul, Minnesota: U. S. Geological Survey Water-Resources Investigations Report 02-4092, 38 p. [Also available at http://pubs.er.usgs.gov/publication/ wri20024092.]

Rutledge, A.T., 1998, Computer programs for describing the recession of ground-water discharge and for estimating mean ground-water recharge and discharge from streamflow records-Update: U.S. Geological Survey Water-Resources Investigations Report 98-4148, 52 p. [Also available at http://pubs.usgs.gov/wri/wri984148/pdf/wri98-4148.pdf.]

Scanlon, B.R., Healy, R.W., and Cook, P.G., 2002, Choosing appropriate techniques for quantifying groundwater recharge: Hydrogeology Journal, v. 10, no. 1, p. 18-39. [Also available at http://dx.doi.org/10.1007/s10040-0010176-2.]

Schoenberg, M.E., 1998, Hydrogeology and sources of recharge to the Buffalo and Wahpeton Aquifers in the southern part of the Red River of the North drainage basin, west-central Minnesota and southeastern North Dakota: U.S. Geological Survey Water-Resources Investigations Report 97-4084, 40 p. [Also available at http://pubs.er.usgs. gov/publication/wri974084.]

Sloto, R.A., and Crouse, M.Y., 1996, HYSEP-A computer program for streamflow hydrograph separation and analysis: U.S. Geological Survey Water-Resources Investigations Report 96-4040, 54 p. [Also available at http://water.usgs. gov/software/HYSEP/code/doc/hysep.pdf.]

Soukup, W.G., Gillies, D.C., and Myette, C.F., 1984, Appraisal of the surficial aquifers in the Pomme de Terre and Chippewa River valleys: U.S. Geological Survey WaterResources Investigations Report 84-4086, 69 p. [Also available at http://pubs.usgs.gov/wri/1984/4086/report.pdf.]

Stanton, J.S., Qi, S.L., Ryter, D.W., Falk, S.E., Houston, N.A., Peterson, S.M., Westenbroek, S.M., and Christenson, S.C., 2011, Selected approaches to estimate water-budget components of the High Plains, 1940 through 1949 and 2000 through 2009: U.S. Geological Survey Scientific Investigations Report 2011-5183, 79 p. [Also available at http://pubs. usgs.gov/sir/2011/5183/.]

Stark, J.R., Busch, J.P., and Deters, M.H., 1991, Hydrogeology and water quality of glacial-drift aquifers in the BemidjiBagley area, Beltrami, Clearwater, Cass, and Hubbard Counties, Minnesota: U.S. Geological Survey WaterResources Investigations Report 89-4136, 145 p. [Also available at http://pubs.usgs.gov/wri/1989/4136/report.pdf.] 
Thornthwaite, C.W., 1948, An approach towards a rational classification of climate: Geographical Review, v. 38, no. 1, p. 55-94. [Also available at http://dx.doi. org/10.2307/210739.]

Thornthwaite, C.W., and Mather, J.R., 1955, The water balance: Centeron, New Jersey, Laboratory of Climatology, Publications in Climatology, v. 8, no. 1, p. 1-104.

Thornthwaite, C.W. and Mather, J.R., 1957, Instructions and tables for computing potential evapotranspiration and the water balance: Centerton, New Jersey, Laboratory of Climatology, Publications in Climatology, v. 10, no. 3, p. 185-311.

Thornton, P.E., Running, S.W., and White, M.A. 1997, Generating surfaces of daily meteorological variables over large regions of complex terrain: Journal of Hydrology, v. 190, no. 3-4, p. 214-251. [Also available at http://dx.doi. org/10.1016/S0022-1694(96)03128-9.]

Thornton, P.E., Thornton, M.M., Mayer, B.W., Wilhelmi, N., Wei, Y., and Cook, R.B., 2012, Daymet-Daily surface weather on a 1-km grid for North America, 1980-2012: accessed September 30, 2014, at http://daac.ornl.gov/cgibin/dsviewer.pl?ds_id=1219.

U.S. Geological Survey, 2015, U.S. Geological Survey National Water Information System, water data for Minnesota-Web interface: accessed March 26, 2015, at http:// waterdata.usgs.gov/mn/nwis/nwis.

Vaccaro, J.J., 2007, A deep percolation model for estimating ground-water recharge-Documentation of modules for the modular modeling system of the U.S. Geological Survey: U.S. Geological Survey Scientific Investigations Report 2006-5318, 30 p. [Also available at http://pubs.usgs.gov/ sir/2006/5318/pdf/sir20065318.pdf.)

Van Mullem, J.A., 1989, Runoff and peak discharges using Green-Ampt infiltration model: Journal of Hydraulic Engineering, v. 117, no. 3, p. 354-370. [Also available at http:// dx.doi.org/10.1061/(ASCE)0733-9429(1991)117:3(354).]

Veihmeyer, F.J., and Hendrickson, A.H., 1931, The moisture equivalent as a measure of the field-capacity of soils: Soil Science, v. 32, no. 3, p. 181-194.
Wahl, T.L., and Wahl, K.L., 2014, BFI: A computer program for determining an index to base flow: accessed October 4, 2014, at http://www.usbr.gov/pmts/hydraulics_lab/twahl/ bfi/.

Wehmeyer, L.L., Weirich, F.H., and Cuffney, T.F., 2011, Effect of land cover change on runoff curve number estimation in Iowa, 1832-2001: Ecohydrology, v. 4, no. 2, p. 315-321. [Also available at http://dx.doi.org/10.1002/eco.162.]

Westenbroek, S.M., Kelson, V.A., Dripps, W.R., Hunt, R.J., and Bradbury, K.R., 2010, SWB-A modified Thornthwaite-Mather Soil-Water-Balance code for estimating groundwater recharge: U.S. Geological Survey Techniques and Methods, book 6, chap. A31, 60 p. [Also available at http://pubs.usgs.gov/tm/tm6-a31/.]

Westenbroek, S.M., Doherty, J., Walker, J.F., Kelson, V.A., Hunt, R.J., and Cera, T.B., 2012, Approaches in highly parameterized inversion-TSPROC, a general time-series processor to assist in model calibration and result summarization: U.S. Geological Survey Techniques and Methods, book 7, chap. C7, 79 p. [Also available at http://pubs.usgs. gov/tm/tm $7 \mathrm{c} 7 /$.

Wolock, D.M., 2003a, Base-flow index grid for the conterminous United States: U.S. Geological Survey Open-File Report 2003-263, digital data set. [Also available at http:// ks.water.usgs.gov/pubs/abstracts/of.03-263.htm.]

Woodward, D.E., Hawkins, R.H., Jiang, R., Hjelmfelt, A.T., Van Mullem, J.A., and Quan, Q.D., 2003, Runoff curve number method-Examination of the initial abstraction ratio, in World Water and Environmental Congress 2003, Conference Proceedings Paper, June 24-26, Philadelphia: American Society of Civil Engineers, 12 p.

Wolock, D.M., 2003b, Flow characteristics at U.S. Geological Survey streamgages in the conterminous United States: U.S. Geological Survey Open-File Report 2003-146, digital data set. [Also available at http://water.usgs.gov/GIS/metadata/usgswrd/XML/qsitesdd.xml.]

Zhou, Yangxiao, 2009, A critical review of groundwater budget myth, safe yield and sustainability: Journal of Hydrology, v. 370, no. 1-4, p. 207-213. [Also available at http:// dx.doi.org/10.1016/j.jhydrol.2009.03.009.] 
Appendixes 


\section{Appendix 1. Control File for the Minnesota Soil-Water-Balance Model}

This appendix presents the control file for the Minnesota Soil-Water-Balance (SWB) model to estimate potential recharge. This control file works with the SWB executable module, compiled on October 4, 2014. Any changes to the SWB executable module with newer versions might have modifications that would require adaptations to the following control file.

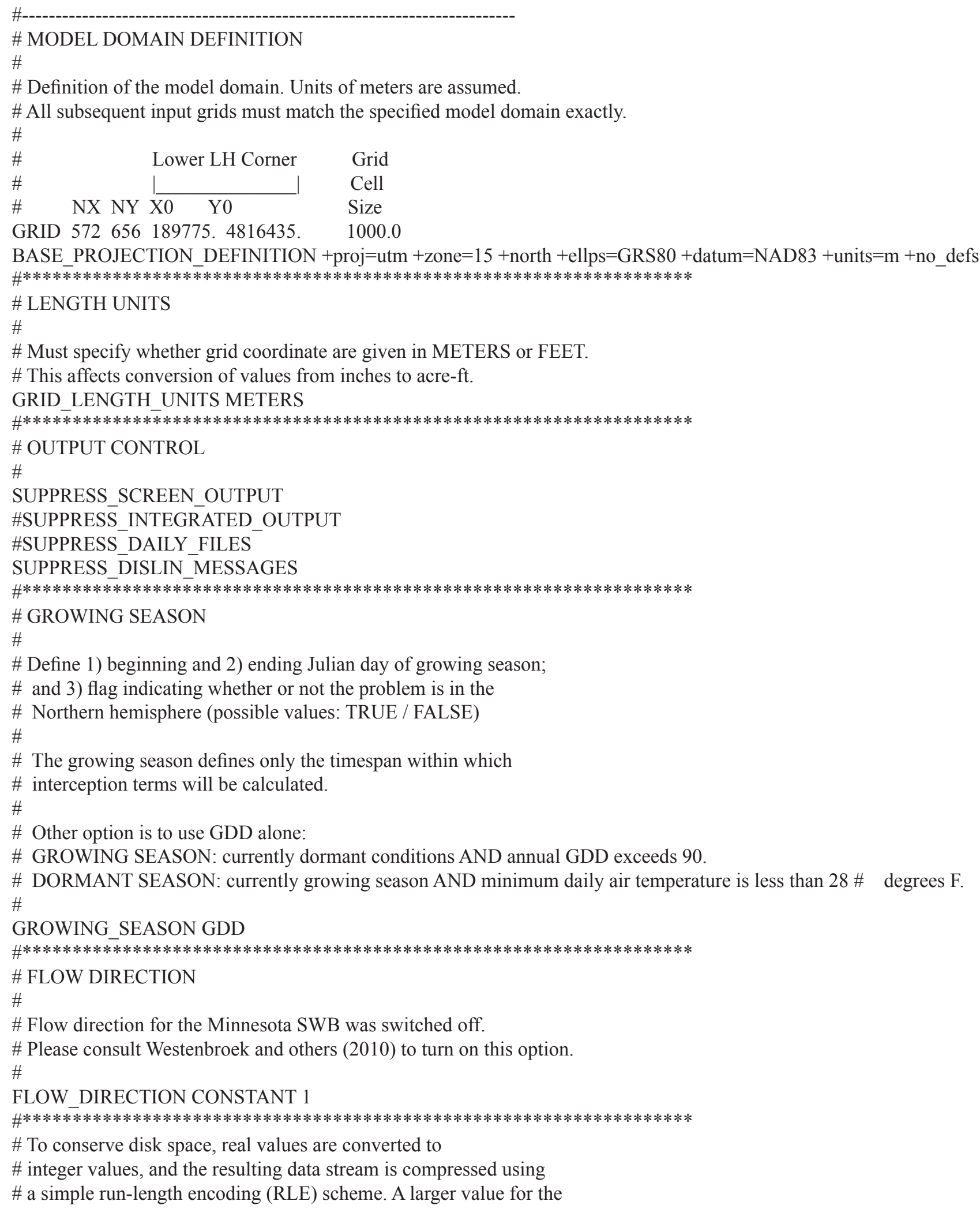


\# RLE multiplier preserves more of the real data value and lowers the \# amount of data compression that takes place.

\#

RLE MULTIPLIER 10000

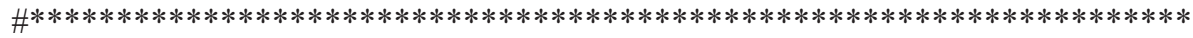

\# PRECIPITATION

\#

\# Daymet climatological data were used for the Minnesota SWB model.

\# All Daymet was stored locally to run. Simulations can be run

\# "on-the-fly" by running against online Daymet climatological data;

\# however, this functionality was not pursued due to speed constraints.

\# All Daymet data are stored in millimeters, so SWB needs to convert to

\# inches; hence, the conversion factor.

\#

PRECIPITATION NETCDF ..Idaymet1\%Y-\%0\#_prcp.nc

PRECIPITATION_GRID_PROJECTION_DEFINITION + proj $=1 \mathrm{cc}+$ lat_ $1=25.0+$ lat_2 $=60.0+$ lat_ $0=42.5+$ lon_0 $=-100.0$

$+\mathrm{x} \_0=0.0+\mathrm{y} \_0=0.0+$ ellps $=$ GRS $80+$ datum $=\mathrm{NAD} 83+$ units $=\mathrm{m}+$ no $\_$def

PRECIPITATION_CONVERSION_FACTOR 0.03936996

PRECIPITATION_MISSING_VALÜES_CODE -32768

PRECIPITATION_MISSING_VALUES_OPERATOR $<=$

PRECIPITATION_MISSING_VALUES_ACTION ZERO

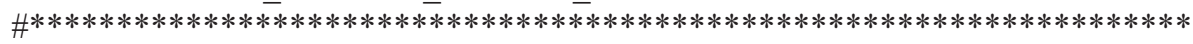

\# TEMPERATURE

\#

\# All Daymet data are stored in Celsius, so SWB needs to convert to

\# Fahrenheit; hence, the conversion factor and offset.

\#

TEMPERATURE NETCDF ..Idaymet \%\%-\%0\#_tmax.nc ... daymet $\%$ Y-\%0\#_tmin.nc

TMAX_GRID_PROJECTION_DEFINITION + proj $=1 \mathrm{lcc}+$ lat_ $1=25.0+$ lat_ $2=60.0+$ lat $0=42.5+$ lon_ $0=-100.0+\mathrm{x} \_0=0.0$ $+\mathrm{y} \_0=0.0+$ ellps $=$ GRS $80+$ datum $=$ NAD $83+$ units $=\mathrm{m}+$ no_defs

TMAX_MISSING_VALUES_CODE - 128

TMAX_MISSING_VALUES_OPERATOR $<=$

TMAX_MISSING_VALUES_ACTION MEAN

TMAX_SCALE_FACTOR 1.8

TMAX_ADD_OFFSET 32

TMIN_GRID_PROJECTION_DEFINITION + proj $=1 \mathrm{lcc}+$ lat_ $1=25.0+$ lat_ $2=60.0+$ lat_ $0=42.5+$ lon_ $0=-100.0+\mathrm{x} \_0=0.0$

$+\mathrm{y} \_0=0.0+$ ellps $=$ GRS $80+$ datum $=$ NAD $83+$ units $=\mathrm{m}+$ no_defs

TMIN_MISSING_VALUES_CODE -128

TMIN_MISSING_VALUES_OPERATOR $<=$

TMIN_MISSING_VALUES_ACTION MEAN

TMIN_SCALE_FACTOR $1 . \overline{8}$

TMIN_ADD_OFFSET 32

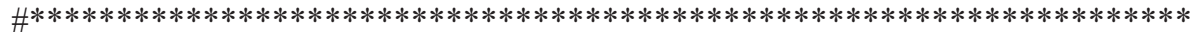

\# OUTPUT GRID FILENAME SUFFIX

\#

\# Set the output grid filename suffix with the OUTPUT_GRID_SUFFIX

\# option. This applies only to annual and monthly output grids.

\# Daily grids have the filename pattern filename.\#\#, where \#\#\#

\# is the Julian day of the simulation

\#

OUTPUT_GRID_SUFFIX asc

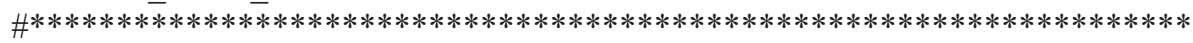

\# INITIAL ABSTRACTION METHOD

\#

\# The method for calculating the initial abstraction within the

\# Runoff curve number procedure may be specified in two ways: 
\#

\# 1) TR-55: Ia is assumed equal to $0.2 * \mathrm{~S}$

\# 2) Woodward and others (2003): Ia is assumed equal to $0.05 * \mathrm{~S}$

\#

\# If the Hawkins method is used, curve numbers are adjusted

\# as per Equation 9 of Woodward and others (2003). Net effect should be to

\# increase runoff for smaller precip events. This method has been

\# suggested to be more appropriate to long-term simulation model applications.

\#

INITIAL ABSTRACTION METHOD TR55

$\# * * * * * * * * * * * * * * * * * * * * * \pi * * * * * * * * * * * * * * * * * * * * * * * * * * * * * * * * * * * * * * * * * * * * *$

\# INITIAL CONTINUOUS FROZEN GROUND INDEX

\#

\# assume that ground is initially frozen, "frozen" $>=83$

\#

INITIAL FROZEN GROUND INDEX CONSTANT 100.0

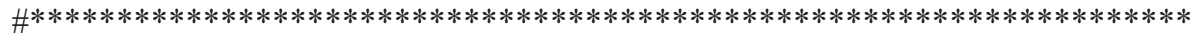

\# FROZEN GROUND THRESHOLD CFGI VALUE

\#

\# Use this option to set a different value defining the boundary

\# between "unfrozen" and "frozen" ground. Literature value is 83 .

\# For example, for a CFGI $<83$, the ground is considered unfrozen;

\# with a CFGI $>=83$, the ground is considered frozen.

\#

\# When frozen ground conditions exist, the curve numbers are uniformly

\# assumed to reflect antecedent runoff condition III (i.e. increased

\# proportion of runoff for a given amount of precipitation).

\#

\#

UPPER_LIMIT_CFGI 83.

LOWER_LIMIT_CFGI 55.

$\# * * * * * * * * * * * * * * * * * * * * * * * * * * * * * * * * * * * * * * * * * * * * * * * * * * * * * * * * * * * * * * * * * * * *$

\# ADDITIONAL CONTROL FACTORS FOR RAINFALL/SNOWFALL CORRECTIONS

\#

\# Input meteorological data can be modified by altering the

\# conversion and scale factors above. These additional controls

\# allow for user-intervention on how to alter rainfall, snowfall,

\# or both. In the Minnesota SWB, no alteration was used and these

\# values were left as 1.

\#

RAINFALL_CORRECTION_FACTOR 1.00

SNOWFALL_CORRECTION_FACTOR 1.00

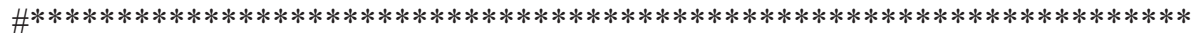

\# REFERENCE EVAPOTRANSPIRATION

\#

REFERENCE_ET_SLOPE 2.3000000E-03

REFERENCE_ET_EXPONENT $5.0000000 \mathrm{E}-01$

REFERENCE_ET_CONSTANT $1.7800000 \mathrm{E}+01$

$\# * * * * * * * * * * * * * * * * * * * * * * * * * * * * * * * * * * * * * * * * * * * * * * * * * * * * * * * * * * * * * * * * * * *$

\# SOIL GROUP

$\#$

\# Curve Number Hydrologic Soil Groups: The Soil Conservation Service (SCS)

\# has categorized every soil within the United States into one of four

\# hydrologic soil groups based on its infiltration capacity (A - D)

\# (input to the model as 1 - 4).

\# "A" soils have a high minimum infiltration capacity and subsequently a low 
\# overland flow potential, whereas " $\mathrm{D}$ " soils have a very low infiltration

\# capacity and subsequently a high overland flow potential.

\# For further information on designation of hydrologic soil groups in Minnesota,

\# consult the section on "Hydrologic soil groups"

\#

SOIL_GROUP ARC_GRID input|soils_hyd_grp.asc

SOIL_GROUP_PROJECTION_DEFINITION + proj $=$ utm +zone $=15+$ north + ellps $=$ GRS $80+$ datum $=$ NAD $83+$ units $=\mathrm{m}$ + no defs

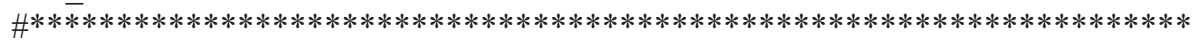

\# LAND USE/COVER CLASSIFICATION

\#

\# The model uses land use information, together with

\# the soil available water capacity information, to calculate surface

\# runoff and assign a maximum soil moisture holding capacity for each

\# grid cell.

\# By designating as DYNAMIC, multiple classifications may be used.

\# In the Minnesota SWB model,

\#

LAND_USE DYNAMIC ARC_GRID input|NLCD_\%Yasc

LANDUSE_PROJECTION_DEFINITION + proj=utm + zone $=15+$ north + ellps $=$ GRS $80+$ datum $=$ NAD $83+$ units $=$ m + no_defs

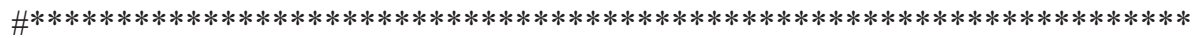

\# SPECIFY OPEN WATER LAND USE

\#

\# This option forces the cells of the given land use to be treated

\# as open water cells. In these cells, recharge is *NOT* calculated,

\# nor is flow routing or soil-moisture accounting done. Water is

\# either allowed to leave these cells as actual ET, or assumed to leave

\# the grid flow out of grid via surface water features.

\#

OPEN_WATER_LAND_USE 11

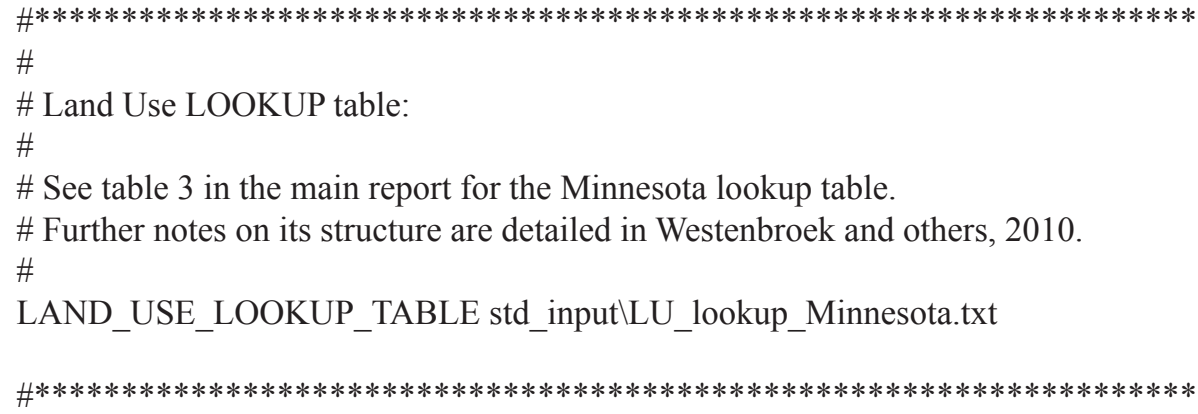


\# The Thornthwaite-Mather soil moisture retention tables are included

\# in the standard table "soil-moisture-retention-extended.grd"

\#

SM T-M EQUATIONS

$\# * * * * * * * * * * * * * * * * * * * * * * * * * * * * * * * * * * * * * * * * * * * * * * * * * * * * * * * * * * * * * * * * * * * *$

\# INITIAL SOIL MOISTURE

\#

\# If CONSTANT, initial soil moisture is specified as a PERCENTAGE saturation

\# of the available water capacity.

\#

\# If an ASCII GRID FILE, initial soil moisture is specified in INCHES of water.

\# An ASCII grid file from a 1994 simulation

\# was used for initializing the model period 1995-2011. This earlier

\# control file would appear the same, with the exception that this

\# option would be used for soil moisture:

\# INITIAL_SOIL_MOISTURE CONSTANT 100

INITIAL_SOIL_MOISTURE ARC_GRID output futurelswb_future_final_pct_sm_1994.asc

$\# * * * * * * * * * * * * * * * * * * * * * * * * * * * * * * * * * * * * * * * * * * * * * * * * * * * * * * * * * * * * * * * * * * *)$

\# INITIAL SNOW COVER

\#

\# Initial snow cover is specified as an equivalent moisture value.

\# This may be specified as a single constant value

\# or as an ASCII grid file. An ASCII grid file from a 1994 simulation

\# was used for initializing the model period 1996-2010. This earlier

\# control file would appear the same, with the exception that this

\# option would be used for snow cover:

\# INITIAL_SNOW_COVER CONSTANT 0

\#

INITIAL_SNOW_COVERARC_GRID output|futurelswb_future_final_snow_cover_1994.asc $\# * * * * * * \pi * * * * * * \bar{*} * * * * * * * * * * * \pi * * * * * * * * * * * * * * * * * * * * \bar{*} * * * * * \bar{*} * * * \bar{*} * * * * \pi * * * * * \overline{1}$

\# SOLUTION METHOD

\#

\# Three solution methods are available for the routing of surface water

\# through the model domain. The "ITERATIVE" method, the "DOWNHILL" method,

\# and "NO ROUTING". The "NO ROUTING" option was used for the Minnesota

\# SWB model.

\#

RUNOFF C-N NO ROUTING

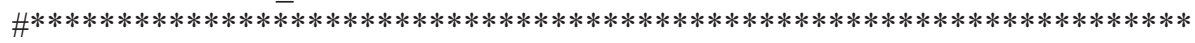

\# EVAPOTRANSPIRATION METHOD

\#

\# Hargreaves (program option: "HARGREAVES" southerly lat northerly lat)

\#

ET HARGREAVES 43.549 .38

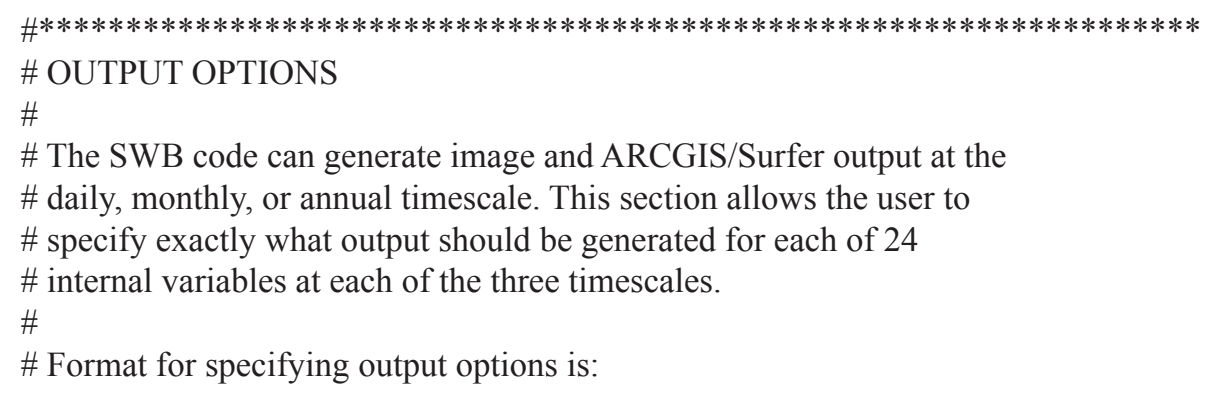




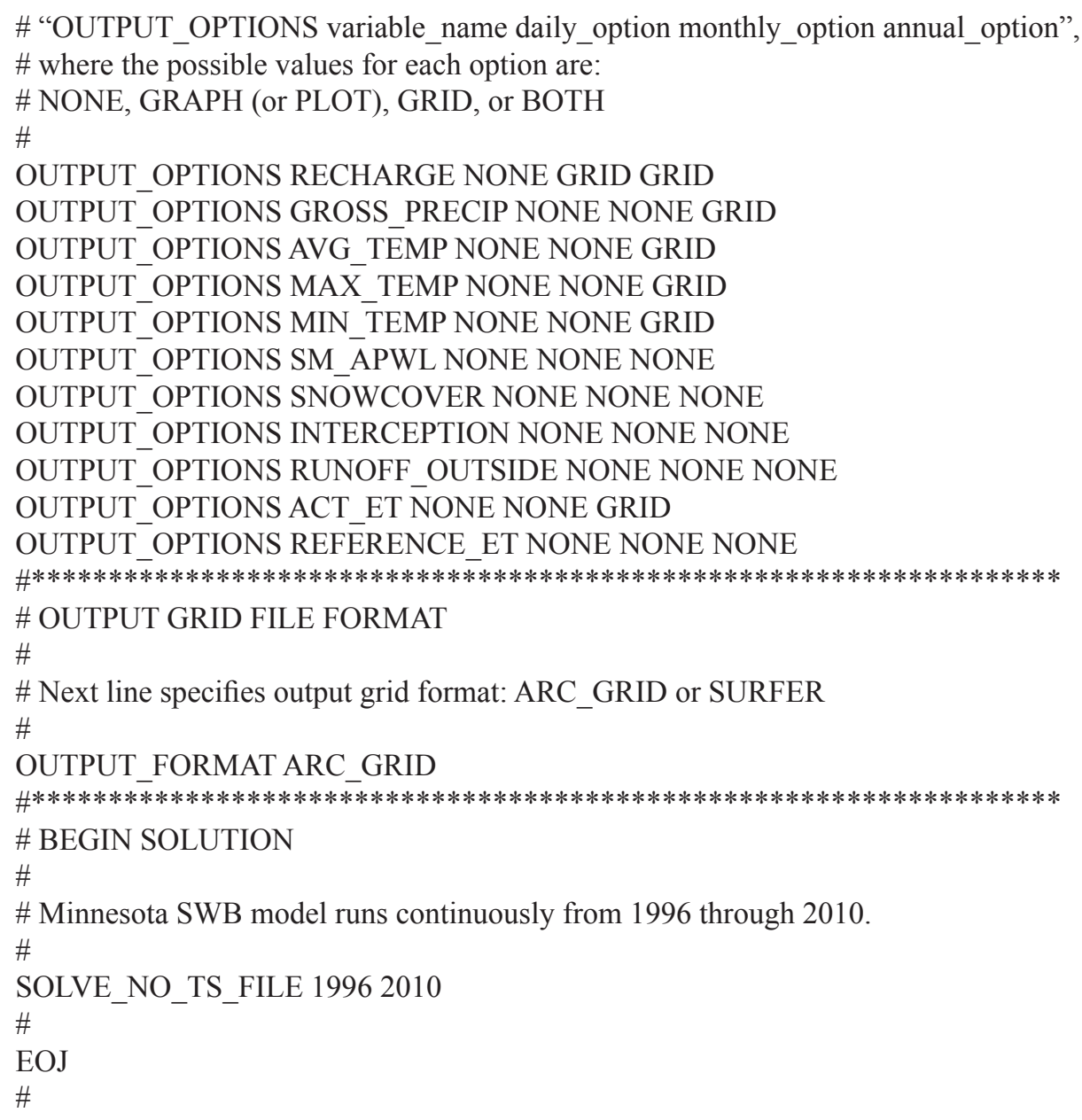




\section{Appendix 2. Model Calibration Analysis}

Base-flow estimates for individual years from 1996 through 2010 for the 35 reference watersheds used in model calibration analysis with annual recharge rates during the period analyzed by using PART, HYSEP fixed-interval method, and HYSEP sliding method in comparison to the estimated potential recharge rates for the same year from the Soil-Water-Balance (SWB) model are included in table 2-1. The relative error is the SWB potential recharge estimate to the mean of the three different base-flow estimates. 
Table 2-1. Annual mean base-flow estimates rates from 1996-2010 using three hydrograph separation techniques for the 35 streamgages used in model calibration analysis in comparison to the estimated annual potential recharge rates for the same period from the Soil-Water-Balance (SWB) model.

[USGS, U.S. Geological Survey; in/yr, inches per year; Minn., Minnesota; NA, not applicable]

\begin{tabular}{|c|c|c|c|c|c|c|c|}
\hline \multirow[b]{2}{*}{ USGS streamgage name or statistic } & \multirow{2}{*}{$\begin{array}{c}\text { USGS } \\
\text { streamgage } \\
\text { number }\end{array}$} & \multirow[b]{2}{*}{ Year } & \multicolumn{3}{|c|}{ Base-flow estimate (in/yr) } & \multirow{2}{*}{$\begin{array}{c}\text { Potential recharge rate } \\
\text { from SWB model } \\
\text { (in/yr) }\end{array}$} & \multirow[b]{2}{*}{ Relative error ${ }^{c}$} \\
\hline & & & $\begin{array}{l}\text { PART }^{a} \\
\text { (in/yr) }\end{array}$ & $\begin{array}{l}\text { HYSEP fixed- } \\
\text { interval method }\end{array}$ & $\begin{array}{l}\text { HYSEP sliding } \\
\text { method }^{b}\end{array}$ & & \\
\hline Knife River near Two Harbors, Minn. & 04015330 & 1996 & 10.46 & 9.87 & 10.08 & 10.27 & 0.01 \\
\hline Knife River near Two Harbors, Minn. & 04015330 & 1997 & 8.87 & 8.45 & 8.72 & 8.81 & 0.02 \\
\hline Knife River near Two Harbors, Minn. & 04015330 & 1998 & 6.52 & 6.56 & 6.78 & 12.13 & 0.83 \\
\hline Knife River near Two Harbors, Minn. & 04015330 & 1999 & 10.58 & 10.28 & 9.78 & 11.52 & 0.13 \\
\hline Knife River near Two Harbors, Minn. & 04015330 & 2000 & 5.33 & 5.38 & 5.14 & 4.55 & -0.14 \\
\hline Knife River near Two Harbors, Minn. & 04015330 & 2001 & 8.64 & 8.84 & 9.79 & 10.92 & 0.20 \\
\hline Knife River near Two Harbors, Minn. & 04015330 & 2002 & 4.95 & 5.84 & 5.54 & 6.33 & 0.16 \\
\hline Knife River near Two Harbors, Minn. & 04015330 & 2003 & 3.68 & 4.37 & 4.30 & 3.16 & -0.23 \\
\hline Knife River near Two Harbors, Minn. & 04015330 & 2004 & 5.65 & 5.40 & 5.78 & 7.64 & 0.36 \\
\hline Knife River near Two Harbors, Minn. & 04015330 & 2005 & 9.29 & 9.11 & 8.69 & 9.46 & 0.05 \\
\hline Knife River near Two Harbors, Minn. & 04015330 & 2006 & 6.20 & 7.30 & 6.71 & 3.89 & -0.42 \\
\hline Knife River near Two Harbors, Minn. & 04015330 & 2007 & 7.10 & 8.07 & 7.47 & 11.63 & 0.54 \\
\hline Knife River near Two Harbors, Minn. & 04015330 & 2008 & 7.68 & 7.75 & 7.75 & 9.79 & 0.27 \\
\hline Knife River near Two Harbors, Minn. & 04015330 & 2009 & 6.99 & 7.69 & 7.75 & 8.42 & 0.13 \\
\hline Knife River near Two Harbors, Minn. & 04015330 & 2010 & 8.03 & 8.80 & 8.26 & 7.44 & -0.11 \\
\hline Otter Tail River below Orwell Dam near Fergus Falls, Minn. & 05046000 & 1996 & 3.60 & 3.54 & 3.51 & 2.00 & -0.44 \\
\hline Otter Tail River below Orwell Dam near Fergus Falls, Minn. & 05046000 & 1997 & 5.44 & 5.39 & 5.40 & 7.35 & 0.36 \\
\hline Otter Tail River below Orwell Dam near Fergus Falls, Minn. & 05046000 & 1998 & 4.61 & 4.70 & 4.67 & 6.70 & 0.44 \\
\hline Otter Tail River below Orwell Dam near Fergus Falls, Minn. & 05046000 & 1999 & 6.05 & 6.00 & 5.98 & 4.18 & -0.30 \\
\hline Otter Tail River below Orwell Dam near Fergus Falls, Minn. & 05046000 & 2000 & 4.43 & 4.36 & 4.36 & 2.83 & -0.35 \\
\hline Otter Tail River below Orwell Dam near Fergus Falls, Minn. & 05046000 & 2001 & 5.66 & 5.57 & 5.52 & 3.45 & -0.38 \\
\hline Otter Tail River below Orwell Dam near Fergus Falls, Minn. & 05046000 & 2002 & 3.68 & 3.63 & 3.62 & 2.62 & -0.28 \\
\hline Otter Tail River below Orwell Dam near Fergus Falls, Minn. & 05046000 & 2003 & 2.54 & 2.46 & 2.47 & 1.08 & -0.57 \\
\hline Otter Tail River below Orwell Dam near Fergus Falls, Minn. & 05046000 & 2004 & 3.38 & 3.28 & 3.26 & 5.85 & 0.77 \\
\hline Otter Tail River below Orwell Dam near Fergus Falls, Minn. & 05046000 & 2005 & 5.61 & 5.46 & 5.48 & 3.16 & -0.43 \\
\hline Otter Tail River below Orwell Dam near Fergus Falls, Minn. & 05046000 & 2006 & 5.03 & 4.94 & 4.88 & 2.99 & -0.40 \\
\hline Otter Tail River below Orwell Dam near Fergus Falls, Minn. & 05046000 & 2007 & 4.65 & 4.49 & 4.46 & 4.75 & 0.05 \\
\hline Otter Tail River below Orwell Dam near Fergus Falls, Minn. & 05046000 & 2008 & 4.39 & 4.29 & 4.28 & 5.07 & 0.17 \\
\hline
\end{tabular}


Table 2-1. Annual mean base-flow estimates rates from 1996-2010 using three hydrograph separation techniques for the 35 streamgages used in model calibration analysis in comparison to the estimated annual potential recharge rates for the same period from the Soil-Water-Balance (SWB) model.-Continued

\begin{tabular}{|c|c|c|c|c|c|c|c|}
\hline \multirow[b]{2}{*}{ USGS streamgage name or statistic } & \multirow{2}{*}{$\begin{array}{c}\text { USGS } \\
\text { streamgage } \\
\text { number }\end{array}$} & \multirow[b]{2}{*}{ Year } & \multicolumn{3}{|c|}{ Base-flow estimate (in/yr) } & \multirow{2}{*}{$\begin{array}{c}\text { Potential recharge rate } \\
\text { from SWB model } \\
\text { (in/yr) }\end{array}$} & \multirow[b]{2}{*}{ Relative error ${ }^{c}$} \\
\hline & & & $\begin{array}{l}\text { PART } \\
\text { (in/yr) }\end{array}$ & $\begin{array}{l}\text { HYSEP fixed- } \\
\text { interval method }\end{array}$ & $\begin{array}{l}\text { HYSEP sliding } \\
\text { method }^{b}\end{array}$ & & \\
\hline Otter Tail River below Orwell Dam near Fergus Falls, Minn. & 05046000 & 2009 & 7.04 & 6.81 & 6.84 & 6.76 & -0.02 \\
\hline Otter Tail River below Orwell Dam near Fergus Falls, Minn. & 05046000 & 2010 & 8.88 & 8.72 & 8.72 & 8.58 & -0.02 \\
\hline Buffalo River near Dilworth, Minn. & 05062000 & 1996 & 2.29 & 2.02 & 2.06 & 1.69 & -0.21 \\
\hline Buffalo River near Dilworth, Minn. & 05062000 & 1997 & 4.67 & 4.04 & 4.24 & 6.38 & 0.48 \\
\hline Buffalo River near Dilworth, Minn. & 05062000 & 1998 & 5.13 & 4.49 & 4.55 & 7.79 & 0.65 \\
\hline Buffalo River near Dilworth, Minn. & 05062000 & 1999 & 3.30 & 3.19 & 3.13 & 3.35 & 0.05 \\
\hline Buffalo River near Dilworth, Minn. & 05062000 & 2000 & 3.55 & 3.71 & 3.48 & 2.65 & -0.26 \\
\hline Buffalo River near Dilworth, Minn. & 05062000 & 2001 & 3.97 & 3.78 & 3.89 & 2.63 & -0.32 \\
\hline Buffalo River near Dilworth, Minn. & 05062000 & 2002 & 1.74 & 1.71 & 1.81 & 1.21 & -0.31 \\
\hline Buffalo River near Dilworth, Minn. & 05062000 & 2003 & 1.25 & 1.35 & 1.37 & 0.72 & -0.45 \\
\hline Buffalo River near Dilworth, Minn. & 05062000 & 2004 & 2.80 & 2.65 & 2.63 & 5.05 & 0.87 \\
\hline Buffalo River near Dilworth, Minn. & 05062000 & 2005 & 2.94 & 3.34 & 3.23 & 3.01 & -0.05 \\
\hline Buffalo River near Dilworth, Minn. & 05062000 & 2006 & 3.02 & 2.31 & 2.57 & 2.72 & 0.03 \\
\hline Buffalo River near Dilworth, Minn. & 05062000 & 2007 & 2.54 & 2.52 & 2.60 & 4.01 & 0.57 \\
\hline Buffalo River near Dilworth, Minn. & 05062000 & 2008 & 3.52 & 3.68 & 3.69 & 5.16 & 0.42 \\
\hline Buffalo River near Dilworth, Minn. & 05062000 & 2009 & 6.04 & 5.39 & 5.76 & 6.60 & 0.15 \\
\hline Buffalo River near Dilworth, Minn. & 05062000 & 2010 & 5.29 & 4.89 & 5.00 & 7.73 & 0.53 \\
\hline Wild River River at Twin Valley, Minn. & 05062500 & 1996 & 3.81 & 3.79 & 3.86 & 1.52 & -0.60 \\
\hline Wild River River at Twin Valley, Minn. & 05062500 & 1997 & 5.37 & 4.87 & 5.07 & 7.87 & 0.54 \\
\hline Wild River River at Twin Valley, Minn. & 05062500 & 1998 & 4.38 & 4.04 & 4.10 & 5.83 & 0.40 \\
\hline Wild River River at Twin Valley, Minn. & 05062500 & 1999 & 6.74 & 6.52 & 6.49 & 5.51 & -0.16 \\
\hline Wild River River at Twin Valley, Minn. & 05062500 & 2000 & 4.96 & 4.79 & 4.64 & 3.90 & -0.19 \\
\hline Wild River River at Twin Valley, Minn. & 05062500 & 2001 & 4.91 & 4.84 & 4.98 & 2.90 & -0.41 \\
\hline Wild River River at Twin Valley, Minn. & 05062500 & 2003 & 2.14 & 2.02 & 2.03 & 0.45 & -0.78 \\
\hline Wild River River at Twin Valley, Minn. & 05062500 & 2004 & 3.58 & 3.13 & 3.26 & 6.21 & 0.87 \\
\hline Wild River River at Twin Valley, Minn. & 05062500 & 2005 & 4.30 & 3.96 & 3.98 & 1.88 & -0.54 \\
\hline Wild River River at Twin Valley, Minn. & 05062500 & 2006 & 3.05 & 2.87 & 2.71 & 3.02 & 0.05 \\
\hline Wild River River at Twin Valley, Minn. & 05062500 & 2007 & 2.47 & 2.57 & 2.41 & 4.16 & 0.67 \\
\hline Wild River River at Twin Valley, Minn. & 05062500 & 2008 & 4.06 & 3.95 & 3.88 & 5.25 & 0.32 \\
\hline
\end{tabular}


Table 2-1. Annual mean base-flow estimates rates from 1996-2010 using three hydrograph separation techniques for the 35 streamgages used in model calibration analysis in comparison to the estimated annual potential recharge rates for the same period from the Soil-Water-Balance (SWB) model.-Continued

\begin{tabular}{|c|c|c|c|c|c|c|c|}
\hline \multirow[b]{2}{*}{ USGS streamgage name or statistic } & \multirow{2}{*}{$\begin{array}{c}\text { USGS } \\
\text { streamgage } \\
\text { number }\end{array}$} & \multirow[b]{2}{*}{ Year } & \multicolumn{3}{|c|}{ Base-flow estimate (in/yr) } & \multirow{2}{*}{$\begin{array}{c}\text { Potential recharge rate } \\
\text { from SWB model } \\
\text { (in/yr) }\end{array}$} & \multirow[b]{2}{*}{ Relative error ${ }^{c}$} \\
\hline & & & $\begin{array}{l}\text { PART } \\
\text { (in/yr) }\end{array}$ & $\begin{array}{l}\text { HYSEP fixed- } \\
\text { interval method }\end{array}$ & $\begin{array}{l}\text { HYSEP sliding } \\
\text { method }^{b}\end{array}$ & & \\
\hline Wild River River at Twin Valley, Minn. & 05062500 & 2009 & 5.49 & 5.49 & 5.53 & 5.81 & 0.06 \\
\hline Wild River River at Twin Valley, Minn. & 05062500 & 2010 & 5.54 & 4.86 & 5.02 & 7.83 & 0.52 \\
\hline Sand Hill River at Climax, Minn. & 05069000 & 1996 & 1.29 & 2.51 & 2.52 & 1.00 & -0.53 \\
\hline Sand Hill River at Climax, Minn. & 05069000 & 1997 & 4.18 & 4.51 & 4.51 & 5.78 & 0.31 \\
\hline Sand Hill River at Climax, Minn. & 05069000 & 1998 & 3.65 & 3.80 & 3.51 & 5.78 & 0.58 \\
\hline Sand Hill River at Climax, Minn. & 05069000 & 1999 & 6.04 & 5.58 & 5.43 & 3.05 & -0.46 \\
\hline Sand Hill River at Climax, Minn. & 05069000 & 2000 & 2.70 & 2.39 & 2.40 & 3.61 & 0.45 \\
\hline Sand Hill River at Climax, Minn. & 05069000 & 2001 & 2.53 & 2.74 & 2.51 & 2.28 & -0.12 \\
\hline Sand Hill River at Climax, Minn. & 05069000 & 2002 & 3.49 & 3.02 & 3.23 & 3.28 & 0.01 \\
\hline Sand Hill River at Climax, Minn. & 05069000 & 2003 & 1.45 & 1.28 & 1.34 & 0.19 & -0.86 \\
\hline Sand Hill River at Climax, Minn. & 05069000 & 2004 & 2.46 & 2.41 & 2.21 & 4.34 & 0.84 \\
\hline Sand Hill River at Climax, Minn. & 05069000 & 2005 & 2.93 & 2.62 & 2.69 & 2.67 & -0.03 \\
\hline Sand Hill River at Climax, Minn. & 05069000 & 2006 & 2.06 & 2.71 & 2.55 & 2.14 & -0.12 \\
\hline Sand Hill River at Climax, Minn. & 05069000 & 2007 & 2.11 & 1.95 & 1.83 & 2.69 & 0.37 \\
\hline Sand Hill River at Climax, Minn. & 05069000 & 2008 & 2.40 & 2.17 & 2.18 & 4.68 & 1.08 \\
\hline Sand Hill River at Climax, Minn. & 05069000 & 2009 & 4.36 & 4.33 & 4.20 & 6.11 & 0.42 \\
\hline Sand Hill River at Climax, Minn. & 05069000 & 2010 & 4.93 & 4.22 & 4.39 & 6.10 & 0.35 \\
\hline Red Lake River near Red Lake, Minn. & 05074500 & 2000 & 4.78 & 5.24 & 5.15 & 3.43 & -0.32 \\
\hline Red Lake River near Red Lake, Minn. & 05074500 & 2001 & 5.01 & 5.22 & 5.28 & 5.84 & 0.13 \\
\hline Red Lake River near Red Lake, Minn. & 05074500 & 2002 & 4.72 & 5.01 & 4.94 & 3.84 & -0.21 \\
\hline Red Lake River near Red Lake, Minn. & 05074500 & 2003 & 0.58 & 0.59 & 0.59 & 0.29 & -0.51 \\
\hline Red Lake River near Red Lake, Minn. & 05074500 & 2004 & 1.32 & 1.47 & 1.49 & 5.29 & 2.71 \\
\hline Red Lake River near Red Lake, Minn. & 05074500 & 2005 & 5.04 & 5.09 & 5.10 & 2.89 & -0.43 \\
\hline Red Lake River near Red Lake, Minn. & 05074500 & 2006 & 2.84 & 2.96 & 2.98 & 2.90 & -0.01 \\
\hline Red Lake River near Red Lake, Minn. & 05074500 & 2007 & 0.90 & 0.92 & 0.92 & 3.59 & 2.93 \\
\hline Red Lake River near Red Lake, Minn. & 05074500 & 2008 & 1.09 & 1.13 & 1.13 & 3.10 & 1.78 \\
\hline Red Lake River near Red Lake, Minn. & 05074500 & 2009 & 2.54 & 2.54 & 2.55 & 5.02 & 0.97 \\
\hline Red Lake River near Red Lake, Minn. & 05074500 & 2010 & 3.29 & 3.29 & 3.23 & 4.71 & 0.44 \\
\hline
\end{tabular}


Table 2-1. Annual mean base-flow estimates rates from 1996-2010 using three hydrograph separation techniques for the 35 streamgages used in model calibration analysis in comparison to the estimated annual potential recharge rates for the same period from the Soil-Water-Balance (SWB) model.-Continued

\begin{tabular}{|c|c|c|c|c|c|c|c|}
\hline \multirow[b]{2}{*}{ USGS streamgage name or statistic } & \multirow{2}{*}{$\begin{array}{c}\text { USGS } \\
\text { streamgage } \\
\text { number }\end{array}$} & \multirow[b]{2}{*}{ Year } & \multicolumn{3}{|c|}{ Base-flow estimate (in/yr) } & \multirow{2}{*}{$\begin{array}{c}\text { Potential recharge rate } \\
\text { from SWB model } \\
\text { (in/yr) }\end{array}$} & \multirow[b]{2}{*}{ Relative error ${ }^{\mathrm{c}}$} \\
\hline & & & $\begin{array}{l}\text { PARTa } \\
\text { (in/yr) }\end{array}$ & $\begin{array}{l}\text { HYSEP fixed- } \\
\text { interval method }\end{array}$ & $\begin{array}{l}\text { HYSEP sliding } \\
\text { method }^{b}\end{array}$ & & \\
\hline Thief River near Thief River Falls, Minn. & 05076000 & 1996 & 5.36 & 4.96 & 5.18 & 2.29 & -0.56 \\
\hline Thief River near Thief River Falls, Minn. & 05076000 & 1997 & 6.01 & 5.47 & 5.60 & 4.82 & -0.15 \\
\hline Thief River near Thief River Falls, Minn. & 05076000 & 1998 & 2.90 & 2.82 & 2.74 & 4.00 & 0.42 \\
\hline Thief River near Thief River Falls, Minn. & 05076000 & 1999 & 8.57 & 8.66 & 8.58 & 4.94 & -0.43 \\
\hline Thief River near Thief River Falls, Minn. & 05076000 & 2001 & 4.87 & 4.53 & 4.67 & 3.91 & -0.17 \\
\hline Thief River near Thief River Falls, Minn. & 05076000 & 2002 & 5.48 & 5.24 & 5.08 & 4.78 & -0.09 \\
\hline Thief River near Thief River Falls, Minn. & 05076000 & 2003 & 0.30 & 0.32 & 0.30 & 0.32 & 0.04 \\
\hline Thief River near Thief River Falls, Minn. & 05076000 & 2004 & 5.67 & 5.42 & 5.48 & 5.11 & -0.08 \\
\hline Thief River near Thief River Falls, Minn. & 05076000 & 2005 & 5.35 & 5.12 & 5.02 & 1.54 & -0.70 \\
\hline Thief River near Thief River Falls, Minn. & 05076000 & 2008 & 0.84 & 0.98 & 0.93 & 3.23 & 2.52 \\
\hline Thief River near Thief River Falls, Minn. & 05076000 & 2009 & 4.09 & 4.64 & 4.53 & 4.49 & 0.02 \\
\hline Thief River near Thief River Falls, Minn. & 05076000 & 2010 & 5.82 & 5.47 & 5.48 & 7.56 & 0.35 \\
\hline Clearwater River at Plummer, Minn. & 05078000 & 1996 & 4.71 & 4.66 & 4.83 & 1.49 & -0.69 \\
\hline Clearwater River at Plummer, Minn. & 05078000 & 1997 & 6.67 & 5.93 & 6.04 & 5.75 & -0.07 \\
\hline Clearwater River at Plummer, Minn. & 05078000 & 1998 & 2.94 & 2.73 & 2.77 & 3.75 & 0.33 \\
\hline Clearwater River at Plummer, Minn. & 05078000 & 1999 & 5.97 & 5.50 & 5.47 & 5.22 & -0.08 \\
\hline Clearwater River at Plummer, Minn. & 05078000 & 2000 & 4.26 & 4.06 & 3.96 & 3.64 & -0.11 \\
\hline Clearwater River at Plummer, Minn. & 05078000 & 2001 & 5.70 & 5.34 & 5.46 & 3.40 & -0.38 \\
\hline Clearwater River at Plummer, Minn. & 05078000 & 2002 & 3.50 & 3.29 & 3.39 & 4.09 & 0.21 \\
\hline Clearwater River at Plummer, Minn. & 05078000 & 2003 & 1.66 & 1.60 & 1.58 & 0.20 & -0.88 \\
\hline Clearwater River at Plummer, Minn. & 05078000 & 2004 & 2.81 & 2.49 & 2.54 & 4.53 & 0.73 \\
\hline Clearwater River at Plummer, Minn. & 05078000 & 2005 & 3.47 & 3.71 & 3.53 & 1.77 & -0.51 \\
\hline Clearwater River at Plummer, Minn. & 05078000 & 2006 & 2.67 & 2.13 & 2.35 & 2.50 & 0.05 \\
\hline Clearwater River at Plummer, Minn. & 05078000 & 2007 & 2.74 & 2.21 & 2.39 & 3.38 & 0.38 \\
\hline Clearwater River at Plummer, Minn. & 05078000 & 2008 & 2.64 & 2.55 & 2.61 & 3.44 & 0.32 \\
\hline Clearwater River at Plummer, Minn. & 05078000 & 2009 & 5.68 & 5.20 & 5.12 & 4.67 & -0.12 \\
\hline Clearwater River at Plummer, Minn. & 05078000 & 2010 & 5.08 & 4.49 & 4.48 & 6.53 & 0.39 \\
\hline Lost River at Oklee, Minn. & 05078230 & 1996 & 3.89 & 4.43 & 3.89 & 1.04 & -0.74 \\
\hline Lost River at Oklee, Minn. & 05078230 & 1997 & 4.26 & 3.94 & 4.01 & 4.94 & 0.21 \\
\hline
\end{tabular}


Table 2-1. Annual mean base-flow estimates rates from 1996-2010 using three hydrograph separation techniques for the 35 streamgages used in model calibration analysis in comparison to the estimated annual potential recharge rates for the same period from the Soil-Water-Balance (SWB) model.-Continued

\begin{tabular}{|c|c|c|c|c|c|c|c|}
\hline \multirow[b]{2}{*}{ USGS streamgage name or statistic } & \multirow{2}{*}{$\begin{array}{c}\text { USGS } \\
\text { streamgage } \\
\text { number }\end{array}$} & \multirow[b]{2}{*}{ Year } & \multicolumn{3}{|c|}{ Base-flow estimate (in/yr) } & \multirow{2}{*}{$\begin{array}{l}\text { Potential recharge rate } \\
\text { from SWB model } \\
\text { (in/yr) }\end{array}$} & \multirow[b]{2}{*}{ Relative error $^{c}$} \\
\hline & & & $\begin{array}{l}\text { PART }^{a} \\
\text { (in/yr) }\end{array}$ & $\begin{array}{l}\text { HYSEP fixed- } \\
\text { interval method }\end{array}$ & $\begin{array}{l}\text { HYSEP sliding } \\
\text { method }^{b}\end{array}$ & & \\
\hline Lost River at Oklee, Minn. & 05078230 & 1998 & 2.25 & 2.23 & 2.17 & 3.54 & 0.59 \\
\hline Lost River at Oklee, Minn. & 05078230 & 1999 & 4.76 & 4.45 & 4.55 & 4.25 & -0.07 \\
\hline Lost River at Oklee, Minn. & 05078230 & 2000 & 2.66 & 2.46 & 2.43 & 3.43 & 0.36 \\
\hline Lost River at Oklee, Minn. & 05078230 & 2001 & 4.21 & 3.49 & 3.64 & 3.11 & -0.18 \\
\hline Lost River at Oklee, Minn. & 05078230 & 2002 & 2.32 & 2.02 & 2.17 & 3.82 & 0.76 \\
\hline Lost River at Oklee, Minn. & 05078230 & 2003 & 1.14 & 1.04 & 0.99 & 0.14 & -0.86 \\
\hline Lost River at Oklee, Minn. & 05078230 & 2004 & 2.50 & 2.10 & 2.18 & 4.27 & 0.89 \\
\hline Lost River at Oklee, Minn. & 05078230 & 2005 & 2.99 & 2.74 & 2.69 & 1.50 & -0.46 \\
\hline Lost River at Oklee, Minn. & 05078230 & 2006 & 1.79 & 1.39 & 1.53 & 2.26 & 0.44 \\
\hline Lost River at Oklee, Minn. & 05078230 & 2007 & 1.95 & 1.70 & 1.83 & 2.88 & 0.58 \\
\hline Lost River at Oklee, Minn. & 05078230 & 2008 & 2.40 & 2.14 & 2.16 & 2.55 & 0.14 \\
\hline Lost River at Oklee, Minn. & 05078230 & 2009 & 4.48 & 3.88 & 4.05 & 4.51 & 0.09 \\
\hline Lost River at Oklee, Minn. & 05078230 & 2010 & 3.58 & 3.26 & 3.33 & 6.43 & 0.90 \\
\hline Middle River at Argyle, Minn. & 05087500 & 1996 & 2.52 & 2.07 & 2.40 & 2.69 & 0.15 \\
\hline Middle River at Argyle, Minn. & 05087500 & 1997 & 4.41 & 2.81 & 3.20 & 4.80 & 0.38 \\
\hline Middle River at Argyle, Minn. & 05087500 & 1998 & 2.85 & 2.16 & 2.44 & 3.43 & 0.38 \\
\hline Middle River at Argyle, Minn. & 05087500 & 1999 & 5.70 & 5.91 & 5.63 & 2.21 & -0.62 \\
\hline Middle River at Argyle, Minn. & 05087500 & 2000 & 3.03 & 2.88 & 3.10 & 3.44 & 0.14 \\
\hline Middle River at Argyle, Minn. & 05087500 & 2001 & 3.16 & 2.65 & 2.77 & 2.82 & -0.01 \\
\hline Middle River at Argyle, Minn. & 05087500 & 2002 & 2.23 & 1.97 & 1.80 & 4.15 & 1.08 \\
\hline Middle River at Argyle, Minn. & 05087500 & 2003 & 0.70 & 0.58 & 0.58 & 0.20 & -0.68 \\
\hline Middle River at Argyle, Minn. & 05087500 & 2004 & 3.34 & 3.15 & 2.74 & 3.99 & 0.30 \\
\hline Middle River at Argyle, Minn. & 05087500 & 2005 & 3.76 & 4.27 & 4.03 & 0.94 & -0.77 \\
\hline Middle River at Argyle, Minn. & 05087500 & 2006 & 3.25 & 1.87 & 2.25 & 2.49 & 0.01 \\
\hline Middle River at Argyle, Minn. & 05087500 & 2007 & 1.70 & 1.36 & 1.48 & 3.15 & 1.08 \\
\hline Middle River at Argyle, Minn. & 05087500 & 2008 & 1.66 & 1.30 & 1.36 & 4.59 & 2.19 \\
\hline Middle River at Argyle, Minn. & 05087500 & 2009 & 3.89 & 3.75 & 3.94 & 4.35 & 0.13 \\
\hline Middle River at Argyle, Minn. & 05087500 & 2010 & 4.19 & 3.54 & 3.65 & 8.22 & 1.17 \\
\hline
\end{tabular}


Table 2-1. Annual mean base-flow estimates rates from 1996-2010 using three hydrograph separation techniques for the 35 streamgages used in model calibration analysis in comparison to the estimated annual potential recharge rates for the same period from the Soil-Water-Balance (SWB) model.-Continued

\begin{tabular}{|c|c|c|c|c|c|c|c|}
\hline \multirow[b]{2}{*}{ USGS streamgage name or statistic } & \multirow{2}{*}{$\begin{array}{c}\text { USGS } \\
\text { streamgage } \\
\text { number }\end{array}$} & \multirow[b]{2}{*}{ Year } & \multicolumn{3}{|c|}{ Base-flow estimate (in/yr) } & \multirow{2}{*}{$\begin{array}{c}\text { Potential recharge rate } \\
\text { from SWB model } \\
\text { (in/yr) }\end{array}$} & \multirow[b]{2}{*}{ Relative error ${ }^{c}$} \\
\hline & & & $\begin{array}{l}\text { PARTa } \\
\text { (in/yr) }\end{array}$ & $\begin{array}{l}\text { HYSEP fixed- } \\
\text { interval method }^{b}\end{array}$ & $\begin{array}{l}\text { HYSEP sliding } \\
\text { method }^{b}\end{array}$ & & \\
\hline South Branch Two Rivers at Lake Bronson, Minn. & 05094000 & 1996 & 5.54 & 5.72 & 5.60 & 2.93 & -0.48 \\
\hline South Branch Two Rivers at Lake Bronson, Minn. & 05094000 & 1997 & 4.34 & 3.40 & 3.38 & 5.08 & 0.37 \\
\hline South Branch Two Rivers at Lake Bronson, Minn. & 05094000 & 1998 & 1.45 & 1.83 & 1.78 & 3.52 & 1.09 \\
\hline South Branch Two Rivers at Lake Bronson, Minn. & 05094000 & 1999 & 5.89 & 4.69 & 5.19 & 1.90 & -0.64 \\
\hline South Branch Two Rivers at Lake Bronson, Minn. & 05094000 & 2000 & 2.59 & 2.79 & 3.03 & 5.49 & 0.96 \\
\hline South Branch Two Rivers at Lake Bronson, Minn. & 05094000 & 2001 & 4.39 & 4.15 & 4.25 & 3.00 & -0.30 \\
\hline South Branch Two Rivers at Lake Bronson, Minn. & 05094000 & 2002 & 3.46 & 3.16 & 3.45 & 4.31 & 0.28 \\
\hline South Branch Two Rivers at Lake Bronson, Minn. & 05094000 & 2003 & 0.38 & 0.52 & 0.48 & 0.29 & -0.37 \\
\hline South Branch Two Rivers at Lake Bronson, Minn. & 05094000 & 2004 & 5.28 & 4.92 & 5.01 & 4.81 & -0.05 \\
\hline South Branch Two Rivers at Lake Bronson, Minn. & 05094000 & 2005 & 5.09 & 5.43 & 5.02 & 2.80 & -0.46 \\
\hline South Branch Two Rivers at Lake Bronson, Minn. & 05094000 & 2006 & 2.84 & 3.42 & 2.91 & 3.08 & 0.01 \\
\hline South Branch Two Rivers at Lake Bronson, Minn. & 05094000 & 2007 & 0.96 & 1.05 & 1.09 & 4.08 & 2.95 \\
\hline South Branch Two Rivers at Lake Bronson, Minn. & 05094000 & 2008 & 0.93 & 0.91 & 0.92 & 2.87 & 2.12 \\
\hline South Branch Two Rivers at Lake Bronson, Minn. & 05094000 & 2009 & 6.74 & 6.19 & 6.12 & 6.25 & -0.02 \\
\hline South Branch Two Rivers at Lake Bronson, Minn. & 05094000 & 2010 & 3.96 & 4.32 & 3.91 & 8.56 & 1.11 \\
\hline Kawishiwi River near Winton, Minn. & 05127000 & 1996 & 9.72 & 13.13 & 12.80 & 8.25 & -0.31 \\
\hline Kawishiwi River near Winton, Minn. & 05127000 & 1997 & 7.05 & 7.33 & 7.40 & 8.47 & 0.17 \\
\hline Kawishiwi River near Winton, Minn. & 05127000 & 1998 & 5.28 & 5.78 & 5.84 & 9.35 & 0.66 \\
\hline Kawishiwi River near Winton, Minn. & 05127000 & 1999 & 11.39 & 11.02 & 11.32 & 9.32 & -0.17 \\
\hline Kawishiwi River near Winton, Minn. & 05127000 & 2000 & 7.28 & 6.45 & 6.64 & 4.18 & -0.38 \\
\hline Kawishiwi River near Winton, Minn. & 05127000 & 2001 & 11.22 & 11.54 & 11.31 & 12.51 & 0.10 \\
\hline Kawishiwi River near Winton, Minn. & 05127000 & 2002 & 4.61 & 4.22 & 4.48 & 3.25 & -0.27 \\
\hline Kawishiwi River near Winton, Minn. & 05127000 & 2003 & 4.50 & 4.27 & 4.29 & 3.20 & -0.26 \\
\hline Kawishiwi River near Winton, Minn. & 05127000 & 2004 & 6.57 & 6.71 & 6.64 & 6.24 & -0.06 \\
\hline Kawishiwi River near Winton, Minn. & 05127000 & 2005 & 6.28 & 6.21 & 6.08 & 8.52 & 0.38 \\
\hline Kawishiwi River near Winton, Minn. & 05127000 & 2007 & 8.31 & 8.42 & 8.39 & 12.49 & 0.49 \\
\hline Kawishiwi River near Winton, Minn. & 05127000 & 2008 & 9.45 & 9.86 & 9.80 & 9.66 & -0.00 \\
\hline Kawishiwi River near Winton, Minn. & 05127000 & 2009 & 6.28 & 6.49 & 6.47 & 7.43 & 0.16 \\
\hline Kawishiwi River near Winton, Minn. & 05127000 & 2010 & 2.35 & 2.24 & 2.27 & 4.72 & 1.06 \\
\hline
\end{tabular}


Table 2-1. Annual mean base-flow estimates rates from 1996-2010 using three hydrograph separation techniques for the 35 streamgages used in model calibration analysis in comparison to the estimated annual potential recharge rates for the same period from the Soil-Water-Balance (SWB) model.-Continued

\begin{tabular}{|c|c|c|c|c|c|c|c|}
\hline \multirow[b]{2}{*}{ USGS streamgage name or statistic } & \multirow{2}{*}{$\begin{array}{c}\text { USGS } \\
\text { streamgage } \\
\text { number }\end{array}$} & \multirow[b]{2}{*}{ Year } & \multicolumn{3}{|c|}{ Base-flow estimate (in/yr) } & \multirow{2}{*}{$\begin{array}{c}\text { Potential recharge rate } \\
\text { from SWB model } \\
\text { (in/yr) }\end{array}$} & \multirow[b]{2}{*}{ Relative error ${ }^{c}$} \\
\hline & & & $\begin{array}{l}\text { PART }^{a} \\
\text { (in/yr) }\end{array}$ & $\begin{array}{l}\text { HYSEP fixed- } \\
\text { interval method }\end{array}$ & $\begin{array}{l}\text { HYSEP sliding } \\
\text { method }^{\mathrm{b}}\end{array}$ & & \\
\hline Little Fork River at Littlefork, Minn. & 05131500 & 1996 & 8.66 & 7.70 & 7.53 & 4.91 & -0.38 \\
\hline Little Fork River at Littlefork, Minn. & 05131500 & 1997 & 6.97 & 6.49 & 6.48 & 6.07 & -0.09 \\
\hline Little Fork River at Littlefork, Minn. & 05131500 & 1998 & 4.05 & 3.69 & 3.65 & 4.12 & 0.09 \\
\hline Little Fork River at Littlefork, Minn. & 05131500 & 1999 & 8.69 & 7.46 & 7.65 & 8.82 & 0.11 \\
\hline Little Fork River at Littlefork, Minn. & 05131500 & 2000 & 5.14 & 4.77 & 4.57 & 2.79 & -0.42 \\
\hline Little Fork River at Littlefork, Minn. & 05131500 & 2001 & 10.72 & 8.89 & 9.54 & 7.82 & -0.20 \\
\hline Little Fork River at Littlefork, Minn. & 05131500 & 2002 & 4.43 & 4.16 & 4.13 & 3.65 & -0.14 \\
\hline Little Fork River at Littlefork, Minn. & 05131500 & 2003 & 3.19 & 2.89 & 2.99 & 1.52 & -0.50 \\
\hline Little Fork River at Littlefork, Minn. & 05131500 & 2004 & 7.17 & 6.46 & 6.22 & 7.35 & 0.11 \\
\hline Little Fork River at Littlefork, Minn. & 05131500 & 2005 & 6.34 & 6.29 & 5.79 & 5.80 & -0.06 \\
\hline Little Fork River at Littlefork, Minn. & 05131500 & 2006 & 4.07 & 3.63 & 3.72 & 3.42 & -0.10 \\
\hline Little Fork River at Littlefork, Minn. & 05131500 & 2007 & 3.71 & 3.24 & 3.23 & 7.02 & 1.07 \\
\hline Little Fork River at Littlefork, Minn. & 05131500 & 2008 & 6.65 & 6.31 & 5.98 & 5.37 & -0.15 \\
\hline Little Fork River at Littlefork, Minn. & 05131500 & 2009 & 6.56 & 5.84 & 6.22 & 7.30 & 0.18 \\
\hline Little Fork River at Littlefork, Minn. & 05131500 & 2010 & 4.75 & 4.28 & 4.30 & 3.97 & -0.11 \\
\hline Big Fork River at Big Falls, Minn. & 05132000 & 1998 & 4.32 & 3.93 & 4.07 & 3.91 & -0.05 \\
\hline Big Fork River at Big Falls, Minn. & 05132000 & 1999 & 8.92 & 8.14 & 8.10 & 8.14 & -0.03 \\
\hline Big Fork River at Big Falls, Minn. & 05132000 & 2000 & 5.07 & 4.51 & 4.59 & 3.05 & -0.35 \\
\hline Big Fork River at Big Falls, Minn. & 05132000 & 2001 & 9.04 & 8.72 & 8.44 & 7.36 & -0.16 \\
\hline Big Fork River at Big Falls, Minn. & 05132000 & 2002 & 4.78 & 4.28 & 4.28 & 3.20 & -0.28 \\
\hline Big Fork River at Big Falls, Minn. & 05132000 & 2003 & 2.44 & 2.22 & 2.21 & 0.57 & -0.75 \\
\hline Big Fork River at Big Falls, Minn. & 05132000 & 2004 & 6.07 & 5.43 & 5.44 & 6.90 & 0.22 \\
\hline Big Fork River at Big Falls, Minn. & 05132000 & 2005 & 6.71 & 6.14 & 6.26 & 5.34 & -0.16 \\
\hline Big Fork River at Big Falls, Minn. & 05132000 & 2006 & 4.41 & 4.14 & 4.11 & 3.14 & -0.26 \\
\hline Big Fork River at Big Falls, Minn. & 05132000 & 2007 & 2.53 & 2.47 & 2.39 & 5.02 & 1.04 \\
\hline Big Fork River at Big Falls, Minn. & 05132000 & 2008 & 4.91 & 4.69 & 4.71 & 4.26 & -0.11 \\
\hline Big Fork River at Big Falls, Minn. & 05132000 & 2009 & 5.63 & 5.25 & 5.15 & 6.45 & 0.21 \\
\hline Big Fork River at Big Falls, Minn. & 05132000 & 2010 & 5.86 & 5.42 & 5.32 & 3.49 & -0.37 \\
\hline
\end{tabular}


Table 2-1. Annual mean base-flow estimates rates from 1996-2010 using three hydrograph separation techniques for the 35 streamgages used in model calibration analysis in comparison to the estimated annual potential recharge rates for the same period from the Soil-Water-Balance (SWB) model.-Continued

\begin{tabular}{|c|c|c|c|c|c|c|c|}
\hline \multirow[b]{2}{*}{ USGS streamgage name or statistic } & \multirow{2}{*}{$\begin{array}{c}\text { USGS } \\
\text { streamgage } \\
\text { number }\end{array}$} & \multirow[b]{2}{*}{ Year } & \multicolumn{3}{|c|}{ Base-flow estimate (in/yr) } & \multirow{2}{*}{$\begin{array}{l}\text { Potential recharge rate } \\
\text { from SWB model } \\
\text { (in/yr) }\end{array}$} & \multirow[b]{2}{*}{ Relative error } \\
\hline & & & $\begin{array}{l}\text { PART }^{a} \\
\text { (in/yr) }\end{array}$ & $\begin{array}{l}\text { HYSEP fixed- } \\
\text { interval method }\end{array}$ & $\begin{array}{l}\text { HYSEP sliding } \\
\text { method }^{\mathrm{b}}\end{array}$ & & \\
\hline Crow Wing River at Nimrod, Minn. & 05244000 & 1996 & 6.82 & 6.56 & 6.57 & 2.88 & -0.57 \\
\hline Crow Wing River at Nimrod, Minn. & 05244000 & 1997 & 7.86 & 7.69 & 7.68 & 9.63 & 0.24 \\
\hline Crow Wing River at Nimrod, Minn. & 05244000 & 1998 & 7.24 & 6.90 & 6.89 & 5.84 & -0.17 \\
\hline Crow Wing River at Nimrod, Minn. & 05244000 & 1999 & 8.69 & 8.26 & 8.25 & 7.25 & -0.14 \\
\hline Crow Wing River at Nimrod, Minn. & 05244000 & 2000 & 6.67 & 6.55 & 6.57 & 4.55 & -0.31 \\
\hline Crow Wing River at Nimrod, Minn. & 05244000 & 2001 & 6.86 & 6.48 & 6.52 & 5.15 & -0.22 \\
\hline Crow Wing River at Nimrod, Minn. & 05244000 & 2002 & 5.27 & 5.07 & 5.05 & 4.18 & -0.18 \\
\hline Crow Wing River at Nimrod, Minn. & 05244000 & 2003 & 3.98 & 3.78 & 3.79 & 0.77 & -0.80 \\
\hline Crow Wing River at Nimrod, Minn. & 05244000 & 2004 & 4.56 & 4.47 & 4.42 & 6.75 & 0.51 \\
\hline Crow Wing River at Nimrod, Minn. & 05244000 & 2005 & 5.96 & 5.83 & 5.80 & 3.94 & -0.33 \\
\hline Crow Wing River at Nimrod, Minn. & 05244000 & 2006 & 4.94 & 4.73 & 4.73 & 3.57 & -0.26 \\
\hline Crow Wing River at Nimrod, Minn. & 05244000 & 2007 & 5.15 & 4.84 & 4.82 & 6.20 & 0.26 \\
\hline Crow Wing River at Nimrod, Minn. & 05244000 & 2008 & 5.49 & 5.33 & 5.35 & 6.53 & 0.21 \\
\hline Crow Wing River at Nimrod, Minn. & 05244000 & 2009 & 6.87 & 6.73 & 6.70 & 6.74 & -0.00 \\
\hline Crow Wing River at Nimrod, Minn. & 05244000 & 2010 & 6.67 & 6.44 & 6.39 & 6.79 & 0.04 \\
\hline Long Prairie River at Long Prairie, Minn. & 05245100 & 1996 & 5.92 & 5.56 & 5.54 & 2.51 & -0.56 \\
\hline Long Prairie River at Long Prairie, Minn. & 05245100 & 1997 & 5.80 & 5.75 & 5.65 & 5.42 & -0.05 \\
\hline Long Prairie River at Long Prairie, Minn. & 05245100 & 1998 & 4.43 & 4.30 & 4.30 & 3.82 & -0.12 \\
\hline Long Prairie River at Long Prairie, Minn. & 05245100 & 1999 & 6.16 & 6.04 & 6.00 & 2.37 & -0.61 \\
\hline Long Prairie River at Long Prairie, Minn. & 05245100 & 2000 & 3.17 & 3.07 & 3.04 & 1.45 & -0.53 \\
\hline Long Prairie River at Long Prairie, Minn. & 05245100 & 2001 & 8.02 & 7.25 & 7.42 & 5.30 & -0.30 \\
\hline Long Prairie River at Long Prairie, Minn. & 05245100 & 2002 & 4.84 & 4.65 & 4.56 & 4.06 & -0.13 \\
\hline Long Prairie River at Long Prairie, Minn. & 05245100 & 2003 & 5.49 & 5.09 & 5.15 & 2.23 & -0.57 \\
\hline Long Prairie River at Long Prairie, Minn. & 05245100 & 2004 & 3.07 & 2.95 & 2.95 & 2.47 & -0.18 \\
\hline Long Prairie River at Long Prairie, Minn. & 05245100 & 2005 & 6.40 & 6.13 & 6.13 & 6.61 & 0.06 \\
\hline Long Prairie River at Long Prairie, Minn. & 05245100 & 2006 & 4.65 & 4.48 & 4.43 & 2.26 & -0.50 \\
\hline Long Prairie River at Long Prairie, Minn. & 05245100 & 2007 & 4.11 & 3.90 & 3.90 & 5.46 & 0.37 \\
\hline Long Prairie River at Long Prairie, Minn. & 05245100 & 2008 & 4.41 & 4.28 & 4.29 & 3.21 & -0.26 \\
\hline Long Prairie River at Long Prairie, Minn. & 05245100 & 2009 & 5.57 & 5.18 & 5.23 & 6.98 & 0.31 \\
\hline Long Prairie River at Long Prairie, Minn. & 05245100 & 2010 & 6.47 & 6.19 & 6.24 & 9.18 & 0.46 \\
\hline
\end{tabular}


Table 2-1. Annual mean base-flow estimates rates from 1996-2010 using three hydrograph separation techniques for the 35 streamgages used in model calibration analysis in comparison to the estimated annual potential recharge rates for the same period from the Soil-Water-Balance (SWB) model.-Continued

\begin{tabular}{|c|c|c|c|c|c|c|c|}
\hline \multirow[b]{2}{*}{ USGS streamgage name or statistic } & \multirow{2}{*}{$\begin{array}{c}\text { USGS } \\
\text { streamgage } \\
\text { number }\end{array}$} & \multirow[b]{2}{*}{ Year } & \multicolumn{3}{|c|}{ Base-flow estimate (in/yr) } & \multirow{2}{*}{$\begin{array}{c}\text { Potential recharge rate } \\
\text { from SWB model } \\
\text { (in/yr) }\end{array}$} & \multirow[b]{2}{*}{ Relative error ${ }^{c}$} \\
\hline & & & $\begin{array}{l}\text { PART }^{a} \\
\text { (in/yr) }\end{array}$ & $\begin{array}{l}\text { HYSEP fixed- } \\
\text { interval method }\end{array}$ & $\begin{array}{l}\text { HYSEP sliding } \\
\text { method }^{b}\end{array}$ & & \\
\hline Sauk River near St. Cloud, Minn. & 05270500 & 1996 & 5.44 & 5.48 & 5.54 & 2.35 & -0.57 \\
\hline Sauk River near St. Cloud, Minn. & 05270500 & 1997 & 6.16 & 5.89 & 5.57 & 5.74 & -0.02 \\
\hline Sauk River near St. Cloud, Minn. & 05270500 & 1998 & 4.33 & 4.11 & 4.16 & 3.46 & -0.18 \\
\hline Sauk River near St. Cloud, Minn. & 05270500 & 1999 & 4.00 & 3.89 & 3.90 & 2.43 & -0.38 \\
\hline Sauk River near St. Cloud, Minn. & 05270500 & 2000 & 1.74 & 1.67 & 1.66 & 1.61 & -0.05 \\
\hline Sauk River near St. Cloud, Minn. & 05270500 & 2001 & 6.59 & 6.08 & 6.13 & 7.50 & 0.20 \\
\hline Sauk River near St. Cloud, Minn. & 05270500 & 2002 & 5.50 & 5.26 & 5.26 & 8.03 & 0.50 \\
\hline Sauk River near St. Cloud, Minn. & 05270500 & 2003 & 4.36 & 4.11 & 4.08 & 2.27 & -0.46 \\
\hline Sauk River near St. Cloud, Minn. & 05270500 & 2004 & 3.05 & 2.82 & 2.85 & 3.51 & 0.21 \\
\hline Sauk River near St. Cloud, Minn. & 05270500 & 2005 & 5.49 & 5.01 & 5.07 & 7.49 & 0.44 \\
\hline Sauk River near St. Cloud, Minn. & 05270500 & 2006 & 3.74 & 3.41 & 3.48 & 2.52 & -0.29 \\
\hline Sauk River near St. Cloud, Minn. & 05270500 & 2007 & 3.34 & 3.27 & 3.27 & 6.72 & 1.04 \\
\hline Sauk River near St. Cloud, Minn. & 05270500 & 2008 & 3.66 & 3.63 & 3.67 & 3.09 & -0.15 \\
\hline Sauk River near St. Cloud, Minn. & 05270500 & 2009 & 5.80 & 5.57 & 5.34 & 7.62 & 0.37 \\
\hline Sauk River near St. Cloud, Minn. & 05270500 & 2010 & 7.00 & 6.33 & 6.42 & 8.44 & 0.28 \\
\hline Elk River near Big Lake, Minn. & 05275000 & 1996 & 6.02 & 5.99 & 5.87 & 2.95 & -0.51 \\
\hline Elk River near Big Lake, Minn. & 05275000 & 1997 & 6.69 & 6.09 & 6.16 & 7.05 & 0.12 \\
\hline Elk River near Big Lake, Minn. & 05275000 & 1998 & 4.36 & 4.18 & 4.15 & 3.37 & -0.20 \\
\hline Elk River near Big Lake, Minn. & 05275000 & 1999 & 3.80 & 3.85 & 3.78 & 3.11 & -0.18 \\
\hline Elk River near Big Lake, Minn. & 05275000 & 2000 & 2.32 & 2.27 & 2.29 & 1.44 & -0.37 \\
\hline Elk River near Big Lake, Minn. & 05275000 & 2001 & 6.31 & 5.69 & 5.89 & 9.59 & 0.61 \\
\hline Elk River near Big Lake, Minn. & 05275000 & 2002 & 9.93 & 9.31 & 9.12 & 12.62 & 0.34 \\
\hline Elk River near Big Lake, Minn. & 05275000 & 2003 & 6.13 & 5.80 & 5.78 & 3.14 & -0.47 \\
\hline Elk River near Big Lake, Minn. & 05275000 & 2004 & 5.37 & 5.40 & 5.36 & 6.48 & 0.20 \\
\hline Elk River near Big Lake, Minn. & 05275000 & 2005 & 7.50 & 7.10 & 7.11 & 9.25 & 0.28 \\
\hline Elk River near Big Lake, Minn. & 05275000 & 2006 & 5.00 & 4.78 & 4.77 & 2.99 & -0.38 \\
\hline Elk River near Big Lake, Minn. & 05275000 & 2007 & 4.11 & 4.16 & 4.14 & 8.66 & 1.09 \\
\hline Elk River near Big Lake, Minn. & 05275000 & 2008 & 4.96 & 4.87 & 4.91 & 5.65 & 0.15 \\
\hline Elk River near Big Lake, Minn. & 05275000 & 2009 & 4.89 & 4.57 & 4.60 & 7.79 & 0.66 \\
\hline Elk River near Big Lake, Minn. & 05275000 & 2010 & 7.82 & 7.52 & 7.50 & 9.18 & 0.21 \\
\hline
\end{tabular}


Table 2-1. Annual mean base-flow estimates rates from 1996-2010 using three hydrograph separation techniques for the 35 streamgages used in model calibration analysis in comparison to the estimated annual potential recharge rates for the same period from the Soil-Water-Balance (SWB) model.-Continued

\begin{tabular}{|c|c|c|c|c|c|c|c|}
\hline \multirow[b]{2}{*}{ USGS streamgage name or statistic } & \multirow{2}{*}{$\begin{array}{c}\text { USGS } \\
\text { streamgage } \\
\text { number }\end{array}$} & \multirow[b]{2}{*}{ Year } & \multicolumn{3}{|c|}{ Base-flow estimate (in/yr) } & \multirow{2}{*}{$\begin{array}{c}\text { Potential recharge rate } \\
\text { from SWB model } \\
\text { (in/yr) }\end{array}$} & \multirow[b]{2}{*}{ Relative error ${ }^{c}$} \\
\hline & & & $\begin{array}{l}\text { PART } \\
\text { (in/yr) }\end{array}$ & $\begin{array}{l}\text { HYSEP fixed- } \\
\text { interval method }\end{array}$ & $\begin{array}{l}\text { HYSEP sliding } \\
\text { method }^{b}\end{array}$ & & \\
\hline Rum River near St. Francis, Minn. & 05286000 & 1996 & 6.18 & 6.12 & 6.19 & 2.88 & -0.53 \\
\hline Rum River near St. Francis, Minn. & 05286000 & 1997 & 5.66 & 5.42 & 5.21 & 6.91 & 0.27 \\
\hline Rum River near St. Francis, Minn. & 05286000 & 1998 & 3.40 & 3.30 & 3.25 & 3.80 & 0.15 \\
\hline Rum River near St. Francis, Minn. & 05286000 & 1999 & 4.32 & 3.86 & 3.92 & 3.95 & -0.02 \\
\hline Rum River near St. Francis, Minn. & 05286000 & 2000 & 2.61 & 2.43 & 2.42 & 2.21 & -0.11 \\
\hline Rum River near St. Francis, Minn. & 05286000 & 2001 & 7.26 & 6.65 & 6.69 & 10.30 & 0.50 \\
\hline Rum River near St. Francis, Minn. & 05286000 & 2002 & 9.43 & 8.75 & 8.84 & 10.25 & 0.14 \\
\hline Rum River near St. Francis, Minn. & 05286000 & 2003 & 7.17 & 6.90 & 6.82 & 3.43 & -0.51 \\
\hline Rum River near St. Francis, Minn. & 05286000 & 2004 & 5.22 & 5.31 & 5.25 & 6.10 & 0.16 \\
\hline Rum River near St. Francis, Minn. & 05286000 & 2005 & 7.53 & 7.60 & 7.43 & 7.89 & 0.05 \\
\hline Rum River near St. Francis, Minn. & 05286000 & 2006 & 5.12 & 4.78 & 4.77 & 2.68 & -0.45 \\
\hline Rum River near St. Francis, Minn. & 05286000 & 2007 & 3.70 & 3.60 & 3.58 & 8.40 & 1.32 \\
\hline Rum River near St. Francis, Minn. & 05286000 & 2008 & 5.03 & 5.36 & 5.09 & 6.36 & 0.23 \\
\hline Rum River near St. Francis, Minn. & 05286000 & 2009 & 4.43 & 4.00 & 4.07 & 8.04 & 0.93 \\
\hline Rum River near St. Francis, Minn. & 05286000 & 2010 & 6.27 & 5.61 & 5.70 & 9.19 & 0.57 \\
\hline Elk Creek near Champlin, Minn. & 05287890 & 1996 & 5.27 & 4.88 & 5.00 & 1.82 & -0.64 \\
\hline Elk Creek near Champlin, Minn. & 05287890 & 1997 & 5.17 & 4.90 & 4.77 & 6.47 & 0.31 \\
\hline Elk Creek near Champlin, Minn. & 05287890 & 1998 & 3.05 & 3.05 & 2.99 & 2.46 & -0.19 \\
\hline Elk Creek near Champlin, Minn. & 05287890 & 1999 & 5.33 & 5.10 & 5.02 & 1.85 & -0.64 \\
\hline Elk Creek near Champlin, Minn. & 05287890 & 2000 & 1.43 & 1.38 & 1.35 & 0.05 & -0.96 \\
\hline Elk Creek near Champlin, Minn. & 05287890 & 2001 & 7.37 & 7.58 & 7.24 & 6.76 & -0.09 \\
\hline Elk Creek near Champlin, Minn. & 05287890 & 2002 & 12.45 & 11.69 & 11.81 & 13.09 & 0.09 \\
\hline Elk Creek near Champlin, Minn. & 05287890 & 2003 & 5.04 & 5.32 & 5.11 & 2.37 & -0.54 \\
\hline Elk Creek near Champlin, Minn. & 05287890 & 2004 & 5.12 & 4.80 & 4.77 & 5.64 & 0.15 \\
\hline Elk Creek near Champlin, Minn. & 05287890 & 2005 & 4.54 & 4.18 & 4.27 & 7.66 & 0.77 \\
\hline Elk Creek near Champlin, Minn. & 05287890 & 2006 & 3.85 & 3.70 & 3.74 & 3.96 & 0.05 \\
\hline Elk Creek near Champlin, Minn. & 05287890 & 2007 & 4.33 & 4.30 & 4.29 & 7.56 & 0.76 \\
\hline Elk Creek near Champlin, Minn. & 05287890 & 2008 & 3.61 & 3.62 & 3.66 & 1.95 & -0.46 \\
\hline Elk Creek near Champlin, Minn. & 05287890 & 2009 & 1.91 & 1.92 & 1.93 & 4.42 & 1.30 \\
\hline Elk Creek near Champlin, Minn. & 05287890 & 2010 & 4.94 & 4.79 & 4.89 & 6.00 & 0.23 \\
\hline
\end{tabular}


Table 2-1. Annual mean base-flow estimates rates from 1996-2010 using three hydrograph separation techniques for the 35 streamgages used in model calibration analysis in comparison to the estimated annual potential recharge rates for the same period from the Soil-Water-Balance (SWB) model.-Continued

\begin{tabular}{|c|c|c|c|c|c|c|c|}
\hline \multirow[b]{2}{*}{ USGS streamgage name or statistic } & \multirow{2}{*}{$\begin{array}{c}\text { USGS } \\
\text { streamgage } \\
\text { number }\end{array}$} & \multirow[b]{2}{*}{ Year } & \multicolumn{3}{|c|}{ Base-flow estimate (in/yr) } & \multirow{2}{*}{$\begin{array}{c}\text { Potential recharge rate } \\
\text { from SWB model } \\
\text { (in/yr) }\end{array}$} & \multirow[b]{2}{*}{ Relative error ${ }^{c}$} \\
\hline & & & $\begin{array}{l}\text { PART }^{a} \\
\text { (in/yr) }\end{array}$ & $\begin{array}{l}\text { HYSEP fixed- } \\
\text { interval method }\end{array}$ & $\begin{array}{l}\text { HYSEP sliding } \\
\text { method }^{\mathrm{b}}\end{array}$ & & \\
\hline Pomme de Terre River at Appleton, Minn. & 05294000 & 1996 & 3.40 & 3.26 & 3.24 & 2.37 & -0.28 \\
\hline Pomme de Terre River at Appleton, Minn. & 05294000 & 1997 & 4.99 & 4.89 & 4.73 & 5.77 & 0.19 \\
\hline Pomme de Terre River at Appleton, Minn. & 05294000 & 1998 & 2.48 & 2.49 & 2.47 & 2.79 & 0.13 \\
\hline Pomme de Terre River at Appleton, Minn. & 05294000 & 2004 & 1.99 & 2.02 & 2.00 & 2.73 & 0.36 \\
\hline Pomme de Terre River at Appleton, Minn. & 05294000 & 2005 & 3.36 & 3.33 & 3.29 & 2.95 & -0.11 \\
\hline Pomme de Terre River at Appleton, Minn. & 05294000 & 2006 & 3.03 & 2.91 & 2.95 & 1.87 & -0.37 \\
\hline Pomme de Terre River at Appleton, Minn. & 05294000 & 2007 & 2.97 & 2.86 & 2.89 & 5.03 & 0.73 \\
\hline Pomme de Terre River at Appleton, Minn. & 05294000 & 2008 & 2.31 & 2.58 & 2.52 & 2.56 & 0.04 \\
\hline Pomme de Terre River at Appleton, Minn. & 05294000 & 2009 & 3.95 & 3.96 & 4.01 & 6.60 & 0.66 \\
\hline Pomme de Terre River at Appleton, Minn. & 05294000 & 2010 & 5.12 & 5.02 & 5.00 & 6.66 & 0.32 \\
\hline Chippewa River near Milan, Minn. & 05304500 & 1996 & 4.66 & 4.51 & 4.51 & 2.29 & -0.50 \\
\hline Chippewa River near Milan, Minn. & 05304500 & 1997 & 5.97 & 5.87 & 5.53 & 5.50 & -0.05 \\
\hline Chippewa River near Milan, Minn. & 05304500 & 1998 & 3.72 & 3.48 & 3.45 & 2.69 & -0.24 \\
\hline Chippewa River near Milan, Minn. & 05304500 & 1999 & 3.93 & 3.74 & 3.80 & 1.20 & -0.69 \\
\hline Chippewa River near Milan, Minn. & 05304500 & 2000 & 1.53 & 1.49 & 1.49 & 0.93 & -0.38 \\
\hline Chippewa River near Milan, Minn. & 05304500 & 2001 & 5.68 & 5.22 & 5.06 & 5.42 & 0.02 \\
\hline Chippewa River near Milan, Minn. & 05304500 & 2002 & 2.64 & 2.54 & 2.54 & 2.28 & -0.12 \\
\hline Chippewa River near Milan, Minn. & 05304500 & 2003 & 2.02 & 1.99 & 1.97 & 1.44 & -0.28 \\
\hline Chippewa River near Milan, Minn. & 05304500 & 2004 & 1.90 & 1.77 & 1.80 & 2.69 & 0.48 \\
\hline Chippewa River near Milan, Minn. & 05304500 & 2005 & 4.37 & 4.19 & 4.11 & 5.06 & 0.20 \\
\hline Chippewa River near Milan, Minn. & 05304500 & 2006 & 3.53 & 3.39 & 3.37 & 2.14 & -0.38 \\
\hline Chippewa River near Milan, Minn. & 05304500 & 2007 & 2.37 & 2.17 & 2.20 & 5.37 & 1.39 \\
\hline Chippewa River near Milan, Minn. & 05304500 & 2008 & 1.97 & 1.88 & 1.86 & 2.44 & 0.28 \\
\hline Chippewa River near Milan, Minn. & 05304500 & 2009 & 3.46 & 3.11 & 3.11 & 6.78 & 1.10 \\
\hline Chippewa River near Milan, Minn. & 05304500 & 2010 & 5.31 & 4.83 & 4.98 & 8.05 & 0.60 \\
\hline Yellow Medicine River near Granite Falls, Minn. & 05313500 & 1996 & 3.22 & 3.01 & 3.00 & 1.20 & -0.61 \\
\hline Yellow Medicine River near Granite Falls, Minn. & 05313500 & 1997 & 6.29 & 5.90 & 5.45 & 5.27 & -0.10 \\
\hline Yellow Medicine River near Granite Falls, Minn. & 05313500 & 1998 & 2.26 & 2.63 & 2.52 & 3.55 & 0.44 \\
\hline Yellow Medicine River near Granite Falls, Minn. & 05313500 & 1999 & 2.14 & 1.95 & 1.95 & 0.36 & -0.82 \\
\hline
\end{tabular}


Table 2-1. Annual mean base-flow estimates rates from 1996-2010 using three hydrograph separation techniques for the 35 streamgages used in model calibration analysis in comparison to the estimated annual potential recharge rates for the same period from the Soil-Water-Balance (SWB) model.-Continued

\begin{tabular}{|c|c|c|c|c|c|c|c|}
\hline \multirow[b]{2}{*}{ USGS streamgage name or statistic } & \multirow{2}{*}{$\begin{array}{c}\text { USGS } \\
\text { streamgage } \\
\text { number }\end{array}$} & \multirow[b]{2}{*}{ Year } & \multicolumn{3}{|c|}{ Base-flow estimate (in/yr) } & \multirow{2}{*}{$\begin{array}{c}\text { Potential recharge rate } \\
\text { from SWB model } \\
\text { (in/yr) }\end{array}$} & \multirow[b]{2}{*}{ Relative error ${ }^{c}$} \\
\hline & & & $\begin{array}{l}\text { PART }^{a} \\
\text { (in/yr) }\end{array}$ & $\begin{array}{l}\text { HYSEP fixed- } \\
\text { interval method }\end{array}$ & $\begin{array}{l}\text { HYSEP sliding } \\
\text { method }^{b}\end{array}$ & & \\
\hline Yellow Medicine River near Granite Falls, Minn. & 05313500 & 2000 & 0.49 & 0.43 & 0.45 & 0.23 & -0.49 \\
\hline Yellow Medicine River near Granite Falls, Minn. & 05313500 & 2001 & 3.31 & 3.78 & 3.93 & 6.05 & 0.65 \\
\hline Yellow Medicine River near Granite Falls, Minn. & 05313500 & 2002 & 2.27 & 2.14 & 2.11 & 1.35 & -0.38 \\
\hline Yellow Medicine River near Granite Falls, Minn. & 05313500 & 2003 & 1.02 & 0.96 & 0.90 & 0.59 & -0.39 \\
\hline Yellow Medicine River near Granite Falls, Minn. & 05313500 & 2004 & 1.46 & 1.40 & 1.37 & 3.33 & 1.36 \\
\hline Yellow Medicine River near Granite Falls, Minn. & 05313500 & 2005 & 2.21 & 1.89 & 1.95 & 2.59 & 0.28 \\
\hline Yellow Medicine River near Granite Falls, Minn. & 05313500 & 2006 & 3.51 & 3.32 & 3.26 & 2.37 & -0.30 \\
\hline Yellow Medicine River near Granite Falls, Minn. & 05313500 & 2007 & 2.79 & 2.45 & 2.48 & 4.62 & 0.79 \\
\hline Yellow Medicine River near Granite Falls, Minn. & 05313500 & 2008 & 2.17 & 2.15 & 2.09 & 1.38 & -0.35 \\
\hline Yellow Medicine River near Granite Falls, Minn. & 05313500 & 2009 & 1.46 & 1.51 & 1.44 & 4.89 & 2.32 \\
\hline Yellow Medicine River near Granite Falls, Minn. & 05313500 & 2010 & 9.98 & 9.81 & 9.30 & 9.78 & 0.01 \\
\hline Redwood River near Marshall, Minn. & 05315000 & 1996 & 3.72 & 3.45 & 3.42 & 1.00 & -0.72 \\
\hline Redwood River near Marshall, Minn. & 05315000 & 1997 & 6.67 & 5.65 & 5.76 & 5.44 & -0.10 \\
\hline Redwood River near Marshall, Minn. & 05315000 & 1998 & 3.59 & 3.31 & 3.25 & 5.08 & 0.50 \\
\hline Redwood River near Marshall, Minn. & 05315000 & 1999 & 4.08 & 3.63 & 3.72 & 1.35 & -0.65 \\
\hline Redwood River near Marshall, Minn. & 05315000 & 2000 & 1.44 & 1.26 & 1.24 & 0.67 & -0.49 \\
\hline Redwood River near Marshall, Minn. & 05315000 & 2001 & 5.96 & 5.46 & 5.41 & 6.45 & 0.15 \\
\hline Redwood River near Marshall, Minn. & 05315000 & 2002 & 3.11 & 2.81 & 2.82 & 1.80 & -0.38 \\
\hline Redwood River near Marshall, Minn. & 05315000 & 2003 & 1.62 & 1.39 & 1.51 & 1.18 & -0.21 \\
\hline Redwood River near Marshall, Minn. & 05315000 & 2004 & 2.13 & 1.89 & 1.82 & 4.12 & 1.12 \\
\hline Redwood River near Marshall, Minn. & 05315000 & 2005 & 2.15 & 1.96 & 1.96 & 2.95 & 0.46 \\
\hline Redwood River near Marshall, Minn. & 05315000 & 2006 & 4.03 & 3.67 & 3.69 & 2.99 & -0.21 \\
\hline Redwood River near Marshall, Minn. & 05315000 & 2007 & 4.29 & 3.97 & 3.92 & 5.49 & 0.35 \\
\hline Redwood River near Marshall, Minn. & 05315000 & 2008 & 3.12 & 2.79 & 2.81 & 1.86 & -0.36 \\
\hline Redwood River near Marshall, Minn. & 05315000 & 2009 & 1.60 & 1.48 & 1.46 & 4.06 & 1.68 \\
\hline Redwood River near Marshall, Minn. & 05315000 & 2010 & 11.56 & 9.56 & 9.88 & 10.62 & 0.03 \\
\hline Cottonwood River near New Ulm, Minn. & 05317000 & 1996 & 4.26 & 3.50 & 3.61 & 1.73 & -0.54 \\
\hline Cottonwood River near New Ulm, Minn. & 05317000 & 1997 & 6.75 & 6.09 & 6.47 & 5.08 & -0.21 \\
\hline Cottonwood River near New Ulm, Minn. & 05317000 & 1998 & 3.71 & 3.39 & 3.43 & 2.87 & -0.18 \\
\hline
\end{tabular}


Table 2-1. Annual mean base-flow estimates rates from 1996-2010 using three hydrograph separation techniques for the 35 streamgages used in model calibration analysis in comparison to the estimated annual potential recharge rates for the same period from the Soil-Water-Balance (SWB) model.-Continued

\begin{tabular}{|c|c|c|c|c|c|c|c|}
\hline \multirow[b]{2}{*}{ USGS streamgage name or statistic } & \multirow{2}{*}{$\begin{array}{c}\text { USGS } \\
\text { streamgage } \\
\text { number }\end{array}$} & \multirow[b]{2}{*}{ Year } & \multicolumn{3}{|c|}{ Base-flow estimate (in/yr) } & \multirow{2}{*}{$\begin{array}{c}\text { Potential recharge rate } \\
\text { from SWB model } \\
\text { (in/yr) }\end{array}$} & \multirow[b]{2}{*}{ Relative error ${ }^{c}$} \\
\hline & & & $\begin{array}{l}\text { PART }^{a} \\
\text { (in/yr) }\end{array}$ & $\begin{array}{l}\text { HYSEP fixed- } \\
\text { interval method }\end{array}$ & $\begin{array}{l}\text { HYSEP sliding } \\
\text { method }^{b}\end{array}$ & & \\
\hline Cottonwood River near New Ulm, Minn. & 05317000 & 1999 & 3.22 & 2.89 & 2.90 & 0.89 & -0.71 \\
\hline Cottonwood River near New Ulm, Minn. & 05317000 & 2000 & 1.21 & 0.99 & 1.01 & 0.52 & -0.52 \\
\hline Cottonwood River near New Ulm, Minn. & 05317000 & 2001 & 6.14 & 5.40 & 5.22 & 7.62 & 0.36 \\
\hline Cottonwood River near New Ulm, Minn. & 05317000 & 2002 & 3.61 & 3.01 & 3.10 & 1.62 & -0.50 \\
\hline Cottonwood River near New Ulm, Minn. & 05317000 & 2003 & 1.94 & 1.64 & 1.65 & 0.45 & -0.74 \\
\hline Cottonwood River near New Ulm, Minn. & 05317000 & 2004 & 2.88 & 2.51 & 2.61 & 4.88 & 0.83 \\
\hline Cottonwood River near New Ulm, Minn. & 05317000 & 2005 & 3.59 & 3.33 & 3.40 & 5.25 & 0.53 \\
\hline Cottonwood River near New Ulm, Minn. & 05317000 & 2006 & 5.21 & 4.56 & 4.56 & 3.08 & -0.35 \\
\hline Cottonwood River near New Ulm, Minn. & 05317000 & 2007 & 3.73 & 2.96 & 3.24 & 6.06 & 0.83 \\
\hline Cottonwood River near New Ulm, Minn. & 05317000 & 2008 & 3.03 & 2.89 & 2.97 & 1.78 & -0.40 \\
\hline Cottonwood River near New Ulm, Minn. & 05317000 & 2009 & 1.72 & 1.66 & 1.62 & 3.99 & 1.40 \\
\hline Cottonwood River near New Ulm, Minn. & 05317000 & 2010 & 9.35 & 7.93 & 8.15 & 9.45 & 0.11 \\
\hline Little Cottonwood River near Courtland, Minn. & 05317200 & 1996 & 6.72 & 7.00 & 6.75 & 2.58 & -0.62 \\
\hline Little Cottonwood River near Courtland, Minn. & 05317200 & 1997 & 6.66 & 6.82 & 6.93 & 4.65 & -0.32 \\
\hline Little Cottonwood River near Courtland, Minn. & 05317200 & 1998 & 4.02 & 4.21 & 4.13 & 2.39 & -0.42 \\
\hline Little Cottonwood River near Courtland, Minn. & 05317200 & 1999 & 3.72 & 3.57 & 3.66 & 1.08 & -0.70 \\
\hline Little Cottonwood River near Courtland, Minn. & 05317200 & 2000 & 1.81 & 1.65 & 1.71 & 0.95 & -0.45 \\
\hline Little Cottonwood River near Courtland, Minn. & 05317200 & 2001 & 8.97 & 8.51 & 8.91 & 7.48 & -0.15 \\
\hline Little Cottonwood River near Courtland, Minn. & 05317200 & 2002 & 4.20 & 4.02 & 4.00 & 2.06 & -0.49 \\
\hline Little Cottonwood River near Courtland, Minn. & 05317200 & 2003 & 2.06 & 1.98 & 2.00 & 0.14 & -0.93 \\
\hline Little Cottonwood River near Courtland, Minn. & 05317200 & 2004 & 2.40 & 2.52 & 2.44 & 4.71 & 0.92 \\
\hline Little Cottonwood River near Courtland, Minn. & 05317200 & 2005 & 4.12 & 3.83 & 3.96 & 6.06 & 0.53 \\
\hline Little Cottonwood River near Courtland, Minn. & 05317200 & 2006 & 4.92 & 5.01 & 4.94 & 4.18 & -0.16 \\
\hline Little Cottonwood River near Courtland, Minn. & 05317200 & 2007 & 5.08 & 4.85 & 4.91 & 7.00 & 0.42 \\
\hline Little Cottonwood River near Courtland, Minn. & 05317200 & 2008 & 4.22 & 4.13 & 4.21 & 2.26 & -0.46 \\
\hline Little Cottonwood River near Courtland, Minn. & 05317200 & 2009 & 2.67 & 2.77 & 2.74 & 4.55 & 0.67 \\
\hline Watonwan River near Garden City, Minn. & 05319500 & 1996 & 5.99 & 5.59 & 5.49 & 2.63 & -0.54 \\
\hline Watonwan River near Garden City, Minn. & 05319500 & 1997 & 7.46 & 7.82 & 7.61 & 3.89 & -0.49 \\
\hline Watonwan River near Garden City, Minn. & 05319500 & 1998 & 4.24 & 3.85 & 3.95 & 2.34 & -0.42 \\
\hline
\end{tabular}


Table 2-1. Annual mean base-flow estimates rates from 1996-2010 using three hydrograph separation techniques for the 35 streamgages used in model calibration analysis in comparison to the estimated annual potential recharge rates for the same period from the Soil-Water-Balance (SWB) model.-Continued

\begin{tabular}{|c|c|c|c|c|c|c|c|}
\hline \multirow[b]{2}{*}{ USGS streamgage name or statistic } & \multirow{2}{*}{$\begin{array}{c}\text { USGS } \\
\text { streamgage } \\
\text { number }\end{array}$} & \multirow[b]{2}{*}{ Year } & \multicolumn{3}{|c|}{ Base-flow estimate (in/yr) } & \multirow{2}{*}{$\begin{array}{l}\text { Potential recharge rate } \\
\text { from SWB model } \\
\text { (in/yr) }\end{array}$} & \multirow[b]{2}{*}{ Relative error $^{\mathrm{c}}$} \\
\hline & & & $\begin{array}{l}\text { PART }^{a} \\
\text { (in/yr) }\end{array}$ & $\begin{array}{l}\text { HYSEP fixed- } \\
\text { interval method }\end{array}$ & $\begin{array}{l}\text { HYSEP sliding } \\
\text { method }^{b}\end{array}$ & & \\
\hline Watonwan River near Garden City, Minn. & 05319500 & 1999 & 4.25 & 4.37 & 4.31 & 1.36 & -0.68 \\
\hline Watonwan River near Garden City, Minn. & 05319500 & 2000 & 1.29 & 1.18 & 1.15 & 0.97 & -0.20 \\
\hline Watonwan River near Garden City, Minn. & 05319500 & 2001 & 7.65 & 7.76 & 7.39 & 6.51 & -0.14 \\
\hline Watonwan River near Garden City, Minn. & 05319500 & 2002 & 2.18 & 1.99 & 2.03 & 2.31 & 0.12 \\
\hline Watonwan River near Garden City, Minn. & 05319500 & 2003 & 2.42 & 2.17 & 2.20 & 0.14 & -0.94 \\
\hline Watonwan River near Garden City, Minn. & 05319500 & 2004 & 3.61 & 3.43 & 3.36 & 4.44 & 0.28 \\
\hline Watonwan River near Garden City, Minn. & 05319500 & 2005 & 6.72 & 6.55 & 6.39 & 6.56 & 0.00 \\
\hline Watonwan River near Garden City, Minn. & 05319500 & 2006 & 5.94 & 6.19 & 6.07 & 4.68 & -0.23 \\
\hline Watonwan River near Garden City, Minn. & 05319500 & 2007 & 4.70 & 4.57 & 4.31 & 7.42 & 0.64 \\
\hline Watonwan River near Garden City, Minn. & 05319500 & 2008 & 4.42 & 3.93 & 4.20 & 2.40 & -0.43 \\
\hline Watonwan River near Garden City, Minn. & 05319500 & 2009 & 2.01 & 1.99 & 1.96 & 5.11 & 1.57 \\
\hline Watonwan River near Garden City, Minn. & 05319500 & 2010 & 10.91 & 10.00 & 10.10 & 9.30 & -0.10 \\
\hline Le Sueur River near Rapidan, Minn. & 05320500 & 1996 & 5.14 & 4.08 & 4.27 & 2.63 & -0.41 \\
\hline Le Sueur River near Rapidan, Minn. & 05320500 & 1997 & 6.19 & 5.17 & 5.58 & 4.55 & -0.19 \\
\hline Le Sueur River near Rapidan, Minn. & 05320500 & 1998 & 5.90 & 5.37 & 5.21 & 4.12 & -0.25 \\
\hline Le Sueur River near Rapidan, Minn. & 05320500 & 1999 & 8.06 & 6.54 & 7.40 & 6.24 & -0.15 \\
\hline Le Sueur River near Rapidan, Minn. & 05320500 & 2000 & 4.34 & 4.45 & 4.00 & 3.47 & -0.19 \\
\hline Le Sueur River near Rapidan, Minn. & 05320500 & 2001 & 8.58 & 8.17 & 7.84 & 7.68 & -0.06 \\
\hline Le Sueur River near Rapidan, Minn. & 05320500 & 2002 & 3.90 & 3.19 & 3.40 & 2.84 & -0.19 \\
\hline Le Sueur River near Rapidan, Minn. & 05320500 & 2003 & 3.23 & 2.71 & 2.75 & 0.61 & -0.79 \\
\hline Le Sueur River near Rapidan, Minn. & 05320500 & 2004 & 5.72 & 3.90 & 4.68 & 7.08 & 0.48 \\
\hline Le Sueur River near Rapidan, Minn. & 05320500 & 2005 & 6.96 & 5.98 & 5.71 & 5.39 & -0.13 \\
\hline Le Sueur River near Rapidan, Minn. & 05320500 & 2006 & 6.08 & 6.17 & 5.98 & 5.19 & -0.15 \\
\hline Le Sueur River near Rapidan, Minn. & 05320500 & 2007 & 7.56 & 6.68 & 6.75 & 9.26 & 0.32 \\
\hline Le Sueur River near Rapidan, Minn. & 05320500 & 2008 & 4.66 & 4.17 & 4.17 & 2.89 & -0.33 \\
\hline Le Sueur River near Rapidan, Minn. & 05320500 & 2009 & 2.64 & 2.17 & 2.20 & 3.75 & 0.60 \\
\hline Le Sueur River near Rapidan, Minn. & 05320500 & 2010 & 11.67 & 10.14 & 9.92 & 9.10 & -0.14 \\
\hline High Island Creek near Henderson, Minn. & 05327000 & 1996 & 3.61 & 3.61 & 3.63 & 2.58 & -0.29 \\
\hline High Island Creek near Henderson, Minn. & 05327000 & 1997 & 7.97 & 7.56 & 7.46 & 7.27 & -0.05 \\
\hline
\end{tabular}


Table 2-1. Annual mean base-flow estimates rates from 1996-2010 using three hydrograph separation techniques for the 35 streamgages used in model calibration analysis in comparison to the estimated annual potential recharge rates for the same period from the Soil-Water-Balance (SWB) model.-Continued

\begin{tabular}{|c|c|c|c|c|c|c|c|}
\hline \multirow[b]{2}{*}{ USGS streamgage name or statistic } & \multirow{2}{*}{$\begin{array}{c}\text { USGS } \\
\text { streamgage } \\
\text { number }\end{array}$} & \multirow[b]{2}{*}{ Year } & \multicolumn{3}{|c|}{ Base-flow estimate (in/yr) } & \multirow{2}{*}{$\begin{array}{c}\text { Potential recharge rate } \\
\text { from SWB model } \\
\text { (in/yr) }\end{array}$} & \multirow[b]{2}{*}{ Relative error ${ }^{c}$} \\
\hline & & & $\begin{array}{l}\text { PART }^{a} \\
\text { (in/yr) }\end{array}$ & $\begin{array}{l}\text { HYSEP fixed- } \\
\text { interval method }\end{array}$ & $\begin{array}{l}\text { HYSEP sliding } \\
\text { method }^{\mathrm{b}}\end{array}$ & & \\
\hline High Island Creek near Henderson, Minn. & 05327000 & 1998 & 4.82 & 5.12 & 4.84 & 1.81 & -0.63 \\
\hline High Island Creek near Henderson, Minn. & 05327000 & 1999 & 3.74 & 3.85 & 3.87 & 1.38 & -0.64 \\
\hline High Island Creek near Henderson, Minn. & 05327000 & 2000 & 0.68 & 0.70 & 0.69 & 0.07 & -0.90 \\
\hline High Island Creek near Henderson, Minn. & 05327000 & 2001 & 6.24 & 6.72 & 6.58 & 7.55 & 0.16 \\
\hline High Island Creek near Henderson, Minn. & 05327000 & 2002 & 3.75 & 3.66 & 3.59 & 4.67 & 0.27 \\
\hline High Island Creek near Henderson, Minn. & 05327000 & 2003 & 2.16 & 2.17 & 2.19 & 0.59 & -0.73 \\
\hline High Island Creek near Henderson, Minn. & 05327000 & 2004 & 4.29 & 4.78 & 4.74 & 4.85 & 0.05 \\
\hline High Island Creek near Henderson, Minn. & 05327000 & 2005 & 4.86 & 4.92 & 5.06 & 3.93 & -0.21 \\
\hline High Island Creek near Henderson, Minn. & 05327000 & 2006 & 4.47 & 4.28 & 4.28 & 2.83 & -0.35 \\
\hline High Island Creek near Henderson, Minn. & 05327000 & 2007 & 3.15 & 3.02 & 3.01 & 6.46 & 1.11 \\
\hline High Island Creek near Henderson, Minn. & 05327000 & 2008 & 2.70 & 2.61 & 2.70 & 1.34 & -0.50 \\
\hline High Island Creek near Henderson, Minn. & 05327000 & 2009 & 3.35 & 3.82 & 3.84 & 6.73 & 0.83 \\
\hline High Island Creek near Henderson, Minn. & 05327000 & 2010 & 10.29 & 9.85 & 9.85 & 7.62 & -0.24 \\
\hline Kettle River below Sandstone, Minn. & 05336700 & 1996 & 9.81 & 9.40 & 9.52 & 6.07 & -0.37 \\
\hline Kettle River below Sandstone, Minn. & 05336700 & 1997 & 8.39 & 7.63 & 7.83 & 7.98 & 0.00 \\
\hline Kettle River below Sandstone, Minn. & 05336700 & 1998 & 5.64 & 5.43 & 5.41 & 6.49 & 0.18 \\
\hline Kettle River below Sandstone, Minn. & 05336700 & 1999 & 9.03 & 8.34 & 8.35 & 6.33 & -0.26 \\
\hline Kettle River below Sandstone, Minn. & 05336700 & 2000 & 6.59 & 5.66 & 5.71 & 3.95 & -0.34 \\
\hline Kettle River below Sandstone, Minn. & 05336700 & 2001 & 8.80 & 9.32 & 8.80 & 10.93 & 0.22 \\
\hline Kettle River below Sandstone, Minn. & 05336700 & 2002 & 8.39 & 7.21 & 7.50 & 8.89 & 0.15 \\
\hline Kettle River below Sandstone, Minn. & 05336700 & 2003 & 6.94 & 6.03 & 6.39 & 3.54 & -0.45 \\
\hline Kettle River below Sandstone, Minn. & 05336700 & 2004 & 7.15 & 6.20 & 6.31 & 5.55 & -0.15 \\
\hline Kettle River below Sandstone, Minn. & 05336700 & 2005 & 8.30 & 7.23 & 7.57 & 6.30 & -0.18 \\
\hline Kettle River below Sandstone, Minn. & 05336700 & 2006 & 5.19 & 4.62 & 4.66 & 2.61 & -0.46 \\
\hline Kettle River below Sandstone, Minn. & 05336700 & 2007 & 4.66 & 4.48 & 4.38 & 8.51 & 0.89 \\
\hline Kettle River below Sandstone, Minn. & 05336700 & 2008 & 8.43 & 7.76 & 7.90 & 7.68 & -0.04 \\
\hline Kettle River below Sandstone, Minn. & 05336700 & 2009 & 6.52 & 5.73 & 6.00 & 8.50 & 0.40 \\
\hline Kettle River below Sandstone, Minn. & 05336700 & 2010 & 8.31 & 7.28 & 7.30 & 10.52 & 0.38 \\
\hline
\end{tabular}


Table 2-1. Annual mean base-flow estimates rates from 1996-2010 using three hydrograph separation techniques for the 35 streamgages used in model calibration analysis in comparison to the estimated annual potential recharge rates for the same period from the Soil-Water-Balance (SWB) model.-Continued

\begin{tabular}{|c|c|c|c|c|c|c|c|}
\hline \multirow[b]{2}{*}{ USGS streamgage name or statistic } & \multirow{2}{*}{$\begin{array}{c}\text { USGS } \\
\text { streamgage } \\
\text { number }\end{array}$} & \multirow[b]{2}{*}{ Year } & \multicolumn{3}{|c|}{ Base-flow estimate (in/yr) } & \multirow{2}{*}{$\begin{array}{l}\text { Potential recharge rate } \\
\text { from SWB model } \\
\text { (in/yr) }\end{array}$} & \multirow[b]{2}{*}{ Relative error } \\
\hline & & & $\begin{array}{l}\text { PARTa } \\
\text { (in/yr) }\end{array}$ & $\begin{array}{l}\text { HYSEP fixed- } \\
\text { interval method }\end{array}$ & $\begin{array}{l}\text { HYSEP sliding } \\
\text { method }^{\mathrm{b}}\end{array}$ & & \\
\hline Snake River near Pine City, Minn. & 05338500 & 1996 & 7.38 & 7.48 & 7.48 & 2.65 & -0.64 \\
\hline Snake River near Pine City, Minn. & 05338500 & 1997 & 5.92 & 5.70 & 5.88 & 6.04 & 0.03 \\
\hline Snake River near Pine City, Minn. & 05338500 & 1998 & 3.48 & 3.39 & 3.40 & 3.89 & 0.14 \\
\hline Snake River near Pine City, Minn. & 05338500 & 1999 & 5.56 & 5.36 & 5.35 & 3.78 & -0.30 \\
\hline Snake River near Pine City, Minn. & 05338500 & 2000 & 4.05 & 4.09 & 3.92 & 2.14 & -0.47 \\
\hline Snake River near Pine City, Minn. & 05338500 & 2001 & 9.58 & 9.68 & 8.99 & 9.69 & 0.03 \\
\hline Snake River near Pine City, Minn. & 05338500 & 2002 & 9.55 & 8.87 & 9.12 & 8.47 & -0.08 \\
\hline Snake River near Pine City, Minn. & 05338500 & 2003 & 7.02 & 6.48 & 6.70 & 2.79 & -0.59 \\
\hline Snake River near Pine City, Minn. & 05338500 & 2004 & 5.84 & 5.89 & 5.93 & 4.15 & -0.29 \\
\hline Snake River near Pine City, Minn. & 05338500 & 2005 & 8.42 & 7.97 & 8.27 & 6.39 & -0.22 \\
\hline Snake River near Pine City, Minn. & 05338500 & 2006 & 4.37 & 4.23 & 4.16 & 1.94 & -0.54 \\
\hline Snake River near Pine City, Minn. & 05338500 & 2007 & 4.88 & 5.18 & 4.94 & 7.42 & 0.48 \\
\hline Snake River near Pine City, Minn. & 05338500 & 2008 & 8.00 & 8.56 & 8.53 & 6.77 & -0.19 \\
\hline Snake River near Pine City, Minn. & 05338500 & 2009 & 6.11 & 5.62 & 5.93 & 7.35 & 0.25 \\
\hline Snake River near Pine City, Minn. & 05338500 & 2010 & 9.44 & 8.50 & 8.68 & 8.18 & -0.08 \\
\hline Vermillion River near Empire, Minn. & 05345000 & 1996 & 6.76 & 6.60 & 6.59 & 6.29 & -0.05 \\
\hline Vermillion River near Empire, Minn. & 05345000 & 1997 & 10.59 & 10.20 & 10.33 & 11.30 & 0.09 \\
\hline Vermillion River near Empire, Minn. & 05345000 & 1998 & 12.24 & 12.12 & 11.88 & 9.30 & -0.23 \\
\hline Vermillion River near Empire, Minn. & 05345000 & 1999 & 8.60 & 8.27 & 8.23 & 6.10 & -0.27 \\
\hline Vermillion River near Empire, Minn. & 05345000 & 2000 & 6.20 & 5.90 & 6.01 & 3.84 & -0.36 \\
\hline Vermillion River near Empire, Minn. & 05345000 & 2001 & 7.46 & 7.20 & 7.28 & 8.22 & 0.12 \\
\hline Vermillion River near Empire, Minn. & 05345000 & 2002 & 9.69 & 8.87 & 9.16 & 11.09 & 0.20 \\
\hline Vermillion River near Empire, Minn. & 05345000 & 2003 & 6.07 & 5.85 & 5.85 & 2.35 & -0.60 \\
\hline Vermillion River near Empire, Minn. & 05345000 & 2004 & 5.99 & 5.90 & 5.83 & 6.42 & 0.09 \\
\hline Vermillion River near Empire, Minn. & 05345000 & 2005 & 6.78 & 6.45 & 6.54 & 7.20 & 0.09 \\
\hline Vermillion River near Empire, Minn. & 05345000 & 2006 & 5.75 & 5.67 & 5.64 & 5.39 & -0.05 \\
\hline Vermillion River near Empire, Minn. & 05345000 & 2007 & 5.74 & 5.68 & 5.62 & 9.59 & 0.69 \\
\hline Vermillion River near Empire, Minn. & 05345000 & 2008 & 4.89 & 4.64 & 4.69 & 4.22 & -0.11 \\
\hline Vermillion River near Empire, Minn. & 05345000 & 2009 & 3.00 & 2.93 & 2.91 & 5.61 & 0.90 \\
\hline Vermillion River near Empire, Minn. & 05345000 & 2010 & 7.56 & 7.26 & 7.43 & 8.67 & 0.17 \\
\hline
\end{tabular}


Table 2-1. Annual mean base-flow estimates rates from 1996-2010 using three hydrograph separation techniques for the 35 streamgages used in model calibration analysis in comparison to the estimated annual potential recharge rates for the same period from the Soil-Water-Balance (SWB) model.-Continued

\begin{tabular}{|c|c|c|c|c|c|c|c|}
\hline \multirow[b]{2}{*}{ USGS streamgage name or statistic } & \multirow{2}{*}{$\begin{array}{c}\text { USGS } \\
\text { streamgage } \\
\text { number }\end{array}$} & \multirow[b]{2}{*}{ Year } & \multicolumn{3}{|c|}{ Base-flow estimate (in/yr) } & \multirow{2}{*}{$\begin{array}{l}\text { Potential recharge rate } \\
\text { from SWB model } \\
\text { (in/yr) }\end{array}$} & \multirow[b]{2}{*}{ Relative error ${ }^{c}$} \\
\hline & & & $\begin{array}{l}\text { PART }^{a} \\
\text { (in/yr) }\end{array}$ & $\begin{array}{l}\text { HYSEP fixed- } \\
\text { interval method }\end{array}$ & $\begin{array}{l}\text { HYSEP sliding } \\
\text { method }^{b}\end{array}$ & & \\
\hline Cannon River at Welch, Minn. & 05355200 & 1996 & 5.79 & 5.32 & 5.38 & 4.17 & -0.24 \\
\hline Cannon River at Welch, Minn. & 05355200 & 1997 & 8.99 & 8.28 & 8.52 & 7.53 & -0.12 \\
\hline Cannon River at Welch, Minn. & 05355200 & 1998 & 9.11 & 8.01 & 8.26 & 6.09 & -0.28 \\
\hline Cannon River at Welch, Minn. & 05355200 & 1999 & 8.53 & 7.76 & 7.81 & 7.84 & -0.02 \\
\hline Cannon River at Welch, Minn. & 05355200 & 2000 & 6.04 & 5.68 & 5.46 & 3.90 & -0.32 \\
\hline Cannon River at Welch, Minn. & 05355200 & 2001 & 8.77 & 8.43 & 8.46 & 8.41 & -0.02 \\
\hline Cannon River at Welch, Minn. & 05355200 & 2002 & 6.37 & 5.81 & 5.84 & 6.23 & 0.04 \\
\hline Cannon River at Welch, Minn. & 05355200 & 2003 & 4.53 & 4.12 & 4.12 & 1.34 & -0.68 \\
\hline Cannon River at Welch, Minn. & 05355200 & 2004 & 7.10 & 6.31 & 6.28 & 7.69 & 0.17 \\
\hline Cannon River at Welch, Minn. & 05355200 & 2005 & 6.77 & 5.99 & 6.11 & 5.45 & -0.13 \\
\hline Cannon River at Welch, Minn. & 05355200 & 2006 & 6.10 & 5.58 & 5.73 & 5.11 & -0.12 \\
\hline Cannon River at Welch, Minn. & 05355200 & 2007 & 7.80 & 6.72 & 6.66 & 10.53 & 0.49 \\
\hline Cannon River at Welch, Minn. & 05355200 & 2008 & 5.88 & 5.47 & 5.51 & 3.60 & -0.36 \\
\hline Cannon River at Welch, Minn. & 05355200 & 2009 & 3.14 & 2.95 & 2.96 & 3.95 & 0.31 \\
\hline Cannon River at Welch, Minn. & 05355200 & 2010 & 10.21 & 8.26 & 8.55 & 8.97 & -0.00 \\
\hline South Fork Zumbro River at Rochester, Minn. & 05372995 & 1996 & 5.72 & 5.00 & 5.10 & 4.72 & -0.11 \\
\hline South Fork Zumbro River at Rochester, Minn. & 05372995 & 1997 & 7.16 & 6.62 & 6.83 & 5.35 & -0.22 \\
\hline South Fork Zumbro River at Rochester, Minn. & 05372995 & 1998 & 7.24 & 6.91 & 6.81 & 5.63 & -0.19 \\
\hline South Fork Zumbro River at Rochester, Minn. & 05372995 & 1999 & 8.53 & 8.03 & 7.93 & 13.71 & 0.68 \\
\hline South Fork Zumbro River at Rochester, Minn. & 05372995 & 2000 & 6.13 & 6.03 & 5.60 & 6.00 & 0.01 \\
\hline South Fork Zumbro River at Rochester, Minn. & 05372995 & 2001 & 9.61 & 9.08 & 8.78 & 9.41 & 0.03 \\
\hline South Fork Zumbro River at Rochester, Minn. & 05372995 & 2002 & 6.23 & 5.65 & 5.74 & 3.99 & -0.32 \\
\hline South Fork Zumbro River at Rochester, Minn. & 05372995 & 2003 & 4.44 & 4.09 & 4.11 & 2.05 & -0.51 \\
\hline South Fork Zumbro River at Rochester, Minn. & 05372995 & 2004 & 6.98 & 6.60 & 6.35 & 7.27 & 0.09 \\
\hline South Fork Zumbro River at Rochester, Minn. & 05372995 & 2005 & 5.43 & 4.87 & 4.98 & 4.53 & -0.11 \\
\hline South Fork Zumbro River at Rochester, Minn. & 05372995 & 2006 & 6.64 & 6.34 & 6.23 & 5.92 & -0.08 \\
\hline South Fork Zumbro River at Rochester, Minn. & 05372995 & 2007 & 11.62 & 10.15 & 10.42 & 12.39 & 0.15 \\
\hline South Fork Zumbro River at Rochester, Minn. & 05372995 & 2008 & 8.61 & 7.86 & 7.92 & 5.11 & -0.37 \\
\hline South Fork Zumbro River at Rochester, Minn. & 05372995 & 2009 & 4.50 & 4.18 & 4.14 & 4.04 & -0.06 \\
\hline South Fork Zumbro River at Rochester, Minn. & 05372995 & 2010 & 8.73 & 8.04 & 7.68 & 8.38 & 0.03 \\
\hline
\end{tabular}


Table 2-1. Annual mean base-flow estimates rates from 1996-2010 using three hydrograph separation techniques for the 35 streamgages used in model calibration analysis in comparison to the estimated annual potential recharge rates for the same period from the Soil-Water-Balance (SWB) model.-Continued

\begin{tabular}{|c|c|c|c|c|c|c|c|}
\hline \multirow[b]{2}{*}{ USGS streamgage name or statistic } & \multirow{2}{*}{$\begin{array}{c}\text { USGS } \\
\text { streamgage } \\
\text { number }\end{array}$} & \multirow[b]{2}{*}{ Year } & \multicolumn{3}{|c|}{ Base-flow estimate (in/yr) } & \multirow{2}{*}{$\begin{array}{c}\text { Potential recharge rate } \\
\text { from SWB model } \\
\text { (in/yr) }\end{array}$} & \multirow[b]{2}{*}{ Relative error } \\
\hline & & & $\begin{array}{l}\text { PARTa } \\
\text { (in/yr) }\end{array}$ & $\begin{array}{l}\text { HYSEP fixed- } \\
\text { interval method }\end{array}$ & $\begin{array}{l}\text { HYSEP sliding } \\
\text { method }^{b}\end{array}$ & & \\
\hline Cedar River near Austin, Minn. & 05457000 & 1996 & 5.74 & 5.09 & 5.15 & 3.34 & -0.37 \\
\hline Cedar River near Austin, Minn. & 05457000 & 1997 & 7.22 & 6.89 & 6.82 & 4.49 & -0.36 \\
\hline Cedar River near Austin, Minn. & 05457000 & 1998 & 8.04 & 7.65 & 7.52 & 4.98 & -0.36 \\
\hline Cedar River near Austin, Minn. & 05457000 & 1999 & 9.51 & 9.23 & 9.08 & 11.59 & 0.25 \\
\hline Cedar River near Austin, Minn. & 05457000 & 2000 & 6.85 & 6.27 & 6.24 & 5.23 & -0.19 \\
\hline Cedar River near Austin, Minn. & 05457000 & 2001 & 9.39 & 8.95 & 9.08 & 9.50 & 0.04 \\
\hline Cedar River near Austin, Minn. & 05457000 & 2002 & 4.36 & 4.03 & 4.04 & 2.44 & -0.41 \\
\hline Cedar River near Austin, Minn. & 05457000 & 2003 & 4.34 & 4.19 & 4.35 & 1.35 & -0.68 \\
\hline Cedar River near Austin, Minn. & 05457000 & 2004 & 8.33 & 7.14 & 7.36 & 8.77 & 0.15 \\
\hline Cedar River near Austin, Minn. & 05457000 & 2005 & 6.49 & 6.19 & 5.95 & 4.82 & -0.22 \\
\hline Cedar River near Austin, Minn. & 05457000 & 2006 & 7.70 & 7.53 & 7.64 & 7.10 & -0.07 \\
\hline Cedar River near Austin, Minn. & 05457000 & 2007 & 10.29 & 9.58 & 9.59 & 10.30 & 0.05 \\
\hline Cedar River near Austin, Minn. & 05457000 & 2008 & 6.48 & 6.61 & 6.23 & 6.00 & -0.07 \\
\hline Cedar River near Austin, Minn. & 05457000 & 2009 & 5.23 & 4.54 & 4.65 & 4.40 & -0.08 \\
\hline Cedar River near Austin, Minn. & 05457000 & 2010 & 9.22 & 8.61 & 8.57 & 7.85 & -0.11 \\
\hline Minimum & NA & NA & 0.30 & 0.32 & 0.30 & 0.05 & -0.96 \\
\hline Maximum & NA & NA & 12.45 & 13.13 & 12.80 & 13.71 & 2.95 \\
\hline
\end{tabular}

a Rutledge (1998).

bSloto and Crouse (1996).

'The relative error is the SWB potential recharge estimate to the mean of the three different base-flow estimates (equation 7). 


\section{Appendix 3. Annual Mean Potential Recharge Estimates, 1996-2010}

This section presents the annual mean potential recharge maps for each year from 1996 through 2010 (figs. 3-1 through 3-15). As mentioned within the section "Annual Mean Potential Recharge Estimates," the mean annual potential recharge estimate for the period 1996-2010 (fig. 9) is the best estimate of potential recharge. Although the annual mean potential recharge maps are useful for comparing years with high recharge rates to years with low recharge rates, these maps should only be used as a guide for the range of potential recharge values because of to the lag-time issue explained in the report. 


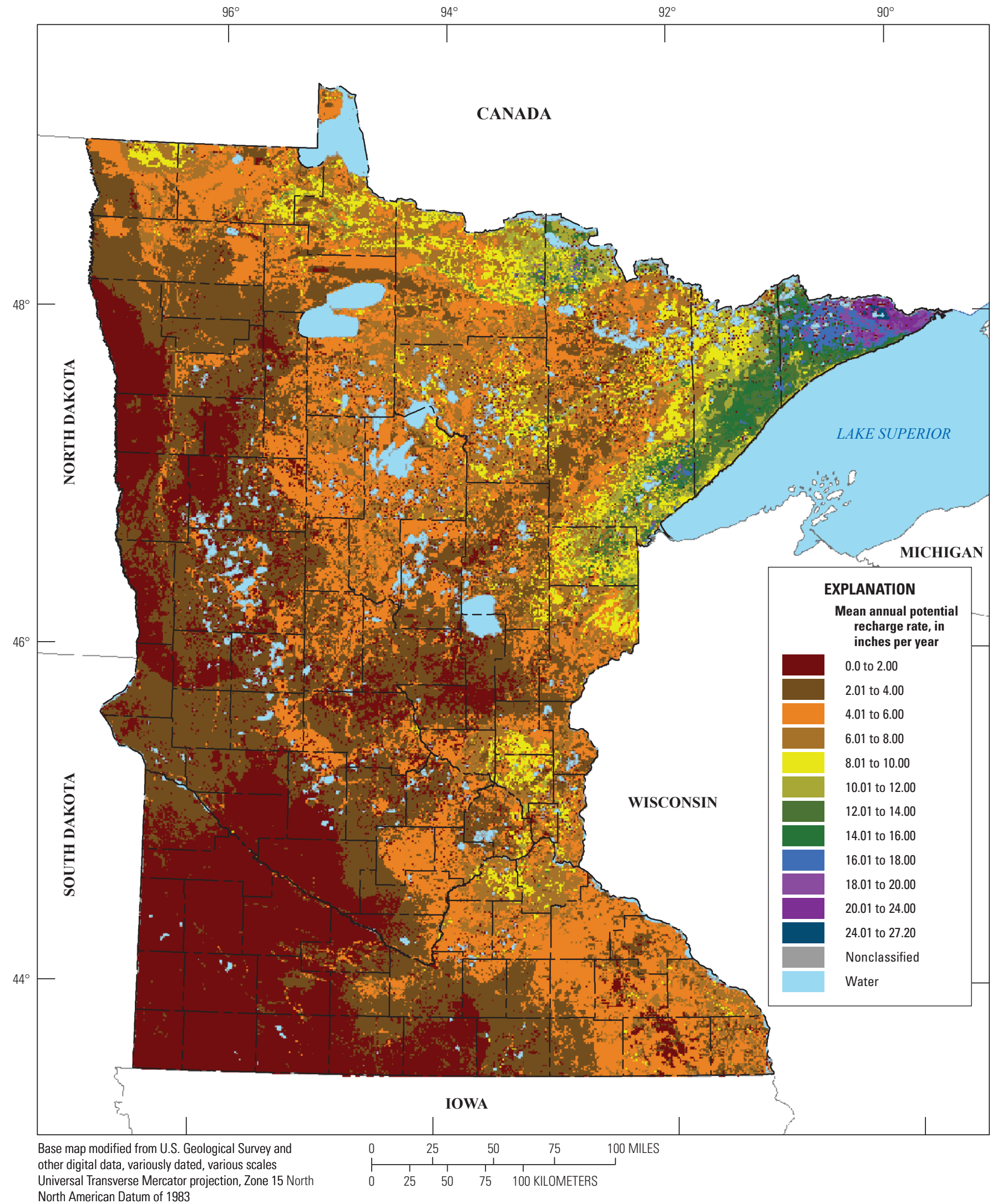

Figure 3-1. Annual mean potential recharge for 1996, based on results from the Minnesota Soil-Water-Balance (SWB) model. 


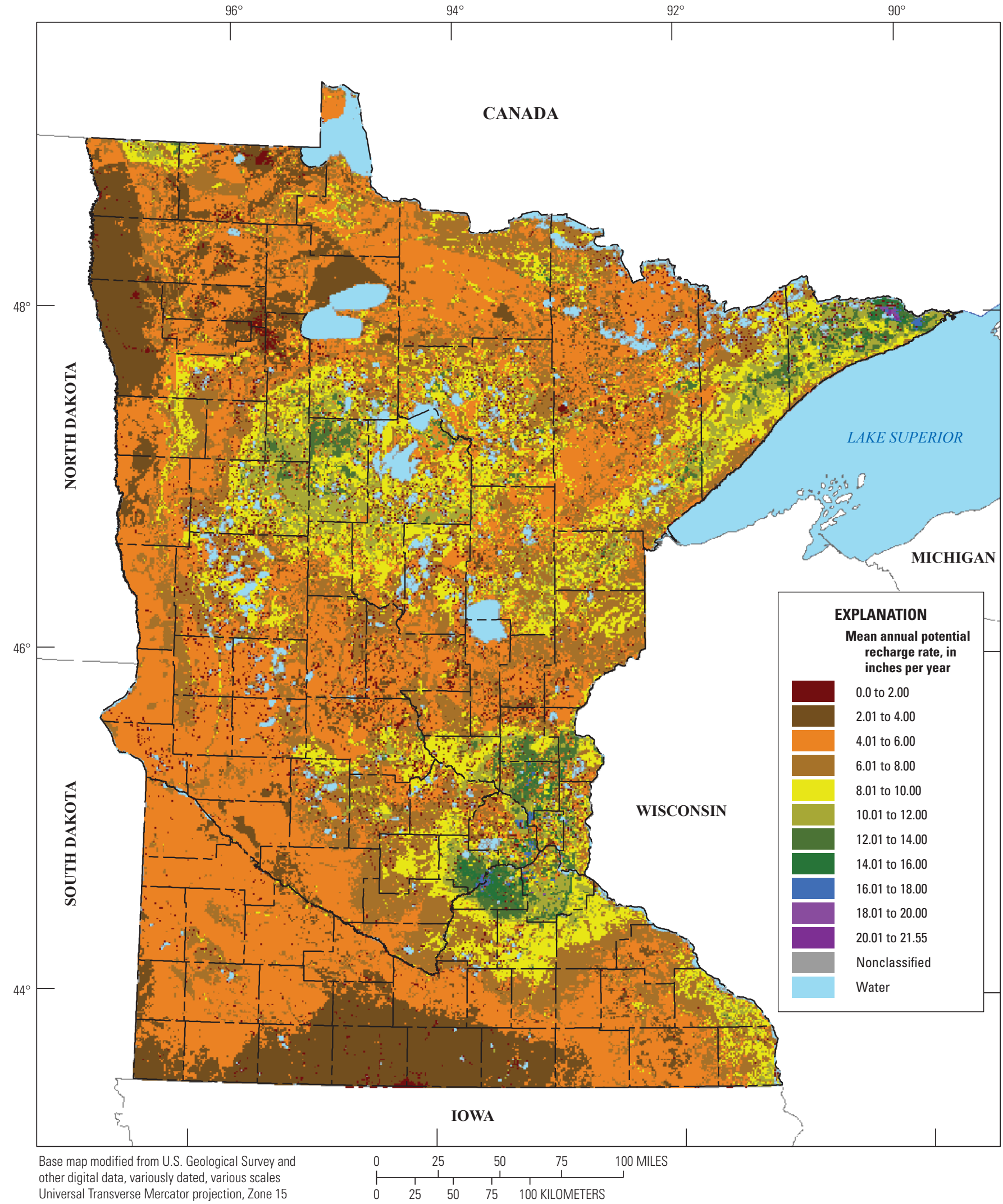

Universal Transverse Mercator projection, Zone 15 North American Datum of 1983

Figure 3-2. Annual mean potential recharge for 1997, based on results from the Minnesota Soil-Water-Balance (SWB) model. 


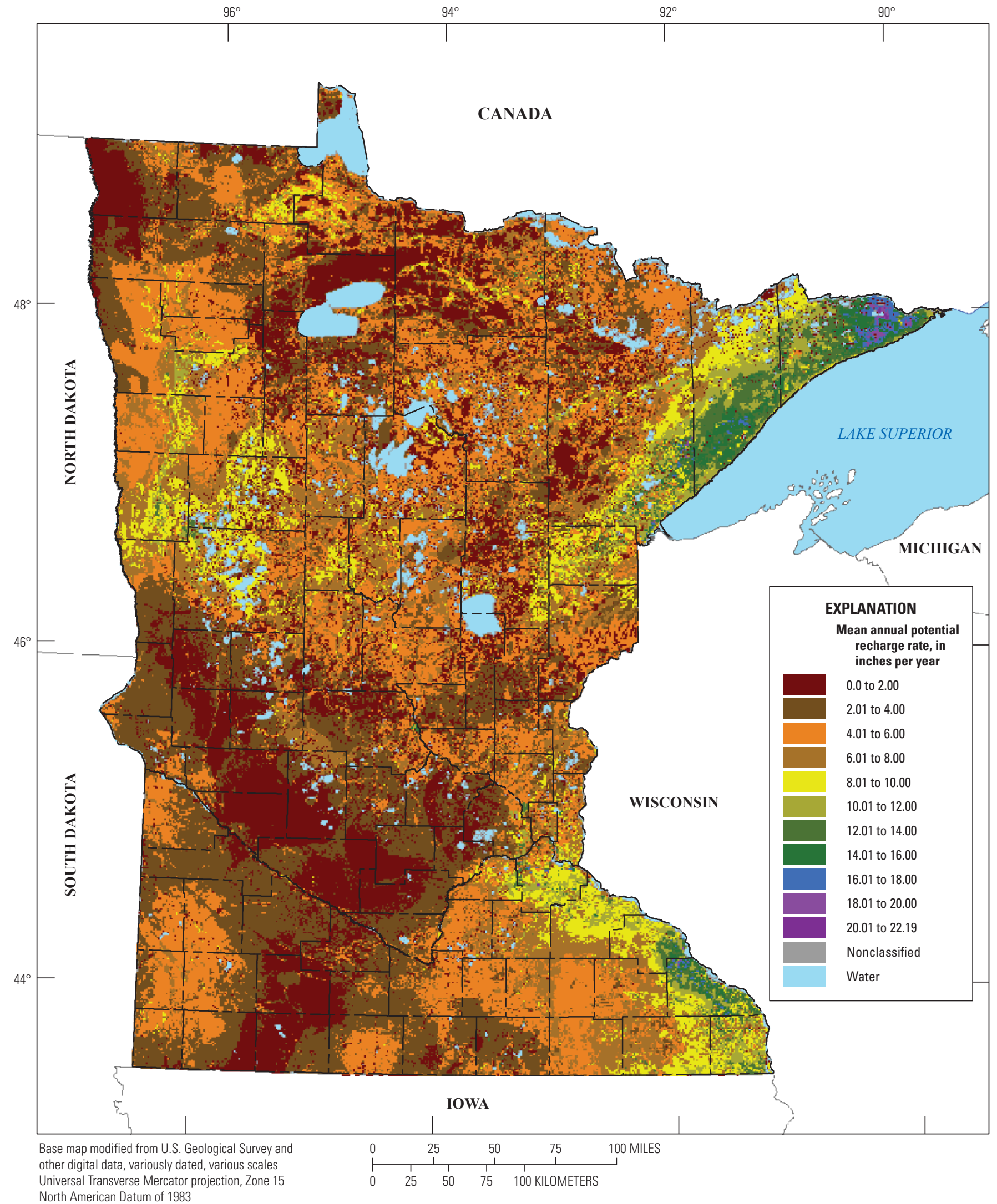

Figure 3-3. Annual mean potential recharge for 1998, based on results from the Minnesota Soil-Water-Balance (SWB) model. 


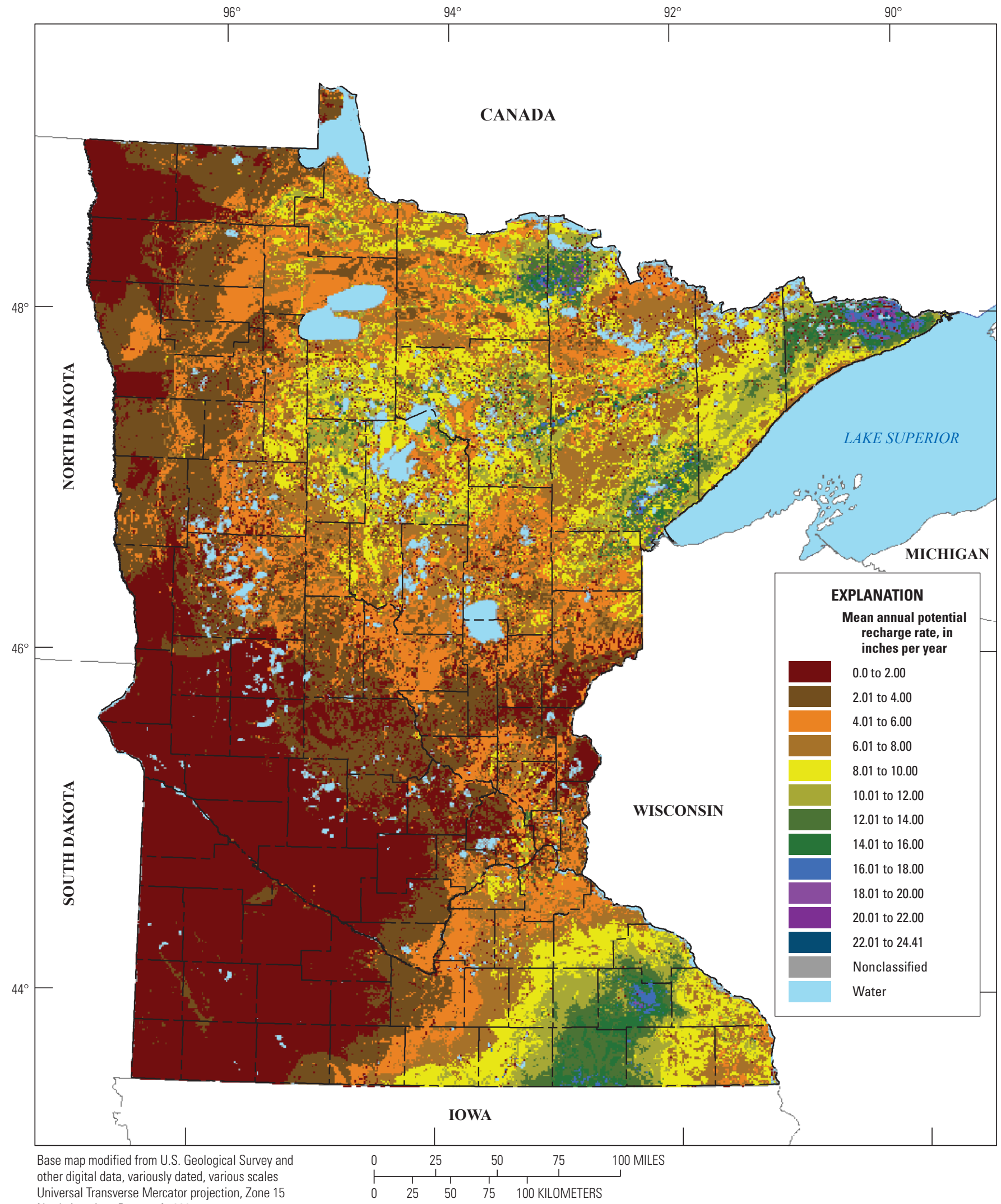

North American Datum of 1983

Figure 3-4. Annual mean potential recharge for 1999, based on results from the Minnesota Soil-Water-Balance (SWB) model. 


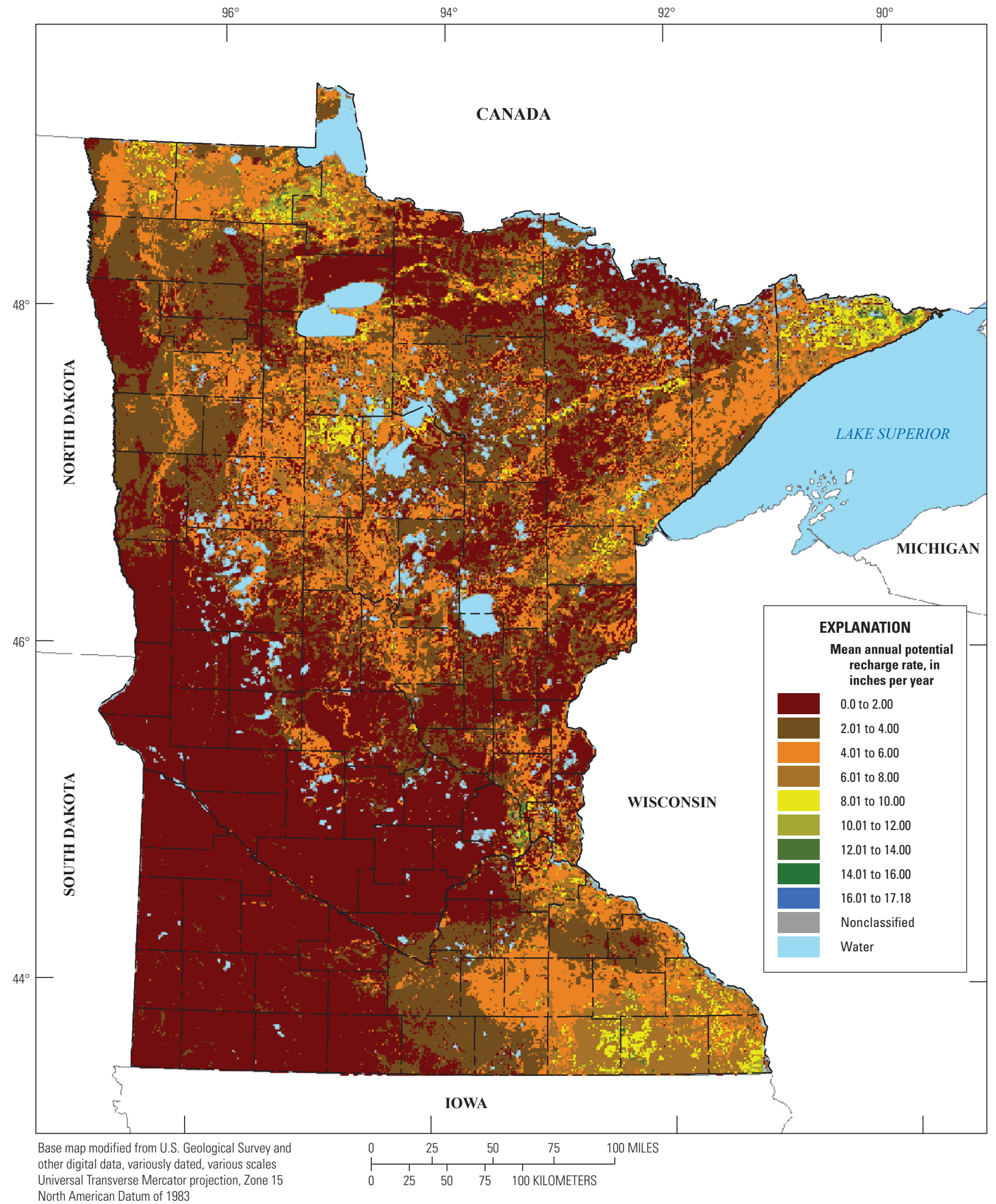

Figure 3-5. Annual mean potential recharge for 2000, based on results from the Minnesota Soil-Water-Balance (SWB) model. 


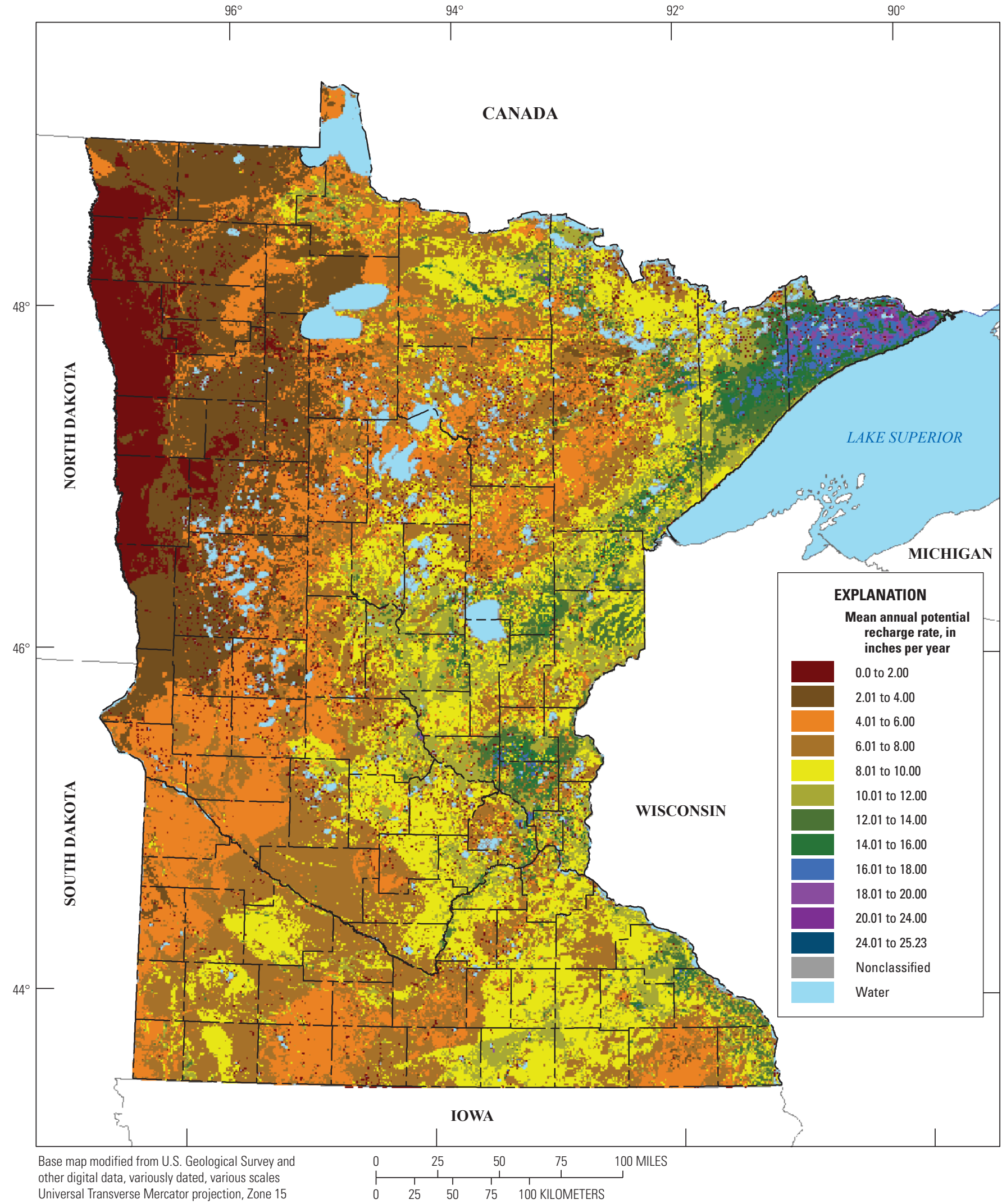

Universal Transverse Mercator projection, Zone 15 North American Datum of 1983

Figure 3-6. Annual mean potential recharge for 2001, based on results from the Minnesota Soil-Water-Balance (SWB) model. 


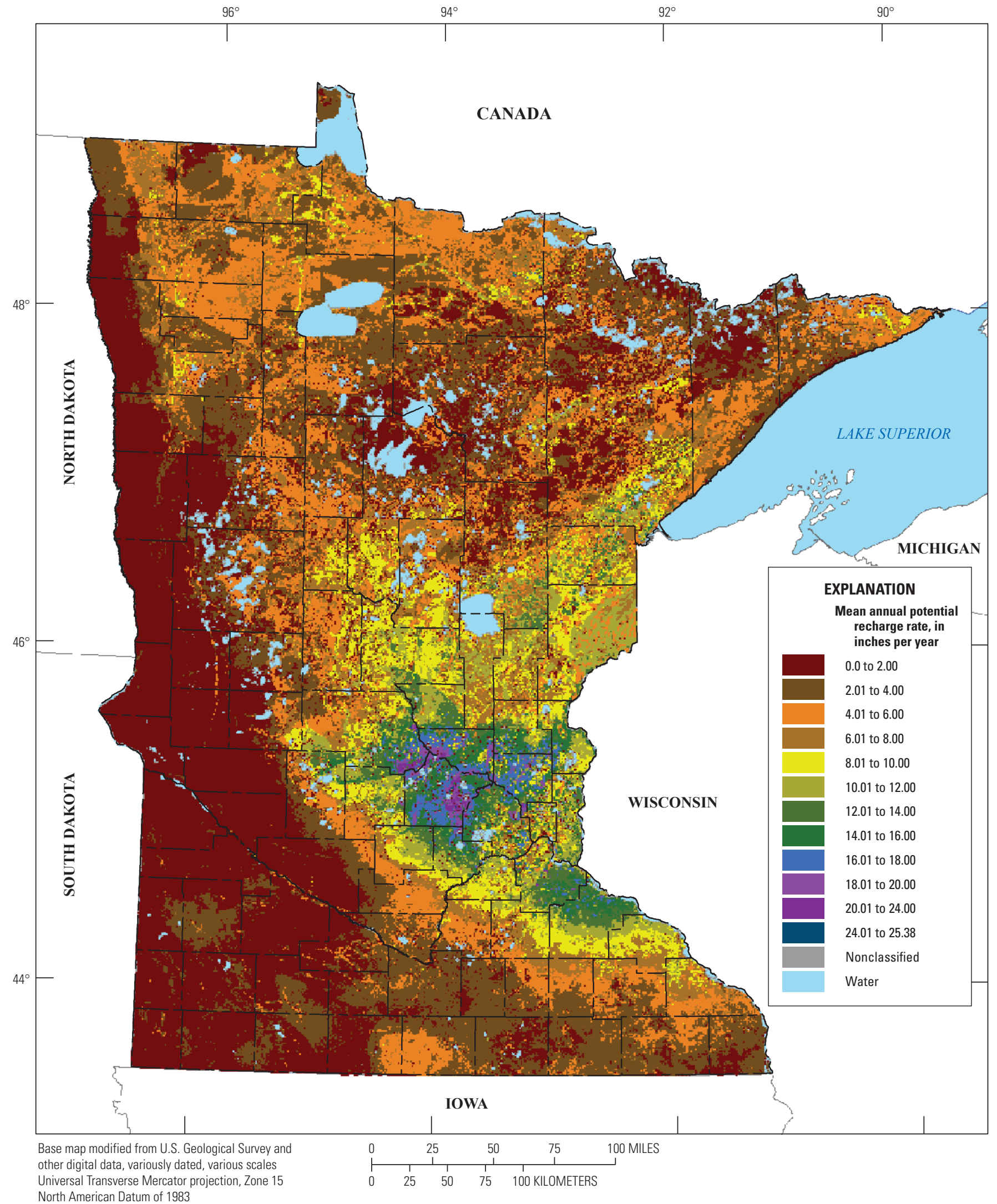

Figure 3-7. Annual mean potential recharge for 2002, based on results from the Minnesota Soil-Water-Balance (SWB) model. 


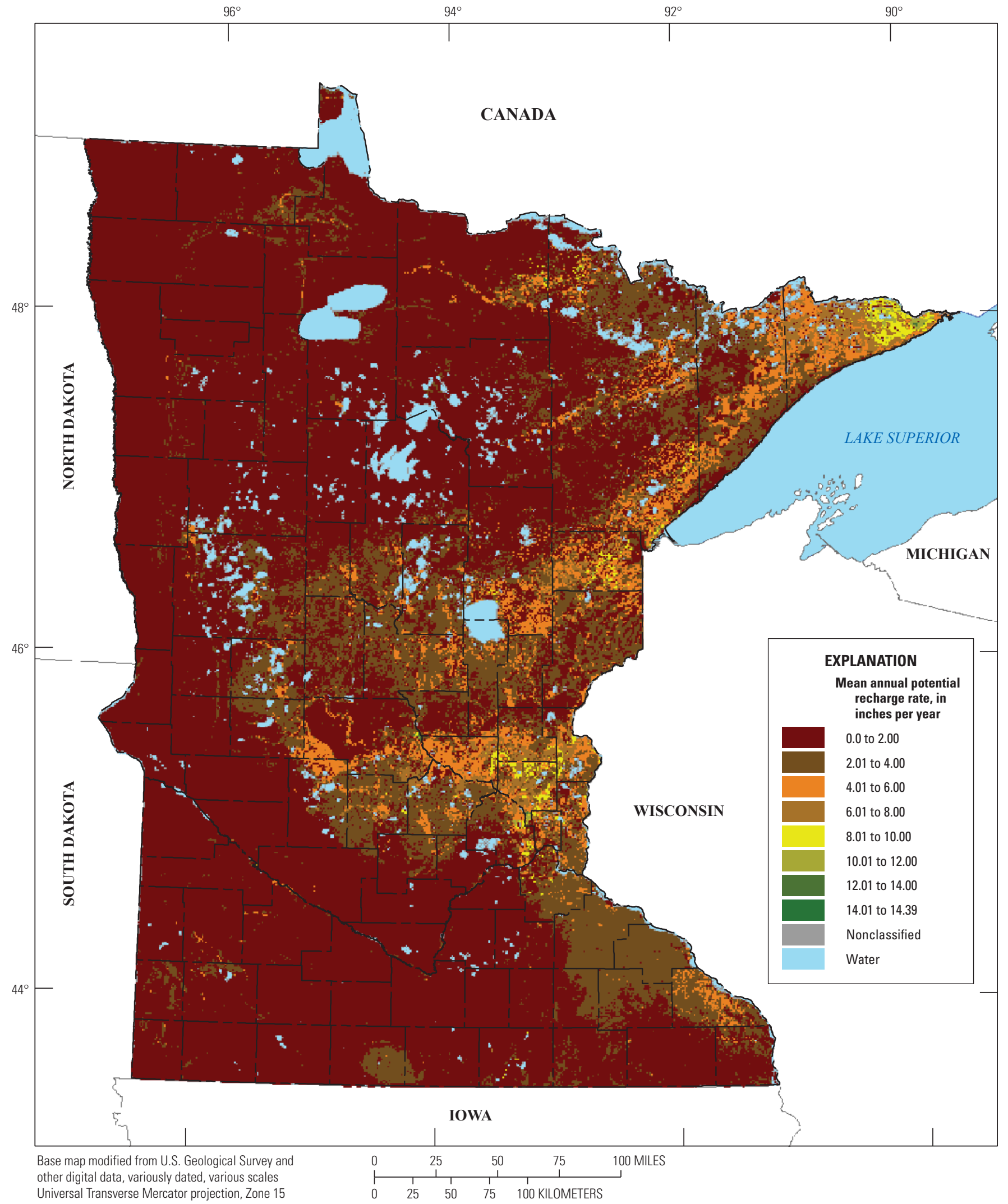

Universal Transverse Mercator projection, Zone 15 North American Datum of 1983

Figure 3-8. Annual mean potential recharge for 2003, based on results from the Minnesota Soil-Water-Balance (SWB) model. 


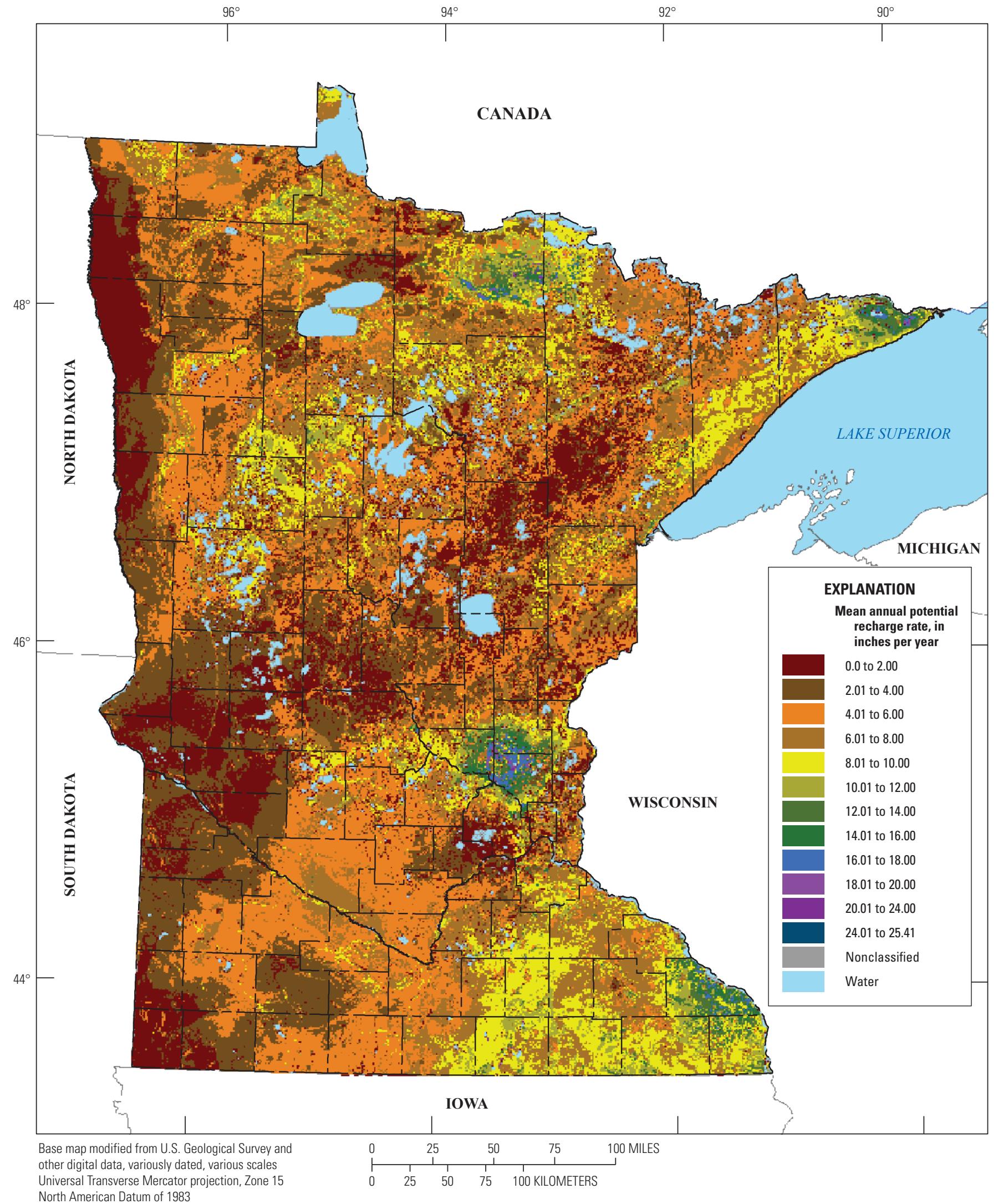

Figure 3-9. Annual mean potential recharge for 2004, based on results from the Minnesota Soil-Water-Balance (SWB) model. 


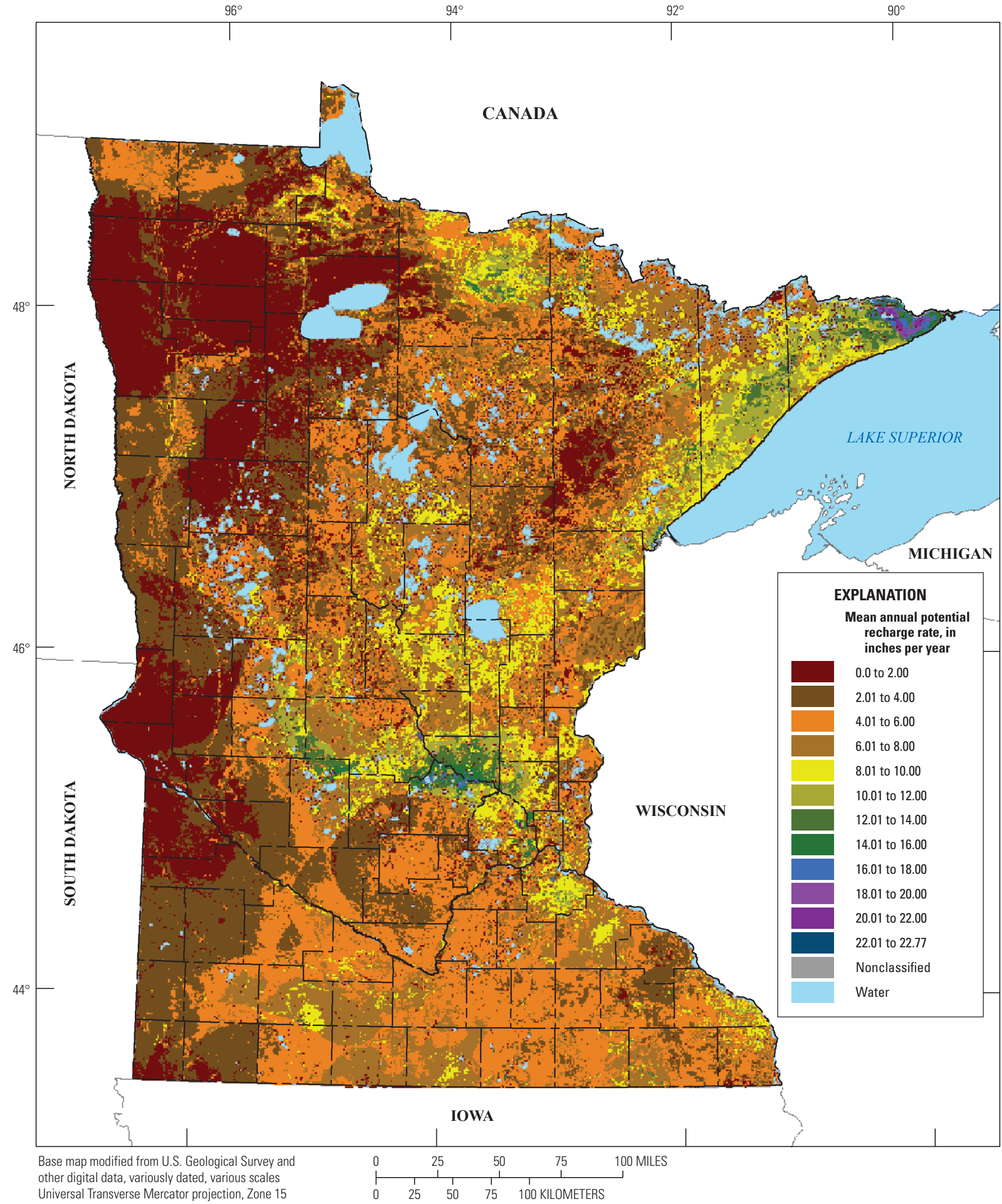

Universal Transverse Mercator projection, Zone 15 North American Datum of 1983

Figure 3-10. Annual mean potential recharge for 2005, based on results from the Minnesota Soil-Water-Balance (SWB) model. 


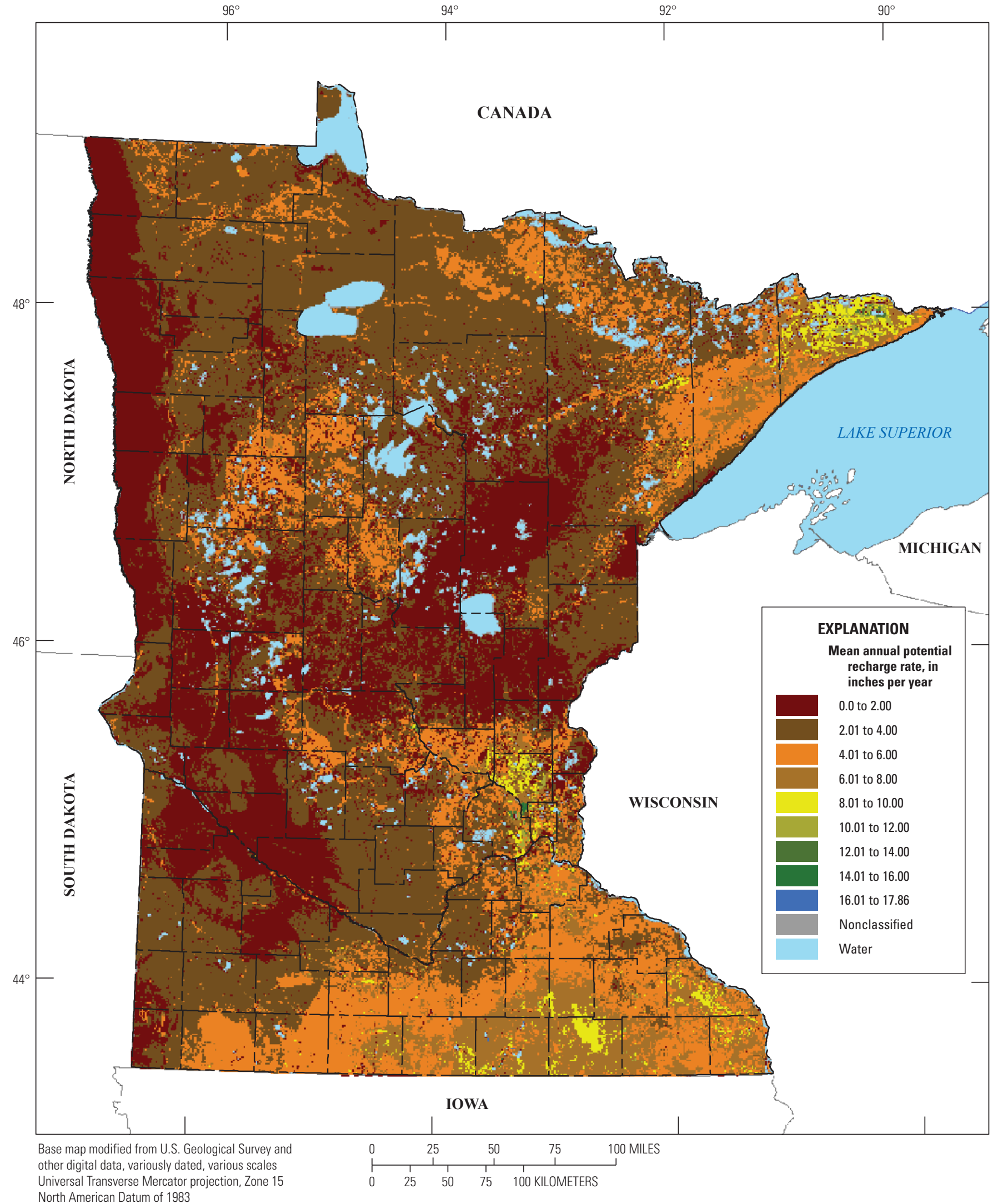

Figure 3-11. Annual mean potential recharge for 2006, based on results from the Minnesota Soil-Water-Balance (SWB) model. 


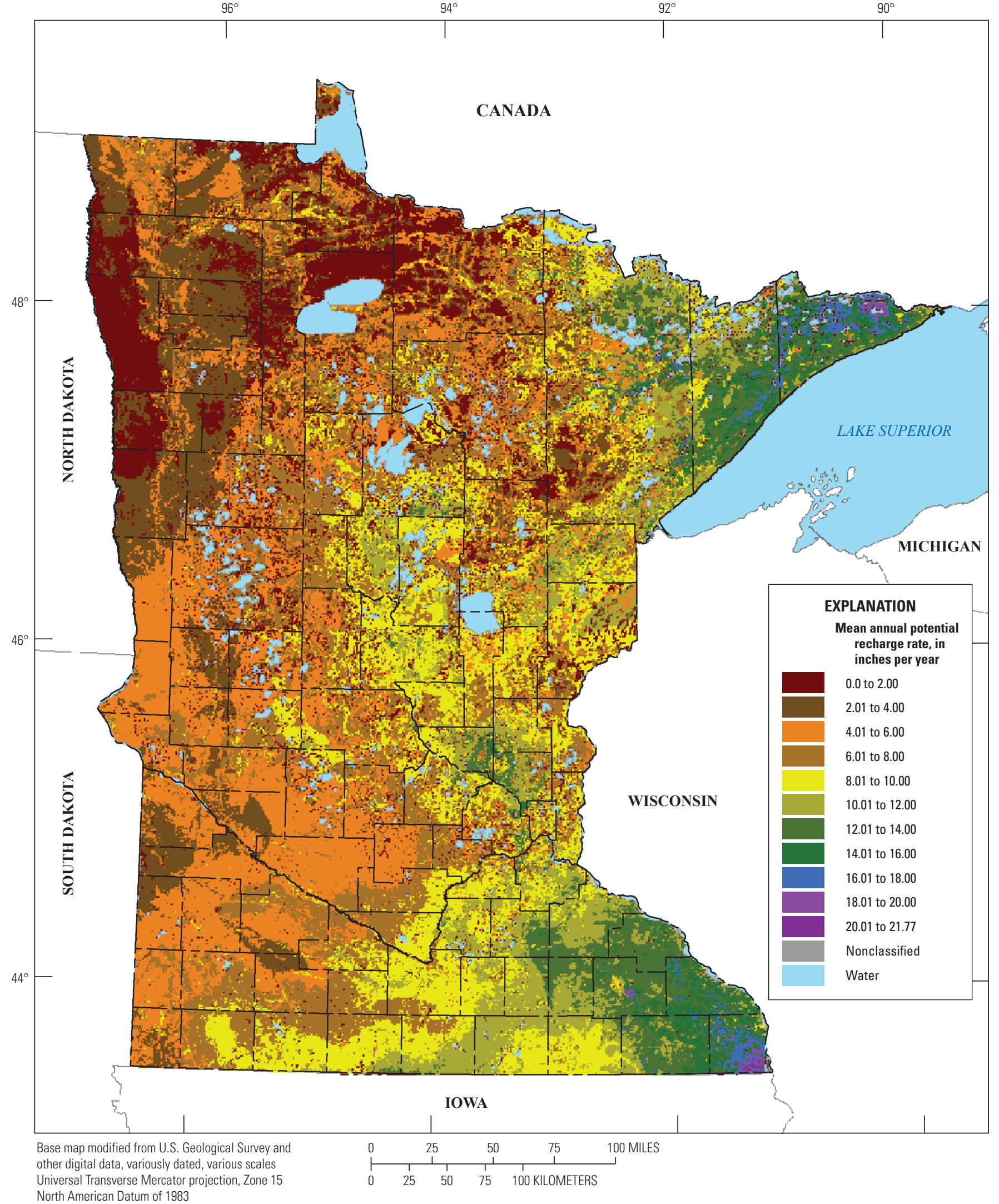

Figure 3-12. Annual mean potential recharge for 2007, based on results from the Minnesota Soil-Water-Balance (SWB) model. 


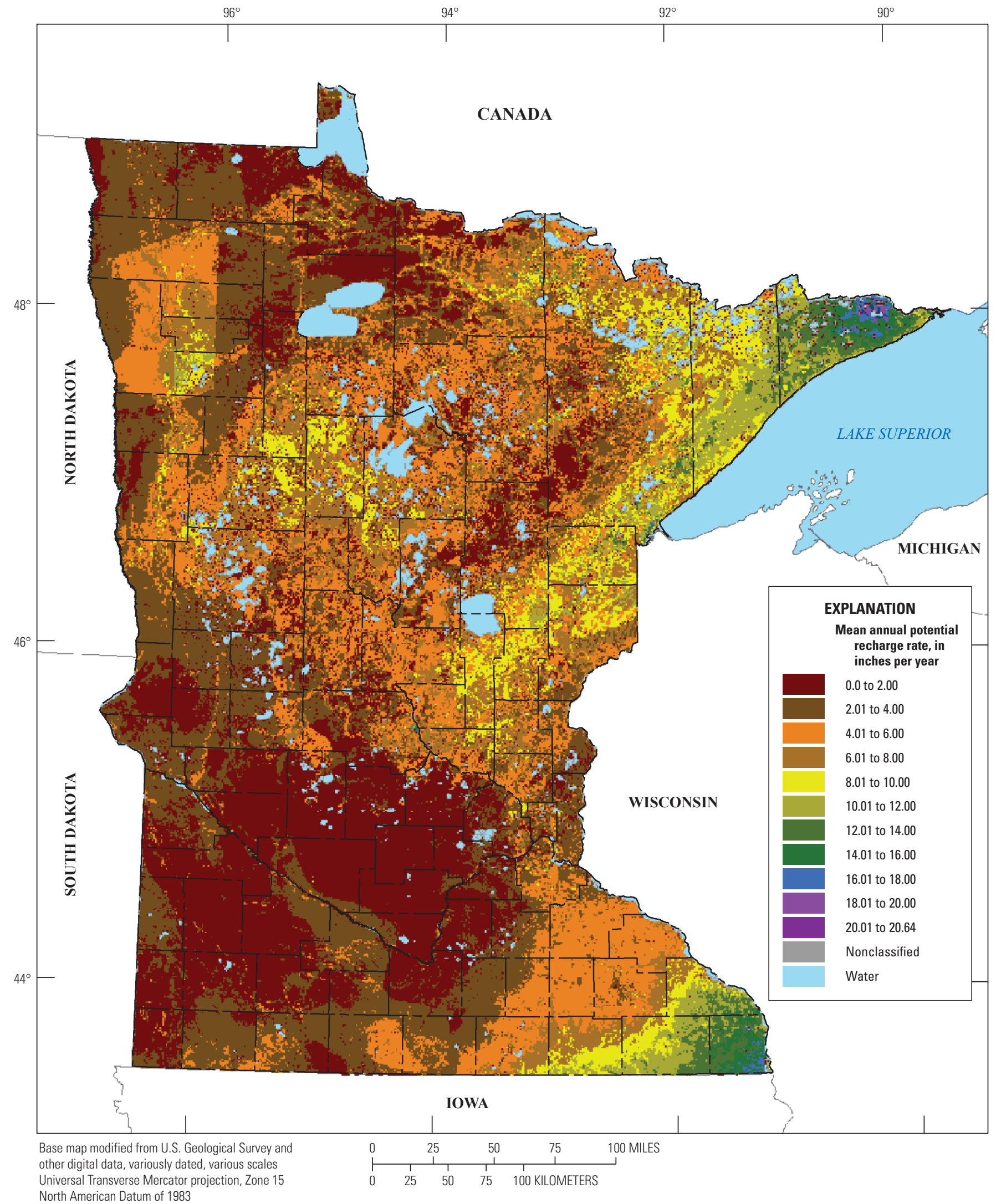

Figure 3-13. Annual mean potential recharge for 2008, based on results from the Minnesota Soil-Water-Balance (SWB) model. 


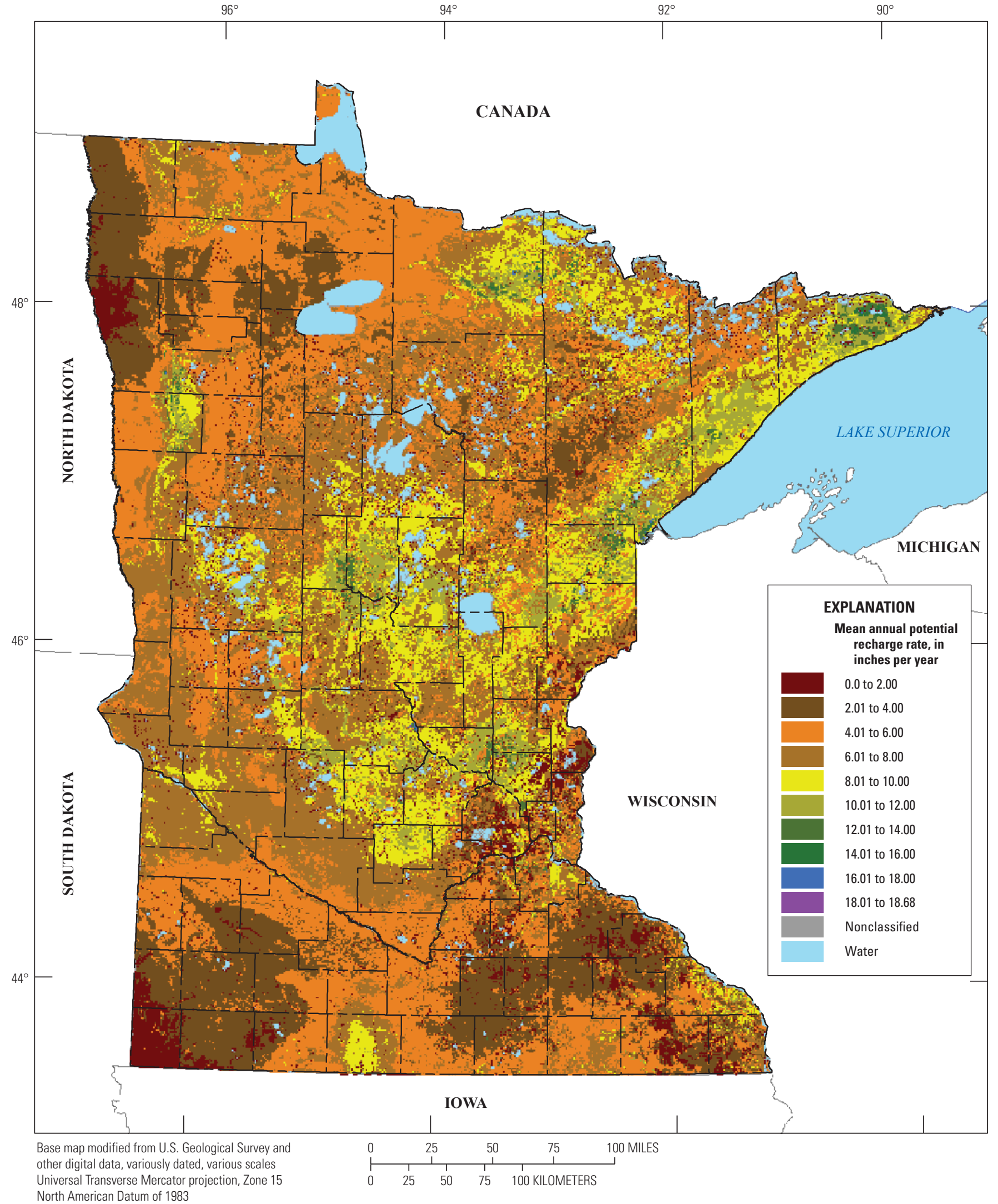

Figure 3-14. Annual mean potential recharge for 2009, based on results from the Minnesota Soil-Water-Balance (SWB) model. 


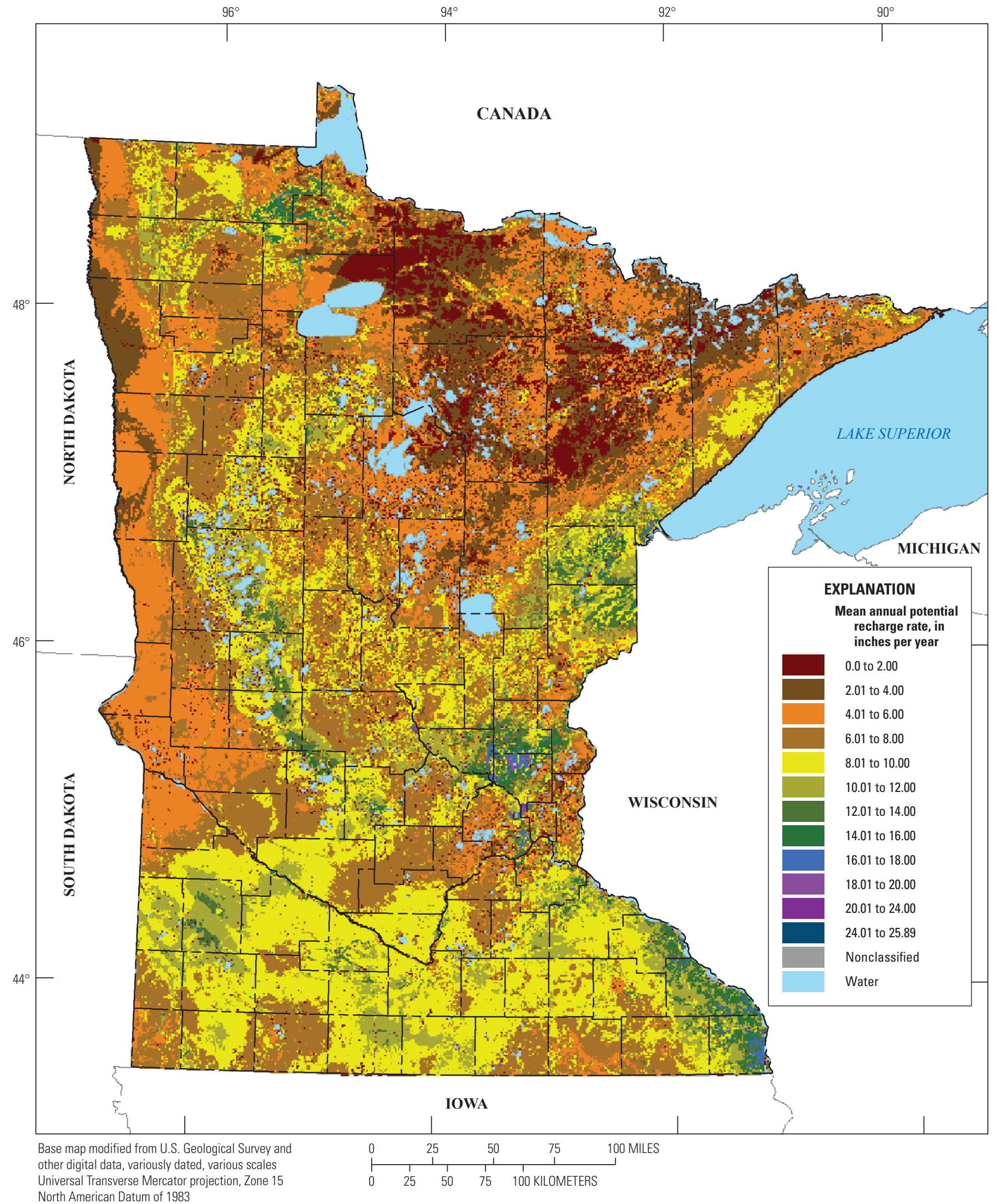

Figure 3-15. Annual mean potential recharge for 2010, based on results from the Minnesota Soil-Water-Balance (SWB) model. 


\section{Appendix 4. Regional Regression Recharge, 1971-2000}

This section presents figure 4-1, which reproduces the Delin and others (2007) mean annual recharge rates to surficial materials, from 1971 through 2000, for the State of Minnesota.

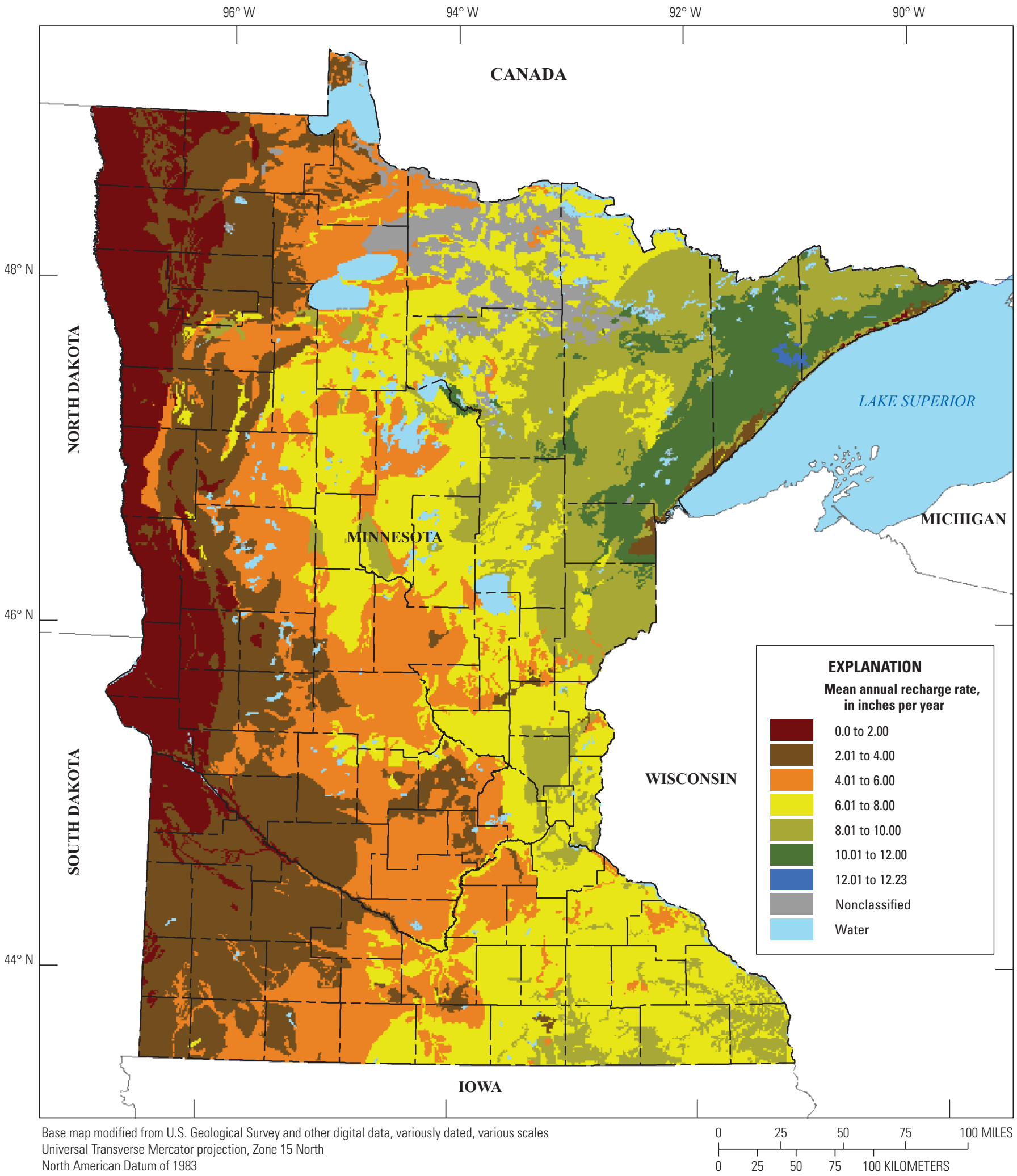

Figure 4-1. Mean annual recharge rates to surficial materials in Minnesota from 1971-2000 based on the regional regression recharge model of Delin and others (2007). 
Publishing support provided by the: Rolla Publishing Service Center

For more information concerning this publication, contact: Director, USGS Minnesota Water Science Center 2280 Woodale Drive

Mounds View, Minnesota 55112

(763) 783-3100

Or visit the Minnesota Water Science Center Web site at: http://mn.water.usgs.gov/ 



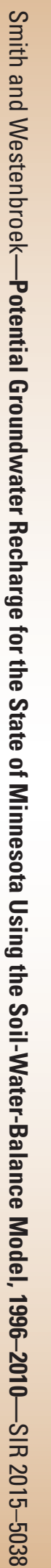

